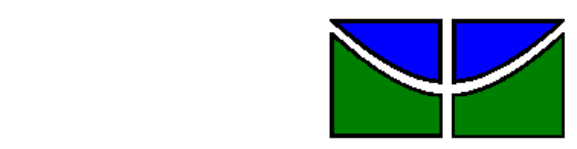

Universidade de Brasília

Faculdade de Economia, Administração e Contabilidade

Departamento de Administração

\title{
WILLIAM MARQUES
}

\section{Terminal de Carga do Aeroporto Internacional de Brasília}

$$
\text { Brasília - DF }
$$




\title{
WILLIAM MARQUES
}

\section{Terminal de Carga do Aeroporto Internacional de Brasília}

\author{
Monografia apresentada ao Departamento \\ de Administração como requisito parcial à \\ obtenção do título de Bacharel em \\ Administração.
}

Professor Orientador: MSc, Evaldo Cesar Cavalcante Rodrigues

Brasília - DF 
Marques, William.

Terminal de Carga do Aeroporto Internacional de Brasília / William Marques. - Brasília, 2010.

101f. : il.

Monografia (bacharelado) - Universidade de Brasília, Departamento de Administração, 2010.

Orientador: Prof. Msc., Evaldo César Cavalcante Rodrigues, Departamento de Administração.

1. Aeroportos. 2. Transporte Aéreo. 3. Carga Aérea 3. Logística Empresarial. 5. Infraestrutura Aeroportuária. I. Título. 


\title{
Terminal de Carga do Aeroporto Internacional de Brasília
}

\begin{abstract}
A Comissão Examinadora, abaixo identificada, aprova o Trabalho de Conclusão do Curso de Administração da Universidade de Brasília do aluno
\end{abstract}

\section{William Marques}

Msc., Evaldo César Cavalcante Rodrigues

Professor-Orientador

Dr., Rildo Ribeiro dos Santos

Professor-Examinador
Msc., Karla Inez Leitão Lundgren

Professor-Examinador

Brasília-DF, 08 de setembro de 2010. 
Dedico este trabalho a minha querida esposa Karina Fernandes Gomes Marques, pelo apoio e amor dedicados nestes anos de caminhada. 


\section{AGRADECIMENTOS}

Agradeço a Jesus Cristo em primeiro lugar, pelo exemplo de vida e inspiração, e todos os meus familiares, em especial a Lazinha Alves da Silva (in memorian). Aos colegas da Logística de Carga do Aeroporto de Brasília pelos ensinamentos transmitidos e disposição em ajudar; aos professores e orientadores do PPGT da Universidade de Brasília que tanto contribuíram à presente pesquisa, e aos amigos de sempre. 


\section{RESUMO}

A infraestrutura aeroportuária brasileira é de suma importância para o desenvolvimento econômico e social do país. Alvo de investimento nas próximas décadas pelo Governo Federal e pela Empresa Brasileira de Infraestrutura Aeroportuária (INFRAERO), os aeroportos brasileiros se tornarão mais eficientes e competitivos no mercado mundial, tanto no atendimento da demanda por passageiros quanto de cargas. O AIB-PJK desempenha papel importante no cenário nacional, estando entre os primeiros na movimentação de aeronaves, pessoas e cargas, fazendo parte dos aeroportos das cidades que sediarão a Copa do Mundo de Futebol da FIFA. Cada vez mais expressiva é participação do transporte aéreo de carga no comércio exterior e doméstico brasileiro, sendo necessário avaliar quais as prioridades de investimento, de maneira a evitar futuros gargalos logísticos, adequando e modernizando os Terminais de Carga às exigências do mercado mundial e nacional. Para atingir esse objetivo foi utilizada uma abordagem de pesquisa mista, pelo método exploratório quantitativo-qualitativo e pesquisa descritiva qualitativa. Foram coletados dados secundários junto a órgãos e organismos nacionais e internacionais, relacionados ao comercio exterior, transporte de carga aérea e logística; e pesquisas bibliográficas - principalmente livros na área de logística e transporte, anuários estatísticos, trabalhos acadêmicos, artigos e periódicos especializados. Ao se analisar os aspectos financeiros da logística de carga aérea de Brasília e os investimentos previstos em torno de $\mathrm{R} \$ 133$ milhões, o retorno seria muito demorado e inviável em termos econômicos no curto e médio prazo. Mas pensando-se num horizonte de 20 a 30 anos, nas expectativas de crescimento da economia brasileira, do aumento da renda per capita brasiliense, da exposição do Brasil pelos mega-eventos futuros, e exaustão a médio prazo do terminal, justificam-se tais empreendimentos.

1. Aeroportos. 2. Transporte Aéreo. 3. Carga Aérea 3. Logística Empresarial. 5. Infraestrutura Aeroportuária. 


\section{LISTA DE ILUSTRAÇÕES}

Figura 1: Comparação entre os diversos modais de transporte 26

Figura 2 - Comparativo entre as infraestrutura de transporte: BrasilxEUA. ...... 28

Figura 3 - Tráfego aéreo mundial em 24 horas

Figura 4 - Fluxograma da Importação na rede INFRAERO

Figura 5 - Fluxograma da Exportação na rede INFRAERO 50

Figura 6 - Elos que compõem a Aviação Civil Brasileira. 54

Figura 7 - Mapa da rede de aeroportos INFRAERO. 55

Figura 8 - Demanda histórica de passageiros no Brasil. 56

Figura 9 - Imagem aérea do sítio aeroportuário de Brasília. 60

Figura 10 - Evolução do preço da passagem aérea no Brasil. 61

Figura 11 - Evolução da carga no SBBR. 65

Figura 12 - Capacidade operacional dos TECAs da rede INFRAERO 65

Figura 13 - Projeçao da reforma e amplianção do SBBR 66

Figura 14 - Malha aérea brasileira - rotas regulares. 68

Figura 15 - Valor das arrecadações e isenções no SBBR: 2006 à 2009. 69

Figura 16 - Evolução agrupada da carga no SBBR 71

Figura 17 - Evolução das receitas da carga doméstica na rede INFRAERO . 75

Figura 18 - Evolução por peso da carga doméstica na rede INFRAERO. 75 


\section{LISTA DE TABELAS}

Tabela 1 - Características de algumas aeronaves transportadoras de cargas........25

Tabela 2 - Infraestrutura Aeroportuária Brasileira.........................................51

Tabela 3 - Os dez maiores em movimento de passageiros em $2009 \ldots \ldots \ldots \ldots \ldots \ldots . . . .64$

Tabela 4 - Os dez Maiores em movimento de carga em 2009 ...........................64

Tabela 5 - Capacidade operacional dos aeroportos em horários de pico...............67

Tabela 6 - Movimento de cargas pelas Cias Aéreas no SBBR em kg ...................68

Tabela 7 - Movimento de aeronaves cargueiras - 10 maiores da Rede ................69

Tabela 8 - Os vinte maiores importadores do DF em 2009 no SBBR ...................70

Tabela 9 - Evolução da carga importada no TECA-BR com ATAERO ..................71

Tabela 10 - Cargas em perdimento. Dez maiores em $\mathrm{n}^{\circ}$ processos $\ldots \ldots \ldots \ldots \ldots \ldots \ldots . \ldots . \ldots \ldots$

Tabela 11 - Evolução da carga exportada - TECA-BR com ATAERO ...................73

Tabela 12 - Exportações no Distrito Federal: 2006 à 2009 ..............................74

Tabela 13 - Evolução da Carga doméstica - TECA-BR com ATAERO ..................76

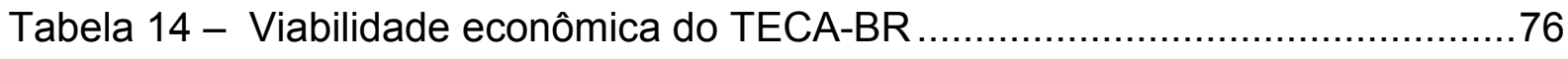

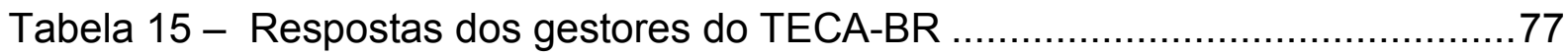




\section{LISTA DE ABREVIATURAS E SIGLAS}

ACI: Airports Council International

AIB-PJK: Aeroporto Internacional de Brasília Juscelino Kubitschek

ANAC: Agência Nacional de Aviação Civil

ANSI: Instituto Nacional Americano para Padronizações

BNDES: Banco Nacional de Desenvolvimento Econômico e Social

BRLC: Gerência de Logística de Carga

DRP: Planejamento das Necessidades de Distribuição

DTA: Documento de Trânsito Aduaneiro

EDI: Intercâmbio Eletrônico de Dados

ERP: Planejamento dos Recursos Materiais ou Enterprise Resource Planning FGV/CPDOC: Fundação Getúlio Vargas/Centro de Pesquisa e Documentação

GIS: Sistemas de Informações Geográficas ou SIG

GPS: Sistema de Posicionamento Global ou SPG

HAWB: House Air Waybill conhecimento aéreo de carga desconsolidada

ICAO: International Civil Aviation Organization

INFRAERO: Empresa Brasileira de Infraestrutura Aeroportuária

Lead Time: Tempo de aprovisionamento ou abastecimento

MANTRA: Sistema de Gerenciamento e Manifesto de Carga

MAWB: Master Air Waybill ou conhecimento aéreo

MDIC: Ministério do Desenvolvimento, Indústria e Comércio

MRP: Planejamento das Necessidades de Materiais ou PNM

PAX: Passageiro

PPCP: Planejamento, Programação e Controle da Produção

RFID: Identificação por rádio freqüência

SBBR: Aeroporto Internacional Juscelino Kubitschek - Brasília/DF

SBCF: Aeroporto Internacional Tancredo Neves - Confins/Belo Horizonte 
SBCT: Aeroporto Internacional Afonso Pena -São José dos Pinhais/Curitiba

SBEG: Aeroporto Internacional Eduardo Gomes - Manaus/AM

SBFL: Aeroporto Internacional Hercílio Luz - Florianópolis/SC

SBFZ: Aeroporto Internacional Pinto Martins - Fortaleza/CE

SBGL: Aeroporto Internacional Antônio Carlos Jobim (Galeão) - Rio De Janeiro/RJ

SBGO: Aeroporto Santa Genoveva - Goiânia-/GO

SBGR: Aeroporto Internacional de Guarulhos - São Paulo/SP

SBKP: Aeroporto Internacional de Viracopos - Campinas/São Paulo-SP

SBNT: Aeroporto Internacional Augusto Severo - Natal/RN

SBPA: Aeroporto Internacional Salgado Filho - Porto Alegre / Canoas

SBRF: Aeroporto Internacional dos Guararapes - Recife/PE

SBRJ: Aeroporto Santos Dumont - Rio De Janeiro/RJ

SBSP: Aeroporto de Congonhas - São Paulo/SP

SBSV: Aeroporto Internacional Luís Eduardo Magalhães - Salvador/BA

SBVT: Aeroporto Eurico de Aguiar Salles - Vitória/ES

SGA: Sistema de Gerenciamento de Armazéns ou WMS

SGP: Sistema de Gerenciamento de Pedidos

SGT: Sistema de Gerenciamento de Transportes

SIL: Sistema de Informações Logísticas

SISCOMEX: Sistemas Integrados de Comércio Exterior

SRCO: Superintendência Regional do Centro Oeste

SRF: Secretaria da Receita Federal

TECA: Terminal de Carga ou TECAs no plural.

TECA-BR: Terminal de Carga do Aeroporto Internacional de Brasília TECAPLUS - Sistema de Gerenciamento de Carga da INFRAERO

TI: Tecnologia de Informação

TIACA: International Air Cargo Association

TPS: Terminal de Passageiros 


\section{SUMÁRIO}

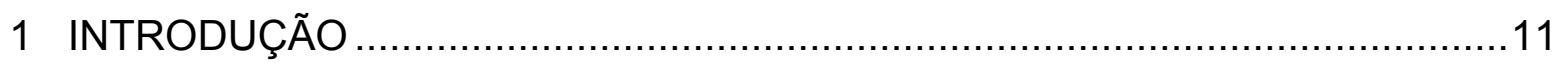

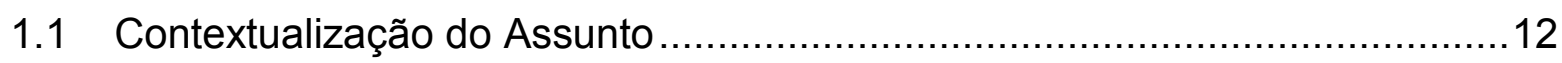

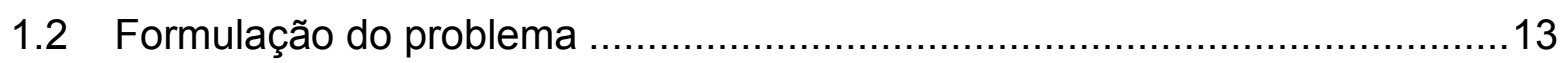

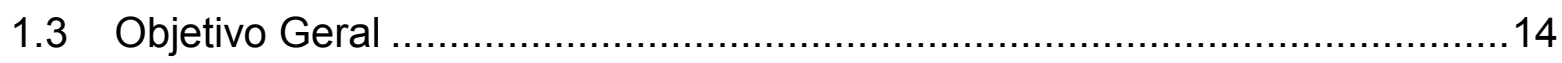

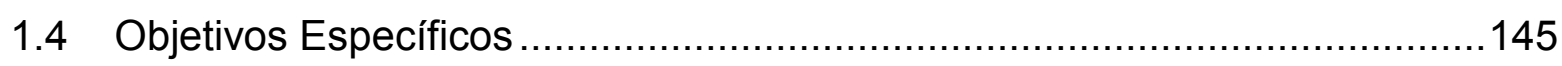

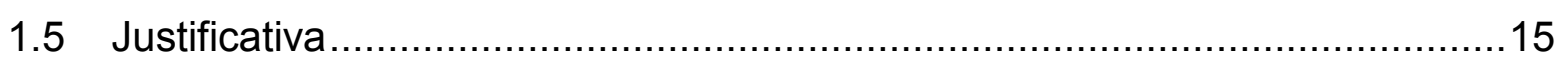

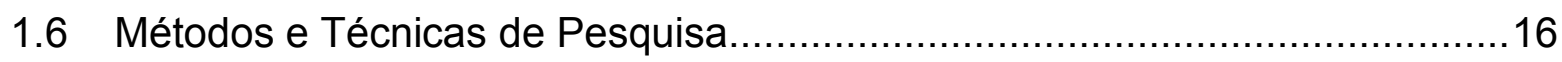

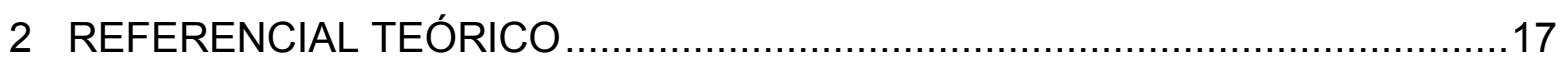

2.1 Gestão da Produção/Operações ............................................................17

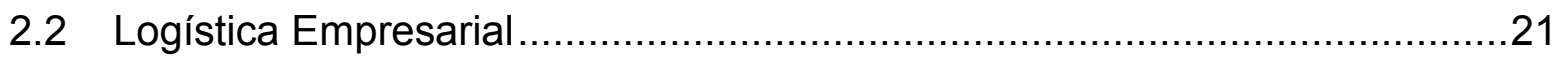

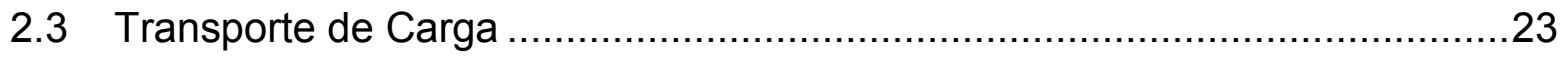

2.4 Transporte de Carga Aérea Internacional ..............................................28

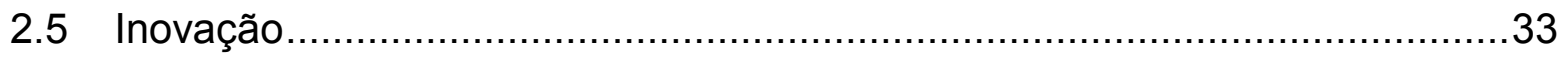

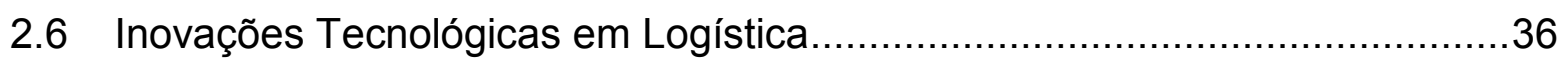

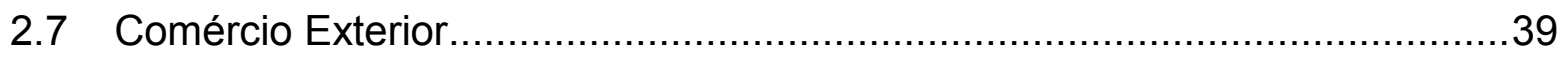

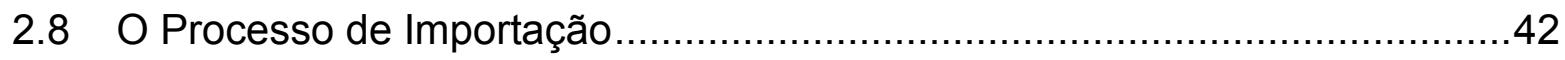

2.9 O Processo de Exportação ……….......................................................

2.10 Administração dos Aeroportos Brasileiros.................................................51

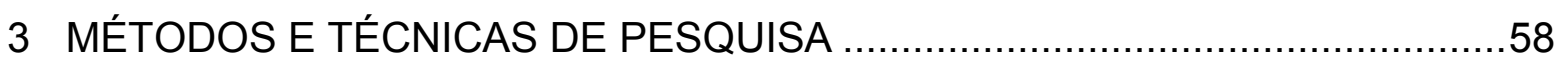

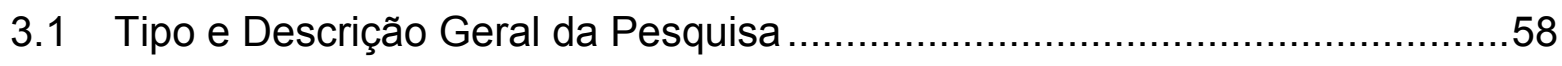

3.2 Caracterização do Setor de Cargas do Aeroporto de Brasília........................59

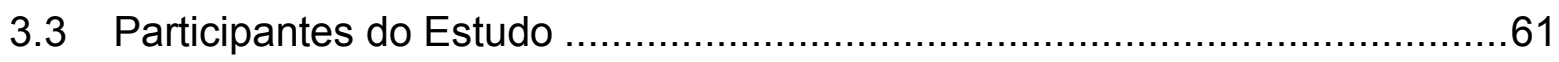

3.4 Caracterização dos Instrumentos de Pesquisa ............................................61

3.5 Procedimento de Coleta e Análise dos Dados ............................................62 
4 RESULTADOS E DISCUSSÃO .63

4.1 Apresentação Documental da Estrutrura Aeroportuária .63

4.2 Resultado da Pesquisa Descritiva Qualitativa 77

5 CONSIDERAÇÕES FINAIS 81

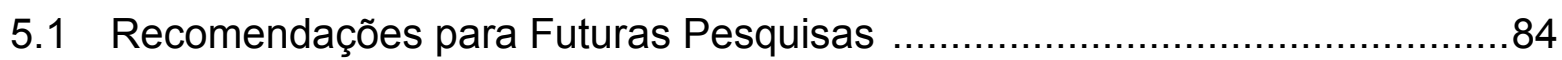

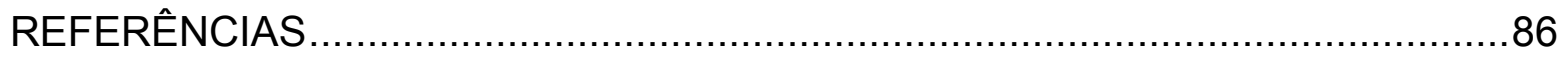

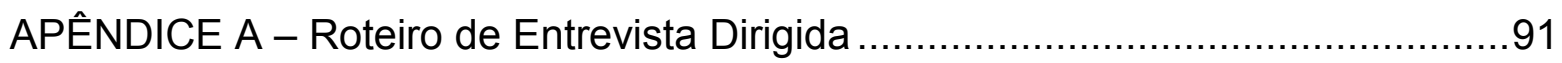
APÊNDICE B - Relação dos Respondentes da Entrevista Dirigida.........................94 APÊNDICE C - Organograma da Superintendência do AIB-PJK …………….......95 APÊNDICE D - Perspectiva Aérea da Ampliação do AIB-PJK ………...................96 ANEXO A - Tabela de Tarifas de Armazenagem ……........................................ ANEXO B - Cotação do Dólar: 2005 à 2009...................................................100 


\section{INTRODUÇÃO}

A logística de carga nos terminais aeroportuários no Brasil constitui uma importante fonte de receitas para o governo, empresas privadas e pessoas físicas. Entender a evolução do mercado de transporte aéreo e rodoviário de cargas, as variáveis e informações geradas no processo, as características dos materiais transportados e o papel dos aeroportos e recintos alfandegados, é de suma importância para a melhoria e expansão do comércio exterior e interno do país. A carga aérea vem se destacando em relação aos outros modais tradicionalmente utilizados no que se refere à velocidade no transporte de cargas, a facilidade para vencer grandes distâncias e a segurança proporcionada contra furtos e avarias.

Apesar da sua importância, o comércio da carga aérea ainda é pequeno, quando comparado aos outros modais, devido ao alto custo de utilização. Desde o despacho da carga na sua origem, até o seu recebimento nos recintos alfandegados, existem legislações e normas a serem obedecidas no que se refere ao trato da carga, às formas de tributação e uma série de processos burocráticos a serem executados pelos elos governamentais e privados envolvidos.

O papel da Empresa Brasileira de Infraestrutura Aeroportuária (INFRAERO) é fundamental nesta cadeia logística. Responsável por administrar os aeroportos brasileiros, a empresa tem como meta para o próximo quadriênio realizar investimentos expressivos na expansão dos seus Terminais de Carga (TECA), e Terminais de Passageiros (TPS). Analisando os aspectos operacionais, de infraestrutura e financeiros, é possível diagnosticar as reais necessidades de expansão dos terminais de logística, de aquisição de equipamentos e das variáveis que envolvem esses investimentos. O Aeroporto Internacional de Brasília é um caso atípico, pois se destaca como o terceiro no país em fluxo de aeronaves e passageiros numa região metropolitana com uma população em torno de apenas três milhões de habitantes, considerada pequena quando comparada a população das regiões dos outros Aeroportos líderes no mercado, nos Estados de São Paulo e Rio de Janeiro. 


\subsection{Contextualização do Assunto}

Segundo dados divulgados pela INFRAERO, aproximadamente $97 \%$ das operações de logística aérea no Brasil são realizadas por seus 34 Terminais de Logística de Carga (TECAs), sendo que 100\% da carga importada pelo modal aéreo, com exceção das cargas courier, passam necessariamente por seus armazéns. No entanto, a movimentação de carga pelos aeroportos brasileiros não se restringe ao modal aéreo, mas também são provenientes dos modais marítimo, rodoviário e dutoviário - no caso de combustíveis, chegando aos aeroportos por trânsito aduaneiro, provenientes de zonas alfandegadas primárias ou secundárias.

Analisando os últimos quatro anos podemos ter um quadro da crise econômica em 2008 e o impacto em 2009 na movimentação de cargas e receitas dos armazéns dos terminais de carga aeroportuários. Durante o ano de 2007 a INFRAERO registrou em seus Terminais um crescimento na movimentação de carga exportada e importada, via aérea, em relação ao mesmo período do ano anterior. $\mathrm{Na}$ movimentação de carga exportada, a Empresa registrou crescimento de 9,5\%, passando de 259.177 toneladas (ton) em 2006 para 283.762 ton naquele ano. Com relação à carga importada, o crescimento registrado foi de $23,9 \%$, passando de 327.009 ton para 405.268 ton em 2007. Na soma das importações e exportações, o crescimento foi de $17,5 \%$, passando de 586.186 ton para 689.030 ton. A carga doméstica ou nacional também registrou crescimento, atingindo a importância de 210.698 ton em 2007, um aumento de 8,16\% em relação ao período anterior.

Em 2008 a movimentação de carga internacional foi de 724.222 ton, crescimento de $5,11 \%$ em relação ao período anterior e 217.753 ton. A carga doméstica obteve um crescimento de $3,35 \%$.

Em 2009 o setor sofreu com a crise econômica desencadeada nos Estados Unidos, afetando a demanda de importação e exportações nos terminais de carga brasileiros, fechando o ano com uma movimentação de 593.132 ton, uma redução de $19,48 \%$, sendo $-20,60 \%$ na importação e $-17,68 \%$ na exportação. A arrecadação neste segmento retraiu $18,62 \%$ fechando o ano com $R \$ 495,504$ milhões. No que diz respeito a carga doméstica houve um crescimento de 10,58\% em tonelagem, fechando o ano com 240.786 ton e uma arrecadação na ordem de $R \$ 14.276 .898$, 
um crescimento de $15,54 \%$ em relação a 2008 . Percebemos o equilíbrio do mercado interno brasileiro frente à crise pela manutenção do crescimento do consumo, se tornando a cada ano uma atividade promissora e com grandes oportunidades de negócio.

A logística de carga aérea no Brasil é uma atividade cada vez mais significativa na economia nacional, apresentando importante crescimento ao longo da década. Alguns aeroportos se destacam neste setor, como o Aeroporto Internacional de Brasília Presidente Juscelino Kubitschek (AIB-PJK), considerado um hub ${ }^{1}$ no transporte aéreo de passageiros e líder no transporte de cargas no Centro-Oeste Brasileiro. Alvo de significativos investimentos para o próximo quadriênio em virtude dos mega-eventos que ocorrerão no Brasil e do esgotamento de sua capacidade no atendimento ao fluxo cada vez mais crescente de pessoas e cargas, destaca-se no mercado nacional por sua localização estratégica no centro político e geográfico brasileiro.

\subsection{Formulação do problema}

A falta de espaço para armazenagem de cargas que necessitam resfriamento em câmaras frigoríficas é um dos gargalos encontrados nos TECAs Brasileiros, apresentando também saturação nos principais Terminais de Carga Internacionais e Domésticos, perdendo receitas consideráveis para os Portos Secos, Correios e Companhias Aéreas. Em contrapartida, alguns terminais apresentam ociosidade, tornando-se improdutivos devido ao alto custo para manter a atividade.

Outro fator é ocupação por cargas em processo de perdimento (abandonadas pelo importador). Estas cargas causam prejuízo à empresa, pois não são recebidos os pagamentos pela armazenagem, o que em muitos aeroportos representam até $35 \%$ da ocupação dos armazéns, que operam no limite de capacidade. (ANAC, 2009).

Para os gestores dos Terminais de Carga Aérea da rede INFRAERO - e

\footnotetext{
${ }^{1}$ Hub: é um aeroporto que se destaca no contexto de um país ou região como foco de grande número de vôos.
} 
demais elos da cadeia logística, a visão global do processo que envolve o comércio aéreo de cargas é fundamental para as decisões estratégicas e investimentos no setor, que não possui uma produção acadêmica/científica tão rica quanto a dos outros modais de transporte. São uma série de leis, códigos, regulamentos, convenções e políticas públicas a serem obedecidas. Fluxos de informações e documentos que precisão de interligação e uniformidade entre os órgãos envolvidos; que precisam ser geridos eficazmente para garantir a celeridade dos processos, bem como relatórios e indicadores gerenciais mais precisos.

O sistema logístico pelo modal aéreo tem uma série de vantagens em relação aos outros modais. Apesar do seu alto custo de utilização, integrá-lo aos demais meios de transporte, para obter a combinação ótima de entrega do bem ou suprimento na ponta da cadeia, é fundamental para as organizações e satisfação dos clientes. Portanto, a identificação das características do comércio exterior brasileiro e o processo de deslocamento dos produtos pelo modal aéreo, são imprescindíveis na determinação dos investimentos no setor e nas estratégias para tornar o mercado cada vez mais atraente e promissor.

Logo, a construção de um novo Terminal de Carga no Aeroporto de Brasília é justificável, considerando os aspectos financeiros e operacionais, de evolução e geração de receitas, de volume de cargas movimentadas, das perspectivas e potencial no mercado regional e adequação tecnológica? Quais serão os impactos causados pela implementação desses projetos?

\subsection{Objetivo Geral}

Identificação dos principais fatores que justificam a construção de um novo Terminal de Carga do Aeroporto de Brasília, pela análise das séries históricas de receitas, produtividade, volume de cargas movimentadas e aspectos operacionais. 


\subsection{Objetivos Específicos}

- Analisar a movimentação financeira e física das cargas importadas, exportadas e domésticas do Aeroporto Internacional de Brasília;

- Levantar quais os pontos relevantes para tornar os terminais da INFRAERO mais competitivos em relação aos seus concorrentes;

- Identificar os gargalos na infraestrutura do Terminal de logística de Carga de Brasília e os aspectos mais relevantes na construção de um novo TECA;

- Avaliar a relação entre o Terminal de Passageiros e Terminal de Carga;

- Identificar os principais aspectos de inovação no último quadriênio no AIBPJK.

\subsection{Justificativa}

Identificar os fatores que justificam a construção de um novo terminal de carga aérea no Distrito Federal é fundamental para subsidiar os investimentos no setor. Com a Copa do Mundo da FIFA a ser realizada no Brasil em 2014 e as Olimpíadas em 2016, o país ficará em evidência no mercado mundial e com boas perspectivas de crescimento do Produto Interno Bruto (PIB). Devido ao crescimento do comércio exterior pelo modal aéreo nos últimos anos, o Governo Federal planeja grandes investimentos para melhoria da capacidade dos terminais de passageiros e terminais de carga, de forma a evitar o apagão logístico aéreo. O Aeroporto Internacional de Brasília possui um grande potencial devido a sua localização estratégica no centro político do país, e com a expansão do seu terminal de carga, um dos projetos da INFRAERO, poderá elevar substancialmente as receitas da empresa em longo prazo e o aquecimento do comércio do Distrito Federal. No que tange ao comércio exterior, estimulará a importação de cargas de alto valor agregado, principalmente medicamentos e equipamentos eletrônicos, e exportação de mercadorias diversas.

Compreender o papel da logística de carga aérea internacional e doméstica é fundamental para as pessoas físicas e jurídicas, que estão inseridas no mercado de 
produtos de alto valor agregado, tecnologia de ponta e de produtos com alta perecividade. Existe um grande potencial no modal aéreo a ser explorado e uma necessidade de maior integração com os outros modais.

Este trabalho é relevante para o meio acadêmico na área de transportes, por discutir a logística e a administração aeroportuária; o papel dos gestores envolvidos na atividade e gerar relatórios referentes à carga aérea brasileira. Identificar os pontos a serem melhorados no transporte de carga aérea e as reais necessidades de investimentos em infraestrutura e logística do setor, subsidiará planejamentos estratégicos, bem como futuros trabalhos científicos em áreas específicas e afins.

\subsection{Métodos e Técnicas de Pesquisa}

Foram utilizados os métodos de pesquisa exploratória quantitativa para obtenção de dados secundários e pesquisa descritiva qualitativa pelo método de entrevista dirigida, para obtenção de dados primários junto aos gestores públicos envolvidos na atividade de logística do AIB-PJK, ocupantes dos seguintes cargos: Superintende do SBBR, Gerente de Logística, Coordenador de Importação e Exportação, Coordenador de Carga Nacional, Coordenador de Facilitação e Atendimento ao Cliente, Encarregados de Atividade de TECA e Coordenador de Logística de Carga da Superintendência Regional do Centro-Oeste (SRCO). Os dados secundários foram coletados junto a órgãos e organismos nacionais e internacionais relacionados ao comércio exterior, entre eles ANAC, $\mathrm{ACl}, \mathrm{ICAO}$, BNDES, INFRAERO, TIACA. Foram consultadas bibliografias diversas nas áreas de administração da produção, aviação civil, transporte de carga aérea e logística, anuários estatísticos, trabalhos acadêmicos e artigos e periódicos disponibilizados na internet.

Foram coletadas informações em relatórios contábeis e estatísticos da INFRAERO e no sistema de gerenciamento de carga da INFRAERO - TECAPLUS. 


\section{REFERENCIAL TEÓRICO}

Os tópicos apresentarão ao leitor os elementos básicos que envolvem a administração da cadeia de suprimentos e o comércio de mercadorias pelos diversos modais de transporte existentes. Administração da Produção, Logística, Transporte de Carga e Comércio Exterior serão abordados sucintamente, de forma a subsidiar a compreensão dos capítulos apresentados posteriormente com maior especifidade.

\subsection{Gestão da Produção/Operações}

O desenvolvimento da raça humana está intimamente ligado ao ato de produzir utensílios e bens conforme suas necessidades. Na Idade da Pedra o homem começou a desenvolver técnicas e ferramentas que permitissem a caça e coleta de alimentos. Posteriormente, com a junção de famílias formando tribos, e a junção destas formando cidades, o desenvolvimento agrícola foi se intensificando e a tecnologia se aprimorando; mas a produção ainda era artesanal e arcaica acompanhando a mentalidade da época; fundamentalmente teocêntrica e feudal.

Com o despontar do renascentismo, iluminismo e da globalização mundial, o processo produtivo se intensificou na Europa por meio do surgimento das organizações comerciais, que atingiram seu ápice a partir da Revolução Industrial em meados do século XVIII - fruto do crescimento das inovações tecnológicas, do êxodo rural e da ascensão da classe burguesa. Esse fato ocasionou o desenvolvimento econômico e social europeu e americano. Surgiram as organizações burocratizadas e sistematizadas, que tiveram como influência os teóricos da Administração, Engenharia e Ciências Sociais, tais como Taylor, Fayol, Ford, Mayo, Maslow, Weber e demais contemporâneos do século XIX, que direcionaram o processo produtivo, as relações sociais e econômicas, até o advento 
da Cultura Japonesa. Tais influências alavancaram os setores secundário (indústrias, manufaturas e prestadoras de serviços) e primário (extrativismo, agropecuária).

Um dos teóricos da administração define organização:

Todas as organizações são constituídas por pessoas e por recursos nãohumanos (como recursos físicos e materiais, financeiros, tecnológicos, mercadológicos etc.). Existem organizações lucrativas (chamadas empresas) ou não-lucrativas (como Exército, Igreja, serviços públicos, entidades filantrópicas etc.). A administração nada mais é do que a condução racional das atividades de uma organização seja ela lucrativa ou não-lucrativa. (CHIAVENATO, 2003. p. 2)

No Brasil, a industrialização se deu de forma tardia. Somente a partir de 1930, com o governo Vargas, houve investimento significativo na criação de infraestrutura industrial (indústria de base e energia). Destacando-se a criação do Conselho Nacional do Petróleo (1938), Companhia Siderúrgica Nacional (1941), Companhia Vale do Rio Doce (1943), Companhia Hidrelétrica do São Francisco (1945). (FGV/CPDOC, 2010).

Com a globalização comercial e as diferentes características dos países em relação a custos de mão-de-obra e matérias-primas, muitas empresas se transformam em transnacionais, ou seja, complementam o que produzem em determinado lugar, com partes produzidas por outras plataformas operantes em lugares muitas vezes distantes, provocando a descontinuidade geográfica da produção e a descentralização industrial - ainda fortemente caracterizada pelos moldes do colonialismo moderno, onde os colonos necessitam importar tecnologia e os detentores dos bens de capital insumos primários. A tecnologia da informação e comunicação e o transporte logístico integrado, são fundamentais para gerir a produção e entrega entre diferentes hemisférios do mundo. Utilizando-se de ferramentas administrativas modernas como o just-in-time, cross-docking e células de produção, a Administração da Cadeia de Suprimentos, ou Suply Chain Management do inglês, será bem articulada e com fluxos de informações integrados.

Para Martins e Laugeni (2005, p. 6), o objetivo da Administração da Produção/Operações é a gestão eficaz das atividades de transformação de insumos, tais como matérias-primas, em produtos acabados e/ou serviços, que consomem 
recursos e nem sempre agregam valor ao produtos final.

Segundo Kwasnicka (1995, p. 98), a produção é uma das atividades de uma organização que se resume basicamente na transformação de elementos de entrada, tais como materias-primas, tecnologia, capital, trabalho, demanda do mercado; em elementos de saída como bens, serviços e resíduos. A mesma autora classifica a função produção em três subsistemas: engenharia do produto, planejamento da produção e engenharia do processo.

O primeiro passo para o planejamento do produto é a pesquisa das necessidades dos consumidores. Podem ser criados novos produtos ou melhorados os já existentes, atribuindo a este um valor econômico de mercado e ser vendido na quantidade suficiente para cobrir os custos de produção. A elaboração do protótipo do produto é a fase inicial e envolve experimentos e testes, seguindo-se as especificações tais como: material a ser usado, padrões de desempenho, tolerância, dimensões, entre outros.

Após a fase inicial deve-se determinar a localização da planta, que levará em conta o mercado de mão-de-obra, acesso à matéria-prima, mercado consumidor, facilidades de infraestrutura (água, força, luz, clima etc.), incentivos fiscais e subsídios. Martins e Laugeni (2005, p. 30) dizem:

Os produtos podem ser fabricados em um determinado país ou importados de outro país, dependendo do que for mais competitivo para a empresa. Acontece também a regionalização de produtos, que não necessariamente é realizada no país consumidor, mas no centro de excelência mais adequado. A visão mercadológica da empresa não é mais o Brasil ou um conjunto de países, mas o mundo.

Definido o local da planta, o próximo passo é decidir a capacidade produtiva, conforme a capacidade do mercado consumidor e considerando a quantidade de horas de operação da fábrica, unidades em relação ao tempo, volume de vendas esperado, disponibilidade de matéria-prima, e capacidade instalada.

Stevenson (2001, apud GRAEML; PEINADO, 2007, p. 242) considera que a capacidade se refere a um limite superior ou teto de carga que uma unidade operacional pode suportar. A unidade operacional pode ser uma fábrica, um departamento, uma loja ou um funcionário. 
A capacidade efetiva representa a capacidade disponível subtraindo-se as perdas planejadas ou não desta capacidade. A capacidade efetiva não pode exceder a capacidade disponível, isto seria o mesmo que programar uma carga de máquina por um tempo superior ao disponível. Perdas de capacidade planejadas: são aquelas perdas que se sabe de antemão que irão acontecer, por exemplo: necessidade de set-ups para alterações no mix de produtos; manutenções preventivas periódicas; tempos perdidos em trocas de turnos; amostragens da qualidade etc. Perdas de capacidade não planejadas: são perdas que não se consegue antever, como por exemplo: falta de matéria-prima; falta de energia elétrica; falta de funcionários; paradas para manutenção corretiva; investigações de problemas da qualidade etc. (GRAEML; PEINADO, 2007, p. 245)

Finalmente chega-se ao planejamento, programação e controle da produção - PPCP, que segundo Martins e Laugeni (2005, p. 213): "É um sistema de transformação de informações dos estoques, vendas previstas, linha de produtos, know-how e capacidade produtiva". O PPCP deve informar corretamente a situação corrente dos recursos; o que envolve pessoas, equipamentos, instalações, materiais - ordens de compra e de produção, além de ser capaz de reagir de forma eficaz.

O grande dilema no planejamento da produção é definir o que produzir, quanto produzir, quando e com que recursos produzir, de forma a diminuir os problemas em relação à demanda flutuante, estoques e a logística de fornecimento e distribuição. Existem técnicas de programação de forma a distribuir as horas de trabalho em função do tempo e acompanhar a seqüência lógica de cada operação, mas quanto maior o mix de produtos, maior a dificuldade em prever a demanda de cada um dos produtos individuais a serem vendidos. O planejamento da produção inclui o planejamento da necessidade de materiais, a elaboração dos planos diários de produção baseados nos lotes mínimos de produção (em função do tempo e número de setups que precisam ser feitos), alocação de cargas nas linhas de montagem, entre outros inúmeros procedimentos.

A função produção está intimamente ligada às áreas de Marketing, Financeira e Logística, sendo necessária a utilização de tecnologias de informação integradas, de maneira a alcançar a eficácia e efetivo sucesso de qualquer organização empresarial. 


\subsection{Logística Empresarial}

Logística engloba basicamente a movimentação de matérias-primas, produtos acabados ou semi-acabados, desde a origem até o consumo final. As atividades primárias da logística são o transporte, manutenção de estoque, processamento de pedidos; as atividades secundárias são a armazenagem, capatazia (manuseio e embalagem), compras e informações sobre clientes, operações e fornecimento. A logística se desenvolveu juntamente com a administração de empresas, indo além da simples movimentação de mercadorias, se tornando uma atividade de planejamento e controle de fluxos de informações, de maneira a otimizar e minimizar os custos de estoque, distribuição, perdas e acima de tudo aumentar a satisfação do cliente pela entrega do produto no tempo adequado às suas necessidades.

Para a Society of Logistics Engineers (2010), logística se conceitua como:

A arte e a ciência das atividades técnicas, de gestão e engenharia
relacionadas com as necessidades e recursos de desenho,
aprovisionamento e manutenção (e manutenabilidade) necessários para
alcançar objetivos (resolver problemas), desenvolver planos e dar suporte a
operações. (GOMES; RIBEIRO, 2004, p. 2)

A origem da logística remonta ao início das civilizações e do aumento populacional, quando se fez necessária a produção abundante de alimentos e seu transporte aos centros urbanos ou campos de batalha. O termo surgiu inicialmente na área militar pelo deslocamento de suprimentos e de tropas, em grandes distâncias, e em um curto espaço de tempo. O termo tem raízes etimológicas no grego - logistiké; no baixo latim - logisticus e no francês logistique (MOURA, 2006).

Segundo Harrison e Hoek (2003, p. 27), a logística empresarial integra a gestão das áreas de finanças, marketing e produção, sendo um subconjunto de uma cadeia de suprimentos, ou seja, do deslocamento de insumos e a distribuição de bens aos clientes. Esta cadeia é responsável pelo fluxo de materiais (fornecimento e distribuição) e fluxo de informação de demanda dos clientes e produção.

Para Christopher (1998, apud HARRISON; HOEK, 2003, p. 28) a logística tem a seguinte definição: 
Gestão estratégica da obtenção, movimentação e armazenagem dos estoques de materiais, peças e produtos acabados e os respectivos fluxos de informações ao longo da organização e de seus canais de marketing, de tal modo que a lucratividade atual e futura sejam maximizadas por meio da realização de pedidos de compra de maneira eficaz em termos de custo.

A logística vai além do fornecimento e distribuição de mercadorias, abrangendo também o deslocamento de pessoas e a logística reversa. Muitas vezes há resíduos, produtos obsoletos, danificados ou inoperantes, que precisam ser descartados ou reaproveitados conforme a necessidade, retornando a cadeia logística ou sendo enviados para o tratamento sanitário mais conveniente. Diversos materiais descartados sofrem imposições da legislação ambiental ou das comunidades locais no que diz respeito ao descarte.

Temos dois ciclos neste segmento: o ciclo reverso de pós-consumo e o de pós venda. O primeiro relaciona-se aos bens industriais que depois de utilizados são descartados pela sociedade de diferentes maneiras e possuem ciclo de vida útil, ou seja, podem ser reciclados ou reutilizados após revalorização. O ciclo reverso de pós-venda relaciona-se aos bens industriais usados ou sem vida útil que são devolvidos para a cadeia de suprimentos por diversos motivos, tais como: por terminar a validade deles, por haver estoques excessivos no canal de distribuição, por estarem em consignação, por apresentarem problemas de qualidade e defeitos.

Segundo o Reverse Logistics Executive Council (2010), a logística reversa é:

O processo de planejamento, execução, controle da eficiência, da eficácia e do custo e fluxo de matérias-primas, estoque em processo, produtos acabados e informações relacionadas desde o ponto de consumo até o ponto de origem a fim de recapturar valor ou descarte apropriado.

Segundo Fleury (2003) Os custos logísticos podem representar até 30\% dos valores das vendas dos produtos e $12 \%$ do PIB mundial, sendo que o custo de transporte é o de maior relevância dentre os demais, absorvendo de um a dois terços do total dos custos. Devido à concorrência cada vez mais acirrada entre as empresas e o aumento do nível de exigência dos consumidores, as organizações se viram forçadas a investir em Sistemas de Informações Logísticas (SIL), de maneira a atender os clientes em tempo satisfatório às suas necessidades. Foram desenvolvidos Sistemas integrados de Planejamento dos Recursos Materiais, conhecidos como ERP - Enterprise Resource Planning do inglês, que consiste basicamente na integração das áreas funcionais da empresa (produção, marketing, 
vendas, compras, finanças, contabilidade, recursos humanos entre outras) com informações em tempo real, reduzindo, com isso, custos e o Lead Time (tempo de aprovisionamento), otimizando a tomada de decisão e a redundância de atividades.

\subsection{Transporte de Carga}

Transporte é o deslocamento de algo tangível de um lugar para outro, ou intangível como a informação. Pessoas e ou mercadorias utilizam diversos veículos ou modais para o transporte, tais como: rodovias, ferrovias, hidrovias, dutovias e aerovias.

Historicamente o transporte era feito por intermédio de animais, o que dificultava o desenvolvimento econômico e social dos países. Com a evolução tecnológica, as pessoas e os bens puderam se locomover a grandes distâncias e de forma intensa e volumosa. O transporte de carga abrange os cinco modais supracitados e três segmentos principais: infraestrutura, veículos e operações comerciais. A infraestrutura é que permite a operacionalidade dos modais como os terminais de embarque e desembarques, rodovias, ferrovias, canais fluviais, rodoviárias, portos, aeroportos, matriz energética, entre outros. Os veículos de transporte abrangem automóveis, embarcações, trens, dutos, aviões, etc. As operações estão relacionadas ao conjunto de procedimentos especificados em leis, códigos, regulamentos, convenções, políticas públicas e comerciais de gestão do sistema logístico.

Segundo Bowersox et al (2006, p. 274), existem dois princípios econômicos fundamentais que causam impacto na eficiência dos transportes: a economia de escala e a economia de distância. A economia de escala é o custo por unidade de peso diminuido à medida que aumenta o tamanho dos embarques. De uma maneira geral, veículos de maior capacidade, como no transporte ferroviário e marítimo, custam menos por unidade de peso do que os rodoviários e aéreos. A economia de distância se refere à diminuição do custo de transporte por unidade de peso conforme aumenta a distância; por conseguinte, distâncias maiores permitem que custos fixos sejam diluídos em uma maior quilometragem, resultando em menor custo por quilômetro. 
Alguns autores descrevem os tipos de modais (Ballou, 2006, KEEKI, 2005):

- Ferroviário:

É basicamente um transportador de longo curso e de baixa velocidade para matérias-primas (carvão, madeira, produtos químicos) e para produtos manufaturados de baixo custo (alimentos, papel e produtos florestais), sendo mais viável mover cargas completas.

- Rodoviário:

Em contraste com a ferrovia, o serviço rodoviário transporta geralmente produtos semiprontos ou acabados. As vantagens inerentes do transporte rodoviário são o serviço porta-a-porta, sem necessidade de transbordo na carga ou descarga entre origem e destino (esse inevitável nos modais ferroviários e aéreos); possuindo freqüência e disponibilidade do serviço, velocidade e comodidade inerentes ao serviço porta-a-porta. Diferentemente do transporte ferroviário que trabalha com cargas completas, ou seja, deve carregar todos os vagões para embarque, o rodoviário trabalha com cargas fracionadas - levando vantagem nos serviços com cargas de menor porte.

- Aéreo:

Com o uso cada vez mais crescente, embora possua taxas mais de duas vezes superiores ao do transporte rodoviário, seis vezes ao marítimo e dezesseis vezes mais caras que o transporte ferroviário. A capacidade do serviço aéreo tem sofrido enormes restrições em decorrência das dimensões físicas do espaço de cargas e limitações de potência de aeronaves, apesar que aeronaves de maior capacidade terem entrado em operação como dos fabricantes Boeing, Airbus, Antonov, e llyushin, que transportam entre 50 a 275 toneladas de carga, alguns de uso exclusivamente militar ${ }^{1}$. O serviço de transporte aéreo existe nas formas legais comuns, contratado e privado. Existem sete tipos de serviço aéreo: 1) transportadores de carga geral de linha (transporte de passageiros e carga); 2) transportadores de carga geral (cargo); 3) linhas aéreas regionais; 4) transportadores suplementares; 5) táxi aéreo; 6) linha aéreas comutadoras -

\footnotetext{
${ }^{1}$ Kaufmann, G. Oliveira. Transporte Aéreo de Carga: análise do setor e das tecnologias utilizadas. Monografia (bacharelado em Administração). Universidade de Brasília, 2009. p. 51-54.
} 
aqueles que operam em linhas abandonadas pelas grandes empresas; 7 ) Empresas Internacionais. Quanto ao tipo de aeronave temos três subdivisões: All Cargo destinada exclusivamente ao transporte de carga; Combi - transporta passageiros e carga nos decks inferior e superior; Full Pax - avião de passageiros, que transporte cargas apenas no deck inferior. Abaixo alguns modelos de aeronave.

Tabela 1:Características de algumas aeronaves transportadoras de cargas.

\begin{tabular}{|c|c|c|c|c|c|}
\hline Aeronave & $\begin{array}{c}\text { Consumo de } \\
\text { Combustível }[\mathrm{kg} / \mathrm{h}\end{array}$ & $\begin{array}{l}\text { Peso Máximo de } \\
\text { Decolagem [kg] }\end{array}$ & $\begin{array}{c}\mathrm{N}^{\circ} \text { de } \\
\text { Assentos }\end{array}$ & $\begin{array}{l}\text { Peso Máximo de } \\
\text { Carga Paga [kg] }\end{array}$ & TIPO \\
\hline \multirow{2}{*}{ A300 } & \multirow{2}{*}{6.300} & \multirow{2}{*}{165.000} & 234 & 35.424 & PAX \\
\hline & & & - & 40.000 & CARGA \\
\hline \multirow{2}{*}{ DC10 } & \multirow{2}{*}{8.450} & \multirow{2}{*}{263.084} & 232 & 44.622 & PAX \\
\hline & & & & & CARGA \\
\hline \multirow{2}{*}{ MD11 } & \multirow{2}{*}{7.700} & \multirow{2}{*}{280.320} & 282 & 52.105 & PAX \\
\hline & & & - & 92.554 & CARGA \\
\hline \multirow{2}{*}{ B747-300 } & \multirow{2}{*}{11.800} & \multirow{2}{*}{377.842} & 399 & 65.371 & PAX \\
\hline & & & 265 & 80.279 & Combi \\
\hline
\end{tabular}

Fonte: Horonjeff (1993) apud Oliveira 2007.

Um dos pontos relevantes no transporte de carga é a necessidade de cubagem, ou seja, quando uma carga possui grande volume e pouco peso, a tarifa cobrada será determinada em função do volume efetivamente ocupado no compartimento da aeronave. Peso Real: É aquele indicado na balança. Peso Cubado: É a forma de cálculo definida pela IATA para cargas com característica volumétrica superior ao peso real. É um critério para verificação do espaço efetivamente ocupado por volumes de grandes dimensões. Esse modal apresenta custos fixos globais baixos, custos variáveis mais elevados, maior velocidade mas restrições à capacidade.

- Aquaviário:

É o realizado em vias aquáticas por meio de navios, barcos, barcaças e suas variações. O transporte aquaviário é o mais importante em todo o mundo no comércio internacional; absoluto na liderança, sendo ideal para mercadorias de baixo e médio valor agregado. É divido em marítimo, fluvial e lacustre. A navegação marítima no país é denominada cabotagem, ou seja, entre os portos nacionais. É muito grande a capacidade disponível, podendo transportar até 400 toneladas. Os custos em perdas e danos resultantes do transporte hidroviário são considerados baixos em relação aos de outros modais. 
- Dutoviário:

A diversidade de produtos transportados por dutos é limitada, restringindo-se basicamente ao petróleo e derivados, e ao gás natural. A movimentação da "carga" por dutos é lenta embora seja compensado pela operação 24 horas/dia. Em relação ao trânsito, a dutovia é o meio mais confiável de todos os modais, já que são quase nulas as interrupções causadoras de variabilidade do tempo e os danos ou perdas são reduzidos, principalmente porque os líquidos e gases não são sujeitos a danos em grau semelhante ao dos produtos manufaturados e o número de riscos que podem afetar uma operação dutoviária é limitado. Abaixo a comparação entre modais:

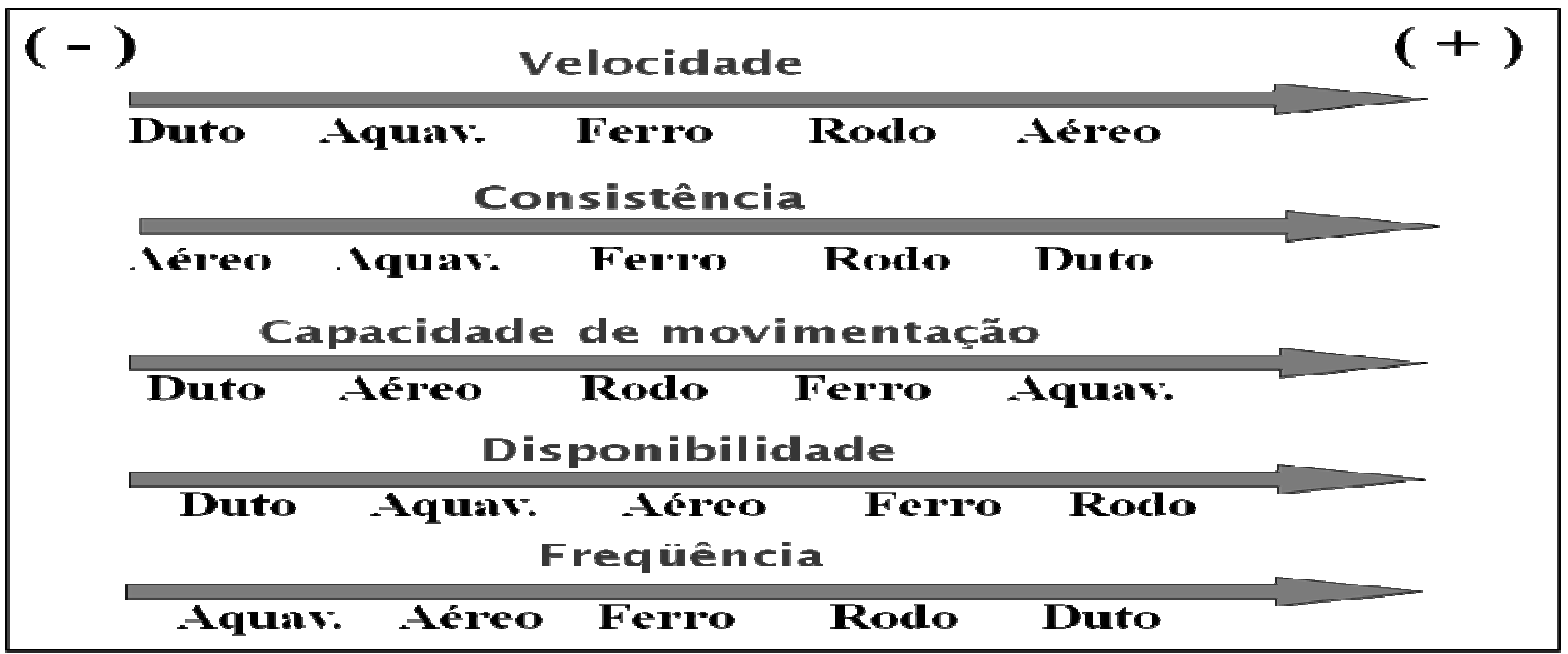

Figura 1: Comparação entre os diversos modais de transporte Fonte: Fleury et al (2003)

- Intermodalidade

A intermodalidade se diferencia da multimodalidade no que se refere ao transporte de carga, segundo alguns autores. O transporte intermodal é aquele que movimenta bens em uma única unidade de carregamento, sem manuseio dos bens na mudança de um modal para outro, utilizando diferentes conhecimentos de transporte ou emitindo novas notas fiscais para cada modal empregado. O transporte multimodal é aquele que utiliza vários modais utilizando um único contrato desde a origem até o destino, cujo operador de transporte é o responsável pelas perdas e danos às mercadorias. (JUNIOR, 2002)

Estes conceitos são divergentes no meio acadêmico e internacionalmente, sendo o termo intermodalidade tecnicamente correto. $O$ termo multimodalidade não apresenta a idéia de integração ou conexão entre os meios de transporte utilizados, 
mas expressa a idéia de que existem dois ou mais meios de transporte independentes e sem conexão ou integração logística.

Para Júnior (2002, p. 11) a multimodalidade se conceitua como:

É o transporte de mercadorias por dois modos de transporte, pelo menos, em virtude de um contrato de transporte multimodal, desde um lugar situado em um Estado-Parte em que um operador de transporte multimodal toma as mercadorias sob sua custódia, até outro lugar designado para sua entrega, situado em um Estado-Parte diferente, compreendendo, além do transporte em si, os serviços de coleta, unitização ou desunitização da carga por destino, armazenagem, manipulação e entrega da carga ao destinatário, abarcando os serviços que foram contratados entre a origem e o destino, incluídos os de consolidação e desconsolidação das cargas.

Por outro lado, a intermodalidade foi conceituada no Internacional Transport Forum (1993): "O movimento de bens em uma única unidade de carregamento, que usa sucessivos modais de transporte sem manuseio dos bens na mudança de um para outro". Segundo Fleury et al (2003) a intermodalidade corresponde a fase de integração total da cadeia de transporte, de modo a permitir um gerenciamento integrado de todos os modais utilizados, bem como das operações de transferência, caracterizando uma movimentação porta a porta com a aplicação de um único documento.

O sistema intermodal necessita apresentar vantagens suficientes para compensar a interrupção do fluxo nos pontos de transição, ou seja, o tempo e custo nos pontos de transição devem ser mínimos, do contrário o transporte unimodal pode apresentar maior eficiência, principalmente para pequenas distâncias. A intermodalidade pode trazer alguns inconvenientes em termos de documentação das cargas, dificuldades no sincronismo entre as etapas do transporte, e ainda as complicações que o cliente pode ter com excessivos agentes para completar todo o percurso da carga.

De acordo com Fleury (2003), o Brasil possui hoje uma oferta de infraestrutura de transporte insuficiente para suas necessidades, ou seja, os quilômetros de vias por quilômetros quadrados de área territorial são bem inferiores a de outros países de dimensões territoriais similares; o índice brasileiro de $26,4 \%$ é bastante inferior ao da China com 38,3\%, ao do México com 57,2\%, e ao dos EUA 
com 44,7\%. De todos os problemas que afetam o transporte de cargas no Brasil, o mais preocupante é certamente a distorção da matriz de transportes brasileira. Enquanto países de grandes dimensões territoriais, como EUA, Canadá, China e Rússia utilizam predominantemente os modais, ferroviário e aquaviário, em detrimento do rodoviário, no Brasil o que se observa é exatamente o contrário, ou seja, o predomínio absoluto do rodoviário. De acordo com Fleury (2003), no Brasil mais de $60 \%$ da carga é transportada por rodovias, contra $26 \%$ nos EUA, $24 \%$ na Austrália e $8 \%$ na China. Abaixo ilustra-se esse comportamento.

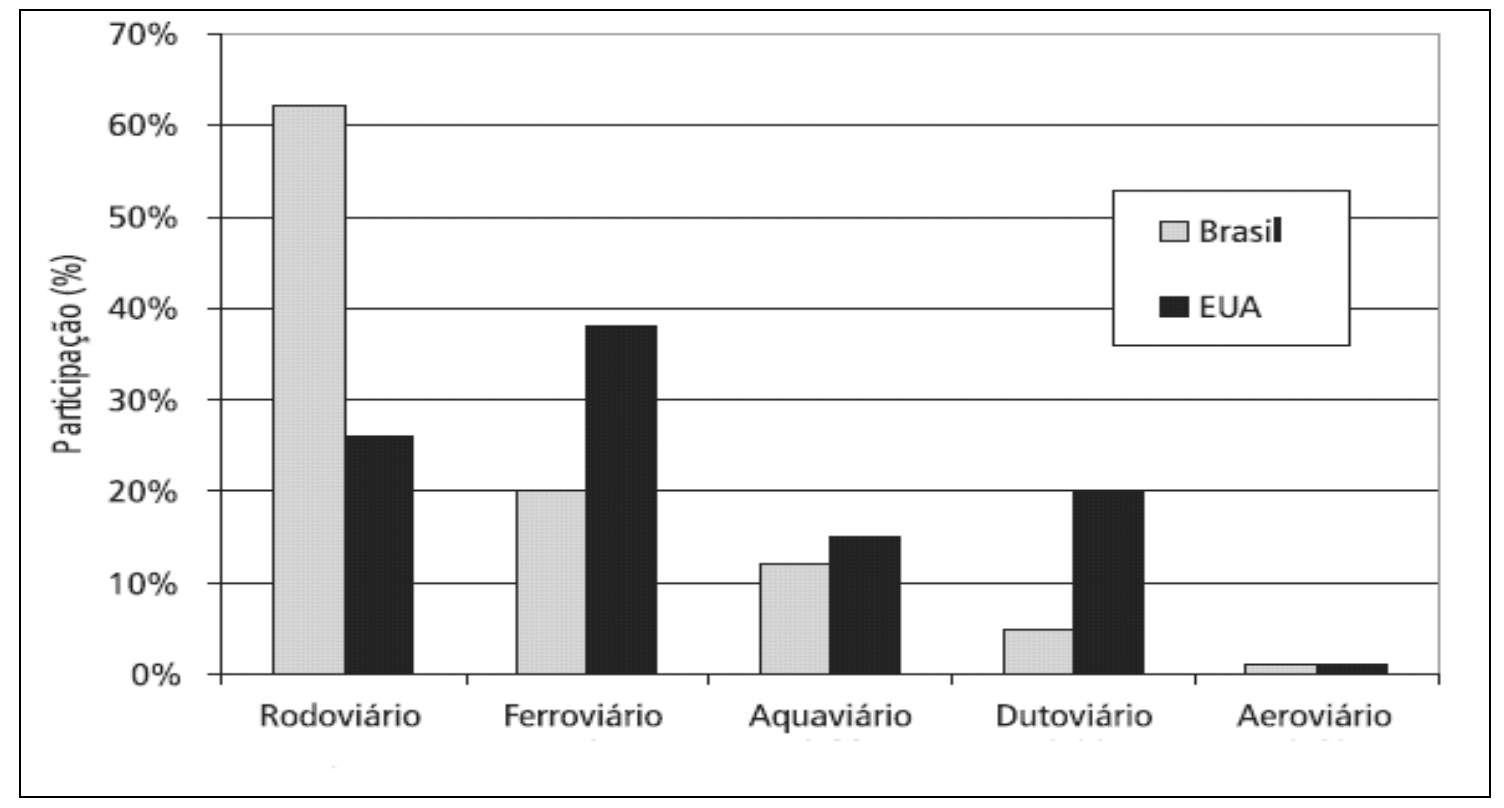

FIGURA 2: Comparativo entre as infraestrutura de transporte: BrasilxEUA Fonte: Fleury 2003.

A principal conseqüência da distorção da matriz de transportes é o impacto nos preços relativos cobrados por tonelada-quilômetro (ton/km) nos diferentes modais.

\subsection{Transporte de Carga Aérea Internacional}

O transporte de carga por aviões no mundo vem crescendo substancialmente devido aos avanços tecnológicos das últimas décadas. Segundo a Boeing, o mercado vem crescendo nos últimos anos a uma taxa de 1,5\% acima do crescimento do PIB. Para as próximas duas décadas estima-se um crescimento do 
mercado de carga áerea na ordem de 6,1\%. A frota cargueira aumentou sua capacidade de transporte e consequentemente reduziu o custo pela economia de escala, ou seja, o custo por unidade de peso diminui à medida que aumenta o tamanho dos embarques.

De acordo com a Airport Council International (ACI) em 2009 o número de passageiros nos aeroportos em todo o mundo caiu 1,8\% atingindo 4,796 bilhões, de um total de 4,882 bilhões em 2008. Oriente Médio (+7,7\%), Ásia-Pacífico (+4,9\%) e América Latina-Caribe $(+1,5 \%)$ mantiveram o crescimento. Europa e América do Norte registraram reduções significativas de $5,4 \%$ e 5,2\%, respectivamente, seguidos pela África $(-0,6 \%)$. O tráfego doméstico manteve-se estável, enquanto o tráfego internacional caiu 3,9\%. O movimento de aeronaves em todo o mundo diminuiu $5,1 \%$ atingindo 74,1 milhões, apesar de $38 \%$ dos aeroportos em todo o mundo registrarem um crescimento de passageiros, com uma média de $10,2 \%$. 0 volume de carga total movimentado nos aeroportos caiu 7,9\% atingindo 79,8 milhões de toneladas. Números que refletem o impacto da crise norte-americana, sendo importante ressaltar que uma queda no transporte de passageiros impacta o volume de cargas transportadas, cuja boa parte é feita na modalidade Combi.

A utilização do modal aéreo agiliza o transporte das mercadorias do ponto de produção ou montagem ao consumo final. Esse tipo de transporte ficou concentrado por muito tempo na utilização conjunta com o transporte de passageiros, não recebendo a devida importância pelos transportadores devido ao maior faturamento no transporte de pessoas. Apesar de transportar um volume menor de carga quando comparado com o modal marítimo, as receitas são elevadas devido as características das cargas transportadas, que possuem alto valor agregado e tecnologia de ponta. Geralmente são mercadorias que dependem de rápida movimentação e distribuição. Seu rival - o modal marítimo, transporta geralmente commodities (petróleo, grãos, minérios etc) e produtos industrializados por meio de contêiners, atendendo também cargas oversize e outsize, ou seja, aquelas que excedem tamanho de pallets, contêineres e o limite de peso dos equipamentos de carregamento, cujo transporte aéreo apresenta limitações na infraestrutura aeroportuária e na capacidade das aeronaves.

A carga aérea oferece aos clientes os benefícios do tratamento seguro, velocidade na entrega e facilidade em vencer obstáculos geográficos, mas com 
custos por quilograma em média seis vezes superior ao do modal marítimo, duas vezes ao rodoviário, dezesseis ao ferroviário, embora esses custos sejam compensados pela redução do tempo de armazenagem, entrega e inventário.

O transporte aéreo internacional segue os padrões determinados pela International Civil Aviation Organization (ICAO), ou Organização da Aviação Civil Internacional ( $\mathrm{OACl})$, que é uma agência especializada das Nações Unidas criada a partir da Covenção de Chigaco em 1944, tendo como objetivos o desenvolvimento de princípios e técnicas de navegação aérea internacional e a organização e o progresso dos transportes aéreos, de modo a favorecer a segurança, a eficiência, a economia e o desenvolvimento dos serviços aéreos. Podemos também destacar o papel da International Air Transport Association (IATA,) ou Associação do Transporte Aéreo Internacional; uma entidade do comércio internacional, criado há 60 anos por um grupo de companhias aéreas. Hoje, a IATA representa cerca de 230 companhias aéreas, compreendendo $93 \%$ do tráfego aéreo internacional regular. $A$ organização também representa, lidera e serve a indústria da aviação em geral. Atua na segurança operacional da aviação civil e gestão de risco, padronização de termos aeronáuticos, estabelecendo as melhores práticas para as operações em pátios e pistas, consultoria ambiental para o uso de combustíveis de forma racional, com diminuição da emissão de gases, consultoria na área financeira, entre outros.

As vantagens do transporte aéreos são, segundo Vieira (2003, p. 115): "Maior rapidez, o que facilita a utilização de estratégia just-in-time, com a consequente redução dos custos de estoque e sua influência no capital de Giro". O transporte aéreo de carga é fundamental para a circulaçao de mercadorias e abastecimento das cadeias de distribuição. Desde o início especializou-se em cargas de alto valor, mercadorias perecíveis, entregas de emergência para faltas imprevistas e produtos que exigem a garantia de maior cuidado. A relação entre o peso e valor implicam um custo de transporte de carga relativamente leve e custos de estoques elevados; se as mercadorias são de longo trânsito, os produtos altamente perecíveis incorrem em uma diminuição significativa no valor no caso de atraso.

O tráfego aéreo mundial é concetrado na América do Norte, Europa e Leste Asiático, conforme podemos observar na figura 3. A metade dos dez mais movimentados aeroportos ou 25 maiores terminais de carga, são portas dos maiores centros de consumo estabelecidos do mundo: Japão, China, Europa Ocidental e 
Estados Unidos da América. Estes centros comercializam não apenas produtos especializados, mas servem também como funis de entrada para as exportações dos países menos desenvolvidos e são plataformas da produção global, principalmente na China e Sudeste Asiático, compondo mais de um terço dos mais movimentados aeroportos de carga. Há novas plataformas emergentes na Índia, Vietnã e em outros lugares, mas ainda não estão no mesmo nível que aqueles. Dois aeroportos emergiram como centros intermediários de comércio, são eles o Aeroporto de Dubai - ligando Ásia e Europa, e o Aeroporto de Anchorage no Alaska ligando: Ásia, América do Norte e Europa.

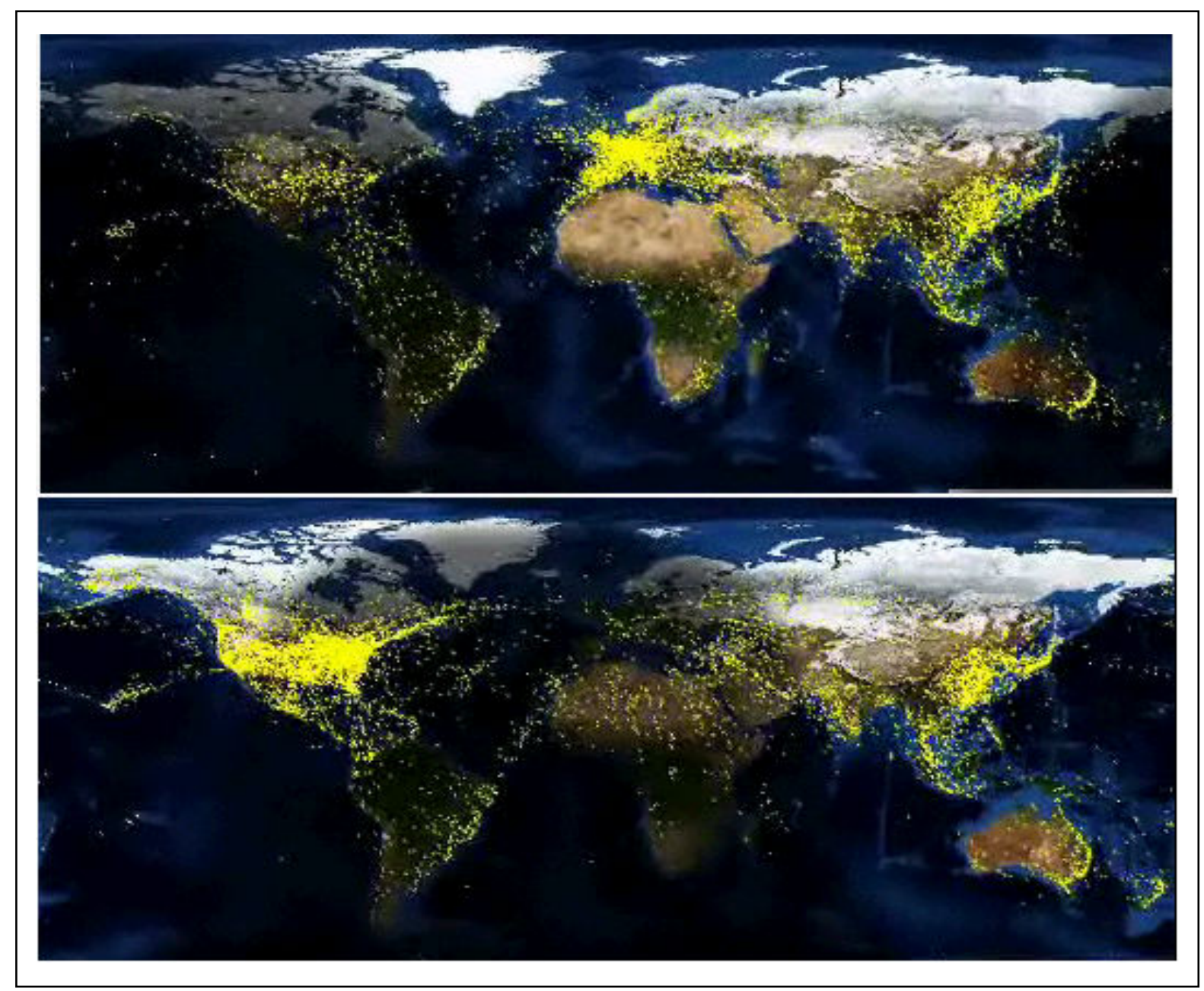

Figura 3: Tráfego aéreo mundial em 24 horas Fonte: www.gizmodo.com.br/

Os autores Wanke e Fleury (2003) descrevem o modal áreo, cujas principais características são: preço mais elevado de utilização, custos fixos globais baixos (aeronave e sistemas de manuseio) e custos variáveis mais elevados (combustível, mão-de-obra e manutenção); maior velocidade no trânsito; restrições à capacidade a 
ser transportada.

Segundo Kasarda (2006) a indústria aérea mundial movimentou quase 100 bilhões dólares em toneladas-milhas transportadas, uma estimativa de 52 bilhões de dólares em receitas diretas em 2005, sendo responsável por aproximadamente 29,9 (\%) do comércio internacional, e 34,6 \% das receitas não-terrestres de um montante anual de 2,7 trilhões de dólares em 2004. O serviço de transporte aéreo de carga possui, segundo estimativas, capacidade semanal de 4.396.353 toneladas disponíveis em mais de 3.400 aeroportos em 220 países.

Segundo a International Air Cargo Association (TIACA), a indústria de carga aérea tem prosperado na movimentação de produtos nos segmentos de microeletrônica, farmacêutica, componentes aeroespaciais, dispositivos médicos etc, representando aproximadamente três quartos da carga aérea internacional em termos de valor e $10 \%$ do comércio internacional enviado por via aérea, sendo que pelo menos um quarto do comércio deste segmento vai por via aérea. Além dos setores acima referidos são transportados diamantes, gravações de áudio e vídeo, produtos químicos e componentes de aeronaves, superando a cifra dos US $\$ 50$ bilhões em trocas comerciais.

A indústria eletrônica é fortemente dependente do ar, representando cerca de $40 \%$ do valor da carga aérea internacional, por si só (KASARDA, 2010). Esta indústria combina o alto valor-peso com produtos especializados, criando complexos canais internacionais de distribuição, de mão-de-obra especializada, onde quase toda a economia tornou-se dependente, ou seja, o conjunto da economia depende do frete aéreo e este depende muito da indústria de eletrônicos.

Nem todos os principais grupos de produtos no comércio mundial são - nem nunca serão - enviados por via aérea. Muito pouco de petróleo ou de produtos petrolíferos são enviados por via aérea. Poucos são os veículos a motor enviados por via aérea. Quase nenhum do comércio de ferro e aço é pelo ar e estes continuam a ser importantes componentes do comércio internacional. No entanto, a gama de produtos que podem ser efetivamente enviados por via aérea pode ser aprofundado através da melhoria da organização e eficiência do transporte aéreo. Uma das dificuldades encontradas no transporte aéreo de carga é que o fluxo é preponderantemente unidirecional, diferentemente do fluxo de passageiros que é bidirecional, ou seja, a demanda de passageiros é equilibrada na ida e na volta de 
determinado percusso, enquanto no caso do cargueiro o retorno é muito oneroso pela ociosidade do espaço, diminuindo significativamente a lucratividade.

Os serviços aéreos de carga estão espalhados por todo o mundo, cobrindo mais de 200 países e territórios independentes. A carga aérea está concentrada em algumas áreas mais que outras: os Estados Unidos sozinhos são responsáveis por um quinto das importações mundiais aéreas e mais um sétimo das exportações; seguidos pela Alemanha, Reino Unido, Japão, China (incluindo Hong Kong) e França, que correspondem pela metade das importações e exportações mundiais. Cingapura, Taiwan, Canadá, Coréia, Itália, México, Benelux (Bélgica, Países Baixos e Luxemburgo) e Brasil correspondem por três quartos das importações aéreas e 80 $\%$ das exportações mundiais. (KASARDA, 2006)

\subsection{Inovação}

Segundo Aurélio (2000) inovar é tornar novo; renovar, introduzir novidade. Este conceito se confunde com o de invenção, que é o descobrir algo ou criar uma maneira nova, original de se fazer alguma coisa. No entanto, inovar não é necessariamente criar, mas pode ser a otimização ou melhoria de um processo, de uma ferramenta, eliminação de desperdícios, etc. Dentro da perspectiva empresarial, a mudança de um produto ou serviço sem a contrapartida de aumento de rendimento não é inovação; inovar não é apenas quebrar a forma, mas alcançar retornos e ganhos de recursos ou capital. Uma inovação é implementada se for introduzida no mercado (inovações de produto) ou for usada dentro de um processo de produção (inovação de processo).

O ato de inovar é inerente a natureza humana e ao desenvolvimento da ciência e das técnicas de manipulação da natureza. A percepção do mundo e a reflexão levam o homem ao alcance do conhecimento por meio da razão e da experiência, levando-o a ciência, ao saber teórico e prático adquirido e aplicado a um fim determinado e ao aperfeiçoamento de técnicas para sobrevivência e aprimoramente da sociedade. A inovação está intimamente ligada a tecnologia, a busca de novos processos de fabricação, de comunicação, novos métodos e produtos, novos materiais, ou seja, ao crescimento dos conhecimentos científicos. 
O fato de se obter uma informação e esta não ter uma aplicação prática, não gera valor, não produz saber. Como afirma Reis (2004, p. 37): "a técnica e a tecnologia são domínios cognitivos mais próximos da ação, ambas têm relação com o saber fazer. Entretanto, pode-se definir a técnica como saber fazer tácito e a tecnologia como saber fazer explícito". As tecnologias não são isoladas, mas inseridas numa rede de apoio que inclui as relações físicas, informacionais e organizacionais que fazem uma tecnologia completa.

Segundo Matos e Guimarães (2006, p. 15) a tecnologia é formada pelos conhecimentos científicos, técnicos, empíricos e intuitivos empregados no desenvolvimento, produção, comercialização e utilização de bens e serviços, ou seja, o "know-how" - o saber fazer, o conhecimento e as ferramentas materiais necessárias. A tecnologia se desdobra em tecnologia do produto ou serviço, tecnologia de processos e tecnologia da informação e comunicação.

Segundo Reis (2004, apud Almeida, 1981) o conceito de inovação tecnológica formulado por Shumpeter contempla cinco casos a saber: Introdução de um novo bem, que os consumidores não conheçam, ou de uma qualidade nova do bem; ou um novo método de produção, ainda não testado no meio industrial, mas baseado em uma nova descoberta científica e que potencialmente seja um novo modelo de manuseio comercial; abertura de um novo mercado, cujo ramo da indústria na tenha penetrado, mesmo este já existente; conquista de uma nova fonte de fornecimento já existente, ou a ser criada;

As fontes de inovação podem ser externas (ou ambientais) ou fonte internas. As fontes externas são aquelas relacionadas à sociedade como um todo e que refletem, em grande medida, aspectos estruturais, resultantes de processos sociais de longo prazo. As internas, provenientes das organizações, são atitudes, recursos e mecanismos que, de um lado, levam a empresa a buscar deliberada e sistematicamente a criação e/ou introdução de inovações, influenciando o resultado desses esforços.

A gestão da tecnologia e da informação em uma organização deve identificar as demandas e ofertas tecnológicas internas e externas à organização e fomentar o desenvolvimento de ofertas para as demandas não atendidas, atentando para o ciclo de inovação que se constitui de pesquisa básica e aplicada, geração de idéia inovadora, desenvolvimento e aplicação no mercado. As inovações podem ser 
incrementais (pequenas melhorias), radicais (grandes melhorias) ou fundamentais quando o impacto da inovação for expressivo e possibilitar o desenvolvimento de muitas outras inovações.

O principal agente de mudança no mundo atual é a inovação tecnológica. $\mathrm{O}$ progresso econômico e social dos diversos países e o êxito das empresas, principalmente industriais, dependem da eficiência e da eficácia com que o conhecimento tecnocientífico é produzido, transferido, difundido e incorporado aos produtos e serviços (SBRAGIA et al, 1996; apud Reis, 2004).

Segundo Malerba (2004), o processo de inovação envolve diversos setores da economia, os quais alguns a mudança tecnológica acontece de forma rápida, como por exemplo no setor aeroportuário. Existem três variáveis principais que atuam nos processos de inovação a saber: conhecimentos e tecnologias; atores e redes ou agentes; e instituições. Conhecimento e tecnologias em setores em que a inovação é muito rápida, possuem limites setoriais móveis que mudam ao longo do tempo. Um setor é composto principalmente por agentes heterogêneos como as organizações e indivíduos (por exemplo, consumidores, empresários, cientistas). As organizações podem ser empresas (por exemplo, usuários, produtores e fornecedores de insumos) ou organizações não-empresariais (por exemplo, universidades, instituições financeiras, agências governamentais, sindicatos e associações técnicas). Neste contexto, o papel das instituições é fundamental, pois os agentes de aprendizagem, as ações e as interações são moldadas por elas, que estabelecem normas, rotinas, hábitos comuns, práticas, regras, leis, padrões e assim por diante. Elas podem ser nacionais ou segmentos de mercado específicos. As relações entre as instituições nacionais e os sistemas setoriais são muito importantes. Em primeiro lugar, as instituições nacionais - tais como o sistema de patentes, dos direitos de propriedade ou regulamentos anti-trust, têm efeitos diferentes sobre a inovação em diferentes setores. Em segundo lugar, a mesma instituição pode assumir características diferentes em países diferentes e, portanto, pode afetar a inovação diferentemente. Em terceiro lugar, as características das instituições nacionais, são muitas vezes a favor daqueles setores específicos aos quais se encaixam melhor. Em alguns casos, as instituições nacionais podem restringir o desenvolvimento de inovações em setores específicos, devido às defasagens ou interesses comerciais entre as instituições nacionais de um lado e 
instituições setoriais e agentes do outro lado. Em quarto lugar, a relação entre instituições nacionais e sistemas setoriais podem, às vezes, ir além do nível nacional.

A Primeira distinção de Schumpeter afirma que os setores são caracterizados por "destruição criativa", com a facilidade tecnológica de entrada e um papel importante desempenhado pelos empresários e novas empresas em atividades inovadoras. Segunda distinção diz que os setores são caracterizados por crescentes avanços tecnológicos, com a predominância das grandes empresas já estabelecidas e na presença de obstáculos à entrada de novos inovadores. Este regime é caracterizado pela predominância de um núcleo estável de algumas grandes empresas, com entrada limitada. A terceira distinção refere-se a setores que são fornecedores de rede de tecnologia e setores que são usuários da tecnologia. (MALERBA, 2004).

Nessa noção de sistema setorial de inovação e produção destacam-se cinco pontos-chave. Em primeiro lugar, foca-se no fornecimento, bem como sobre a demanda e mercados. Em segundo lugar, examinam-se outros tipos de agentes, além de empresas. Em terceiro lugar, coloca-se uma ênfase considerável nas interações do mercado e naquelas fora dele. Em quarto lugar, presta-se atenção às instituições. Em quinto lugar, foca-se sobre os processos de transformação do sistema e não considera os limites setoriais como pré-determinado e estático.

\subsection{Inovações Tecnológicas em Logística}

A evolução da logística está ligada a troca de informações entre fornecedores, clientes e operadores logísticos, permitindo a prática da reposição automática do produto na "prateleira" do cliente. O Sistema de Informação Logística (SIL), precisa ser abrangente e ter a capacidade de permitir comunicação entre as áreas funcionais internas e os demais membros do canal de suprimentos.

Para Ballou (2006, p. 133) no âmbito do SIL, os principais subsistemas são: sistema de gerenciamento de pedidos (SGP); sistema de gerenciamento de armazéns (SGA); sistema de gerenciamento de transportes (SGT). Cada um deles contém informações para objetivos transacionais, mas também ferramentas de 
suporte de decisões muito úteis no planejamento de atividades específicas.

Os sistemas de informação podem afetar toda a empresa e influenciar cada uma de suas atividades: logística, operações, comercialização, vendas e serviços; além do processo de tomada de decisão.

Segundo Gomes e Ribeiro (2004, p. 155):

Existem tecnologias e sistemas de Informações que permitem um
intercâmbio entre fornecedores e clientes, facilitando a transferência dos
dados de reposição dos estoques e da demanda do ponto-de-venda até o
fornecedor, não só de produtos, como também dos componentes e
materiais.

As aplicações hardware de Tecnologia de Informação-TI, para logística resumem-se em: microcomputadores, palmtops, códigos de barra, coletores de dados; radiofreqüência, transelevadores, sistemas GPS, computadores de bordo e picking automático (separação e preparação de pedidos). As aplicações softwares são: roteirizadores, WMS - Sistema de Gerenciamento de Armazém, GIS - Sistema de Informação Geográfica, DRP - planejamento das necessidades de distribuição, MRP - planejamento das necessidades de materiais, simuladores, otimizadores de rede, previsões de vendas e EDI - Intercâmbio Eletrônico de Dados (fornecedor / cliente). (GOMES; RIBEIRO, 2004).

Uma tecnologia cada vez mais utilizada é o RFID que utiliza espectros eletromagnéticos para transmitir informações sem contato e sem linha de visão, podendo ser definida como uma tecnologia de identificação que utiliza a rádiofreqüência para o intercâmbio de dados, permitindo realizar remotamente o armazenamento e recuperação de informações usando um dispositivo chamado de etiqueta de rádio identificação, um pequeno objeto que poderá ser afixado ou incorporado em um produto. Segundo Scavarda et al (2005), as principais vantagens da tecnologia RFID são: rapidez, precisão e confiança na transmissão de dados; elevado grau de controle e fiscalização - o que aumenta a segurança, evita furtos e falsificações; possibilidade de leitura de muitas etiquetas de forma simultânea; captação de ondas à distância, identificação sem contato nem visão direta do produto, possibilitando a codificação em ambientes hostis; simplificação dos processos do negócio - permitindo a redução da força de mão de obra, com 
transferência dos atuais empregados nestas atividades para outras atividades; rastreabilidade de produtos (controle de inventário) e de informação (ciclo de vida), que acarretam uma melhoria nas operações de gerenciamento e controle; alta capacidade de memória, que propicia o armazenamento de todas as informações pertinentes; leitura e escrita, que criam a possibilidade de constante atualização dos dados recebidos; durabilidade do estoque com possibilidade de reutilização.

O EDI (Electronic Data Interchange) é um formato-padrão para trocar dados de negócios; criado pelo American National Standard Institute ou Instituto Nacional Americano para Padronizações (ANSI), cujas mensagens contém uma sequência de elementos de dados, cada qual representando um fato singular, como um preço, um número de série ou quantidade; não precisando da ação humana para serem enviadas mensagens, mas sempre que ocorra determinado evento. O EDI é geralmente implementado por duas empresas mediante contrato e utiliza canais físicos contratados junto as operadoras de telecomunicações.

Os Sistemas de Informações Geográficas (GIS) são ferramentas que associam banco de dados a mapas digitalizados, auxiliando no processo de tomada de decisão. Um GIS completo consiste em pelo menos cinco componentes: software, hardware, dados geográficos, pessoal e organização. GIS possibilitam inúmeras aplicações. Com a aplicação de dados georeferenciados, podem-se executar diversas análises nas seguintes áreas: Geografia de Mercado ( localização de pontos comerciais); . localização de fábricas/roteamento e análises de sistemas logísticos já implementados.

Segundo Gomes e Ribeiro (2004), novas tecnologias vem sendo aplicadas nas empresas como o e-learning, t-commerce, c-commerce, m-commerce emarketplace:

a) E-learning: aplicações projectadas para funcionarem como salas de aula virtuais ou educação a distância, gerando várias possibilidades de interacção entre os seus participantes por meio da internet, que funciona como facilitadora, pois distribui a informação em larga escala e a baixo custo, como boletins, grupos de discussão e utilização maçiça de e-mails, permitindo também a comunicação simultânea entre alunos e professores.

b) T-commerce: é o comércio eletrônico (CE), via televisão, permitindo a 
navegação pela web por meio do uso do controle remoto da televisão.

c) C-commerce: negócios que utilizam a rede de colaboração que uma empresa é capaz de articular com parceiros, clientes, fornecedores e até mesmo concorrentes.

d) M-commerce: ou mobile commerce - Comércio por Dispositivos Portáteis sem Fio (wireless), como telefones celulares e PDAs (do inglês: personal digital assistants) - assistentes pessoais digitais. Permite que usuários acessem a internet sem necessitarem de um local fixo para conectaremse. Uma das tecnologias que mais prometem é a bluetooth, que possibilita que celulares tenham capacidades de fax, e-mails e transferências de arquivos.

e) E-marketplace: são portais e mercados digitais que aproximam compradores e vendedores em ambiente neutro. Pode ser por oferecimento pelo vendedor de catálogo on-line, leilões, cotações de vários venderores e leilão reverso, onde o comprador informa o produto que quer e o valor máximo que paga. Diversos fornecedores fazem o lance on-line e o vencedor é o que a faz a melhor oferta.

Desta forma, a logística empresarial deve estar preparada para atender a velocidade do comércio eletrônico com eficiência. A Inteligência de Negócios ou Business Intelligence - do inglês, é um processo de coleta, análise e distribuição de dados para melhorar a decisão dos negócios, levando as informações para um número bem maior de usuários dentro da organização. O sistema computacional identificará problemas específicos ou áreas problemáticas em um sistema, em particular gargalos, estoque intermediários acima do ideal e recursos eventualmente ociosos; auxiliando a estabelecer estratégias de investimento futuro para um sistema já existente, mostrando melhor quando e quanto se tem a ganhar a cada nova etapa.

\subsection{COMÉRCIO EXTERIOR}

Com o crescimento das populações dos diversos países do mundo, surgiu a necessidade de adquirir bens diversificados daqueles produzidos internamente ou 
escassos, bem como a oportunidade de expandir as fronteiras comerciais. As relações comerciais levou ao desenvolvimento da economia internacional e do ato de importar e exportar mercadorias.

Segundo KEEDI ( 2005, p. 17):

Exportar é o ato de remeter a outro país mercadorias produzidas em seu próprio ou em terceiros países, que sejam de interesse do país importador, e que proporcionem a ambos envolvidos vantagens na sua comercialização ou troca. É portanto, a saída de mercadorias para o exterior. Importar é o ato inverso, ou seja, adquirir em outro país., ou trocar com este, mercadoreias de seu interesse, que sejam úteis à sua população e seu desenvolvimento, isto é, a entrada de bens produzidos no exterior.

Para Maia (1999, p. 26) o conceito se amplia: “a Economia Internacional é mais abragente e engloba o comércio internacional (exportações e importações), prestação de serviços, transferências unilaterais (donativos, remessas de ou para imigrantes) e movimento de capitais".

O progresso dos meios de transporte foi fundamental para o desenvolvimento da economia internacional e circulação de mercadorias. Com o advento das caravelas e a globalização o comércio internacional ganhou impulso, intensificando-se ainda mais com o invento das locomotivas, automóveis e aviões, que proporcionaram transportar toneladas de carga em grandes distâncias num curto espaço de tempo. Mas o maior destaque podemos dar ao desenvolvimento da tecnologia da informação e comunicação que viabilizaram a rapidez nas negociações internacionais.

As diferenças climáticas e dos recursos do solo entre os países levaram a cultivos de alimentos diversificados e extração de minérios e matérias-primas fundamentais para aqueles países com escassez natural. $O$ grau de desenvolvimento tecnológico determina o desenvolvimento econômico de uma nação. Os países detentores de tecnologias iram exportar bens de capital para os países menos desenvolvidos e terão vantagens econômicas devido a valor agregado destes fatores. A capacitação da mão-de-obra é outro fator determinante para se importar determinado bem, ou seja, pode ocorrer que determinada produção não seja viabilizada por este fator. Outros fatores também podem influenciar, tais como motivos políticos, estabilidade econômica e social interna, acordos bilaterais, 
medidas protecionistas comerciais, preservação do meio ambiente, entre outros.

Segundo Samir (2005, p. 25),: "o montante movimentado atualmente pelo comércio mundial, ou seja, o valor do conjunto da exportação e da importação dos diversos países que participaram das transações internacionais, é de cerca de 13 trilhões de dólares norte-americanos (US\$). A relação do comércio mundial com o seu PIB, este cerca de US\$ 32 trilhões, é de aproximadamente 40\%, representando uma média de $20 \%$ na exportação e $20 \%$ na importação".

De acordo com o Ministério do Desenvolvimento e Comércio Exterior (MDIC), em 2009, o comércio exterior brasileiro registrou movimentação corrente de US\$ 281 bilhões, com redução de 24,3\% sobre 2008, quando atingiu US\$ 371 bilhões. Esta retração é conseqüência da crise financeira internacional, que levou a uma depreciação dos preços internacionais de commodities agrícolas e minerais e queda da demanda por bens. As exportações encerraram o período com valor de US\$ 153,0 bilhões e as importações de US\$ 127,6 bilhões. Em relação a 2008, as exportações apresentaram redução de $22,7 \%$ e as importações de $26,2 \%$. O saldo comercial atingiu US\$25,3 bilhões em janeiro-dezembro de 2009, significando aumento de $1,6 \%$ sobre o consignado em 2008 , de US $\$ 25,0$ bilhões, motivado por uma redução menor das exportações em relação às importações. Na comparação com 2008, os produtos básicos decresceram 15,2\%, e os semimanufaturados e os manufaturados diminuíram, respectivamente, $24,3 \%$ e 27,3\%. Mesmo diante da redução das exportações de bens industrializados, este grupo de produtos respondeu por mais da metade $(57,4 \%)$ do total exportado pelo Brasil em 2009.

Do lado da importação, as compras de matérias-primas e intermediários representaram 46,8\% da pauta total, e as de bens de capital 23,3\%, demonstrando que a pauta brasileira de importação é fortemente vinculada a bens direcionados à atividade produtiva. As importações de bens de consumo representaram 16,9\% e as de combustíveis e lubrificantes, 13,1\%. Comparado a 2008, a categoria de combustíveis e lubrificantes foi a que registrou maior redução, 46,8\%, em razão principalmente da queda das cotações internacionais de petróleo, seguida de matérias-primas e intermediários $(-28,1 \%)$, bens de capital $(-17,4 \%)$ e bens de consumo $(-4,5 \%)$. Por mercados de destino destacou-se a Ásia. As vendas aumentaram $5,3 \%$, colocando a região na primeira posição de mercado comprador de produtos brasileiros em 2009, superando a União Européia e a América Latina e 
Caribe. (MDIC, 2010)

O Brasil tem relações comerciais com diversos países, os quais se destacam:

Como principal comprador dos produtos brasileiros destaca-se os Estados Unidos da América e, em ordem alfabética: Alemanha, Argentina, BélgicaLuxemburgo, Canadá, Chile, China, Colômbia, Coréia-do-Sul, Emirados Árabes Unidos, Espanha, França, Índia, Itália, Japão, México, Países Baixos (Netherlands), Reino Unido, Rússia e Venezuela. Com principais vendedores destacam-se o Estados Unidos e, em ordem alfabética, Alemanha, Arábia Saudita, Argélia, Argentina, Bélgica-Luxemburgo, Bolívia, Cingapura, Chile, China, Coréia-do-Sul, Espanha, França, Hong Kong, Índia, Indonésia, Iraque, Israel, Itália, Japão, Malásia, México, Nigéria, Países Baixos (Netherlands), Paraguai, Reino Unido, Rússia, Suécia, Taiwan, Uruguai e Venezuela. (KEEDI, 2005. p. 30)

Percebemos um processo de globalização cada vez mais intenso, que se consolidou no Brasil com as freqüentes viagens diplomáticas do atual presidente Luis Inácio Lula da Silva e acordos comerciais firmados nos últimos anos. O país tem diversos acordos para redução de tarifas de importação, todos concentrados nas Américas do Sul, Central e Norte, e sendo todos com países integrantes da ALADI - Associação Latino-Americana de Integração.

\subsection{O Processo de Importação}

A importação consiste no deslocamento de um bem do exterior para o Território Nacional, seja em razão de transação comercial, ou pelo envio de bagagem desacompanhada, necessitando cumprir rigorosamente os critérios oficiais preconizados nas normas comerciais, cambiais e fiscais vigentes. Segundo a legislação brasileira a importação se concretiza a partir da entrada do produto importado no Território Nacional, configurando-se a incidência do Imposto de Importação, cujo contribuinte é o importador, também denominado como adquirente.

A relevância da importação é abordada por Souza (2003, p. 104): 
hoje amplamente conhecidas e aceitas. Significa dizer que a importação de máquinas e equipamentos, a aquisição de novas tecnologias, a adoção de novos métodos e técnicas de produção, a modernização dos parques industriais e a ampliação do leque de alternativas de compras de insumos reduzem o tempo e o custo de produção das empresas.

Segundo Keedi (2005) o território aduaneiro do Brasil compreende todo o território nacional e a ele estende-se a jurisdição dos serviços aduaneiros. Isto quer dizer que o controle das mercadoreias importadas, ou aquelas por exportar, estende-se a qualquer parte do país. O território aduaneiro divide-se em zona primária e zona secundária. A zona primária é aquela por onde entram no território nacional os produtos estrangeiros importados pelo país, e por onde saem os produtos nacionais exportados para outros países, compreendendo a área terrestre e aquática, contínua ou descontínua, onde estão localizados os portos alfandegados; os aeroportos alfandegados e as áreas terrestres e adjacentes de fronteiras alfandegadas. Os Portos Secos constituem a zona secundária.

Área alfandegada significa estar autorizada pelo órgão competente - no caso a Secretaria da Receita Federal (SRF) no Brasil, à guarda, sob seu controle, de mercadorias importadas ou prontas à exportação. A zona secundária é o restante do território aduaneiro, isto é, o território nacional, incluindo as águas territoriais e o espaço aéreo. Tanto a zona primária quanto a secundária podem prestar-se à nacionalização de mercadorias importadas, ou a desnacionalização de mercadorias a serem exportadas, ou seja, podem ser transferidas de uma zona para outra ou entre as zonas primárias ou entre as zonas secundárias. Este processo se faz mediante o Documento de Trânsito Aduaneiro (DTA), emitido pela SRF.

A atividade de importaçao pode ser de forma direta ou indireta, por conta ou ordem de terceiros ou por encomenda. Na forma direta, o importador não trata com intermediários e pode, conforme o poder de negociação de cada parte, obter melhores preços para as mercadorias, podendo ser feitas também por meio de representantes ou agentes do exportador, sem que isto descaracterize a operação e ela deixe de ser direta. Mesmo que estes providenciem os procedimentos operacionais, trâmites legais e tudo que for necessário, a operação de comércio exterior é de conta do próprio fabricante, que é o exportador. Na forma indireta a operação é realizada por terceiros, como empresas comerciais exportadoras, visto que estas compram a mercadoria do fabricante para revenda; podendo encarecer os 
preços em relação à compra direta. $\mathrm{Na}$ importação por ordem e conta de terceiros, regulada pelas Instruções Normativas, SRF 225/2002 e SRF n 247/02, ocorre quando um interessado/adquirente terceiriza o serviço de comércio exterior, ou seja, a aquisição da mercadoria estrangeira é efetuada por intermédio de uma empresa, a qual atua na condição de importadora e promove em seu nome o despacho aduaneiro de importação, cujo negócio jurídico ocorre por meio de celebração de contrato, previamente firmado, o qual deverá compor o processo aduaneiro. $\mathrm{Na}$ importação por encomenda, regulada pela lei $n^{\circ} 11.281 / 06$ ' estabelece que a importação seja promovida por pessoa jurídica que adquire mercadorias no exterior para revendê-las a encomendante predeterminado, firmado por contrato de compra e venda celebrado entre as partes, o qual comporá o processo de importação.

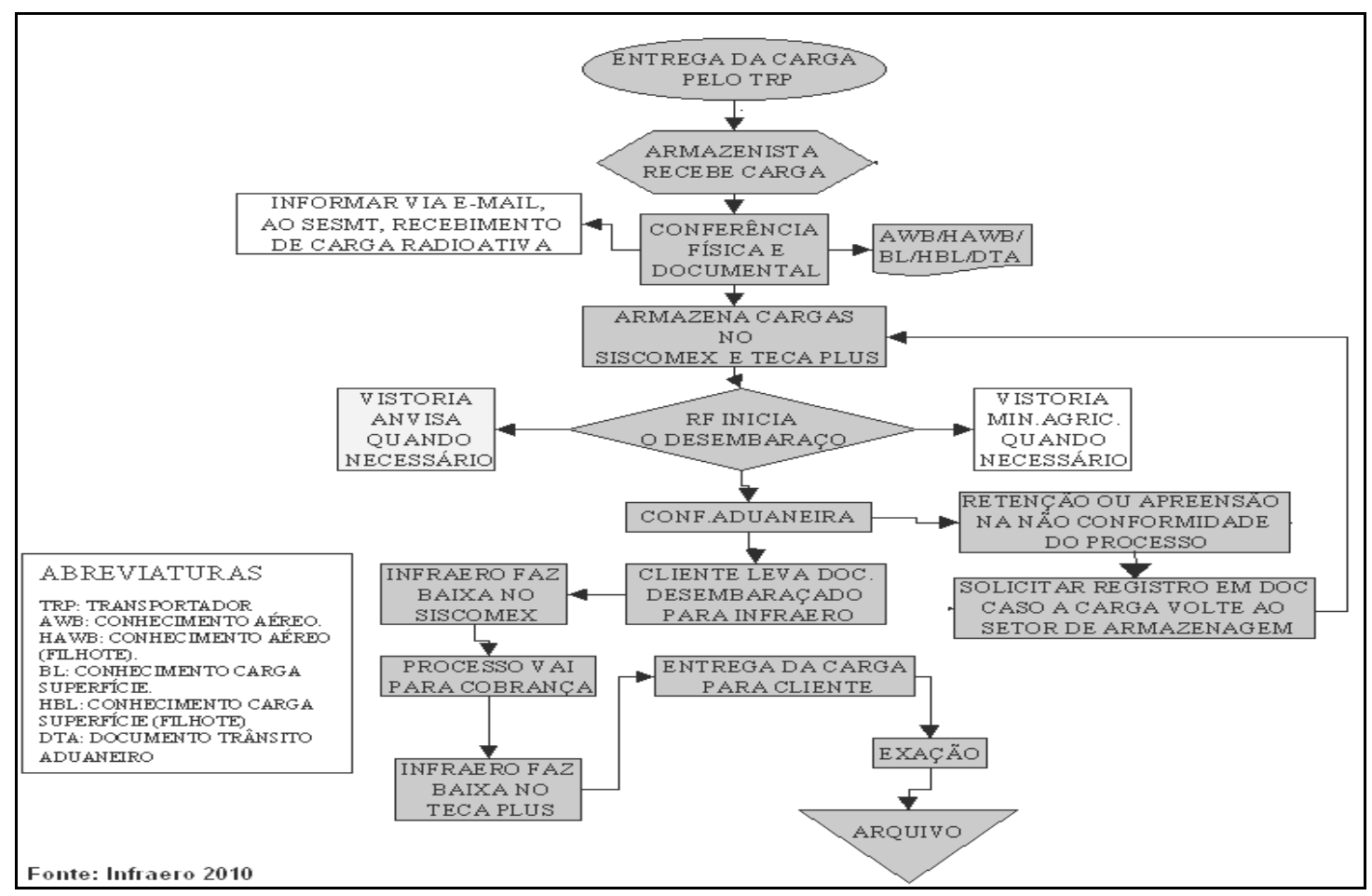

Figura 4: Fluxograma de Importação na rede INFRAERO ${ }^{1}$ Fonte: BRLC/SBBR; INFRAERO, 2010.

\footnotetext{
1 Conforme previsto no Art. 20 da IN - Instrução Normativa SRF - Secretaria da Receita Federal, n 206 de 25.09.2002. "Após o registro, a Declaração de Importação (DI), será submetida à análise fiscal e selecionada para um dos seguintes canais de conferência aduaneira": VERDE, AMARELO, VERMELHO ou CINZA. VERDE, pelo qual o sistema registrará o desembaraço automático da mercadoria, dispensados o exame documental e a verificação da mercadoria; AMARELO, pelo qual será realizado o exame documental, e, não sendo constatada irregularidade, efetuado o desembaraço aduaneiro; VERMELHO, pelo qual a mercadoria somente será desembaraçada após a realização do exame documental e da verificação da mercadoria; e CINZA, pelo qual será realizados o exame documental, a verificação da mercadoria e a aplicação de procedimento especial de controle aduaneiro, para verificar elementos indiciários de fraude, inclusive no que se refere ao preço declarado da mercadoria.
} 
As atividades desenvolvidas nos Recintos Alfandegados são limitadas a serem exercidas somente em espaços físicos delimitados nas áreas de portos e aeroportos. A importação é um processo administrativo, cambial, fiscal e comercial. Administrativo, uma vez que a operação, na maioria dos casos, deverá ter anuência prévia dos órgãos reguladores; cambial, quando na transação com moeda estrangeira sob o controle do Banco Central do Brasil (BACEN), por intermédio de bancos autorizados a operar o câmbio; fiscal, quando assegurado o recolhimento do tributo devido ou a aplicação de sanção com o propósito de evitar dano ao erário; e comercial, no que tange à relação do importador para com o Agente de Carga, a Seguradora, o Transportador e o Fiel Depositário. Abaixo, segue-se as definições dos elos supracitados, adaptado do Glossário de Comércio Exterior do Serpro:

a) Receita Federal do Brasil: O Órgão representante do Ministério da Fazenda, que exerce a atividade prevista no art. 237 da Carta Magna. Dentre as diversas competências atribuídas estão as de planejar, coordenar e executar o controle e a fiscalização aduaneira em todo território nacional, desenvolvendo a vigilância, a prevenção e a repressão aos crimes de contrabando e descaminho, com o propósito de evitar o dano ao erário

b) Importador: pode ser pessoa física ou jurídica previamente habilitada no sistema informatizado, administrado pelo Ministério do Desenvolvimento, Indústria e Comércio (MDIC), Secretaria de Comércio Exterior (SECEX), denominado Sistemas Integrados de Comércio Exterior (SISCOMEX), munido dos documentos exigidos, a fim de cumprir procedimentos previstos na legislação que regula o despacho aduaneiro de importação.

c) Agentes de carga: são empresas que oferecem serviços de transporte, documentação, coordenação e o embarque ou desembarque de cargas aéreas, marítimas, rodoviárias e ferroviárias internacionais. Possuem correspondentes no exterior e oferecem seus serviços aos proprietários de cargas. Segundo o Regulamento Aduaneiro: "o agente de carga, assim considerada qualquer pessoa que, em nome do importador ou do exportador, contrate o transporte de mercadoria, consolide ou desconsolide cargas e preste serviços conexos". (Lei no 10.833, de 2003, art. 77).

\footnotetext{
${ }^{1}$ http://www.glossarioce.serpro.gov.br/pagina.php
} 
d) Transportador de carga aérea: transportador, pessoa física ou jurídica, proprietário ou explorador da aeronave. Pelo novo Código Civil, Lei $\mathrm{n}^{\circ}$ 10.406/02, contrato de transporte é aquele onde alguém se obriga, mediante retribuição, a transportar, de um lugar para outro, pessoas ou coisas. As obrigações do transportador não surgem antes do recebimento das mercadorias, mas isso não impede a formação anterior do contrato, até porque ele contrai a obrigação de recebê-las.

e) Fiel Depositário: responsável pela atividade de recebimento, movimentação e armazenamento das cargas oriundas do exterior, no recinto alfandegado, mediado por Termo de Fiel Depósito emitido pela Receita Federal da jurisdição aduaneira. $O$ depósito nessa modalidade recebe a nomenclatura de Terminal de Logística de Carga Aérea Internacional - TECA. Desse modo, o fiel depositário é o Administrador Aeroportuário criado e definido por Lei. No caso dos aeroportos brasileiros o fiel depositário é a INFRAERO.

f) Seguradora: O seguro no comércio exterior é pré-requisito para a transação de compra e venda e para a operação relacionada ao transporte desses bens. Essa atividade é regulada e fiscalizada pelo Ministério da Fazenda, por intermédio da Superintendência de Seguros Privados - SUSEP/MF. O Código Brasileiro de Aeronáutica (Lei $n^{\circ}$ 7.565/86) delibera, a partir do art. 281 ao art.286, que todos os agentes que atuam no ramo aeronáutico devam ter o seguro para garantir indenização, nos casos de danos causados à carga, enquanto estiver sob sua guarda.

g) Despachante Aduaneiro no modal aéreo: O Exercício regular da função de Despachante Aduaneiro está previsto no Decreto $n^{\circ} 646 / 92$, que dispõe sobre a forma de investidura nas funções de despachante aduaneiro e de ajudante de despachante aduaneiro; no art. 810 e subseqüentes, do Regulamento Aduaneiro. Esse profissional poderá representar os importadores, exportadores, transportadores e armazéns perante as autoridades relacionadas com o processo aduaneiro, objetivando efetuar o desembaraço aduaneiro. Precede ao desembaraço o despacho aduaneiro, que é o procedimento mediante o qual é verificada a exatidão dos dados declarados pelo importador em relação às mercadorias importadas, aos documentos apresentados e à legislação específica, com vistas ao seu desembaraço 
aduaneiro. (Receita Federal, 2010).

A carga aérea nos aeroportos envolve um fluxo de informações expressivo, que é imprescindível para os trâmites legais do comércio exterior desde o embarque da mercadoria ao desembarque, identificação, circulação, liberação, despacho e recebimento. Dentre os documentos, segundo o Manual de Importação da Universidade Estadual Paulista (2003), podemos citar:

\section{Documentos emitidos pelo importador:}

a) Licença de Importação (LI): o documento eletrônico que deve ser preenchido "on line" pelo importador ou por seu despachante aduaneiro, por meio do sistema integrado de comércio exterior - SISCOMEX, sendo obrigatório nas importações com isenção de impostos.

b) Declaração de Importação (DI): é o documento base do despacho de importação, formalizado, pelo importador ou por seu despachante aduaneiro, no momento do desembaraço da mercadoria; sendo exigida em todas as importações e compreende o conjunto de informações comerciais, cambiais e fiscais necessárias à análise da operação e início do processo de desembaraço alfandegário.

c) Comprovante de Importação (CI) comprovante de importação é o documento que promove definitivamente a nacionalização da mercadoria. é um documento eletrônico, emitido pela secretaria da receita federal, e que comprova a efetiva nacionalização da mercadoria importada, por meio do pagamento de impostos, quando exigíveis.

\section{Documentos emitidos pelo exportador:}

a) Fatura: é o documento emitido pelo exportador, no qual se descreve todas as características das mercadorias, tais como: quantidade, preço unitário e total, peso líquido e bruto, nome e endereço do exportador, do fabricante, dados bancários, forma de pagamento, termos de garantia etc. Esta pode ser Proforma quando é emitida pelo exportador ou representante, precedendo a fatura comercial, a qual descreve a mercadoria e os termos de venda, servindo para fins de cotação e formalizando do que foi tratado pelas 
partes. Comercial/Invoice - é um documento internacional, emitido pelo exportador, imprescindível para que o importador possa liberar as mercadorias em seu país. A fatura comercial formaliza a transferência da propriedade da mercadoria, atesta o que está sendo embarcado e os termos negociados, bem como as características do produto vendido, podendo-se dizer que corresponde a uma "nota fiscal" internacional.

b) Packing List (ou romaneio): relaciona as mercadorias embarcadas dentro de suas respectivas embalagens (containers, pallets ou outros). contém também outras informações como, destinatário, quantidade de volumes, marcas etc.

c) Outros: dependendo do tipo de mercadoria ou importação, outros documentos poderão ser exigidos pelo importador, para apresentação na alfândega, tais como: certificado de origem, certificado fitossanitário, fatura consular etc.

\section{3. documentos emitidos pelo transportador:}

a) Conhecimento de Embarque Aéreo: do inglês Air Waybill - AWB, tem a finalidade de transferir a propriedade da carga, além de constituir prova de embarque; exercendo função de contrato de transporte e quando aplicável, de bilhete de seguro. Identifica os principais dados característicos da carga. Temos ainda o MAWB - Master Air Waybill, ou HAWB - House Air Waybill, quando se tratar de carga consolidada. A consolidação de cargas consiste no agrupamento, por um agente de cargas, de vários embarques, de um mesmo embarcador ou de diversos, para um mesmo destino final ou para redistribuição, com o intuito de beneficiar, pelo agrupamento, com o menor nível tarifário aplicável para o peso total do despacho, ou seja, como as tarifas aéreas existem em níveis cujos valores diminuem à medida que o peso aumenta, quanto maior o peso agrupado menor será a tarifa por quilograma a cobrar. 


\subsection{O Processo de Exportação}

A atividade de exportação empresarial é uma alternativa estratégica que as empresas encontram para expandir seus negócios, não sendo considerada meramente como uma saída temporária de crises no mercado doméstico ou venda de excedentes de produção, mas ganho em competitividade e aumento da produtividade e qualidade devido a competição acirrada no mercado internacional.

De acordo com Souza (2003, p. 20):

O desenvolvimento e o crescimento das exportações de uma empresa dependem da competência de seus empresários em desenvolver produtos que possam penetrar no mercado internacional, acompanhando o molde mundial; ou seja, observando as exigências em relação à segurança dos produtos, às normas técnicas e ao controle de qualidade.

Existem muitas razões para se exportar, as quais podemos citar: diversificação de mercado, expansão dos negócios, aprimoramento da qualidade, redução de custos pela utilização da capacidade ociosa, geração de novos empregos, incentivos financeiros e fiscais concedidos a empresas exportadoras. Para se iniciar na operação de exportação as empresas devem observar algumas etapas importantes: pesquisa de mercado e busca de clientes em potencial; remessa de amostras comerciais, recebimento de ordens de compra, enquadramento das operações às normas de comércio exterior do Brasil e das internacionais; coordenação entre produção e o tempor de transporte, confecção da documentação exigida pelas leis nacionais e pelas leis internacionais, tais como: invoice; packing list, certificado de origem e saque; desembarque aduaneiro, câmbio, entre outros.

O exportador pode ingressar no mercado externo de forma direta ou indireta. $\mathrm{Na}$ forma direta o exportador atua de forma independente e é responsável por toda a operação, promovendo seus produtos e negociando diretamente com os clientes. Os procedimentos podem ainda ser realizados por profissional especializado (trader), contratado exclusivamente para o desenvolvimento desta atividade. Na exportação direta, a empresa tem maiores chances de fortalecer seu nome e marca no mercado internacional. Na exportação indireta: o exportador realiza a operação através da 
atuação de um intermediário, que adquire a mercadoria no mercado interno com o fim específico de exportá-la. Os intermediários podem ser de três tipos: as trading companies, isto é, empresas comerciais com atuação internacional que usufruem de benefícios legais e tributários para a realização das operações, de acordo com o Decreto-Lei $n^{\circ} 1.248$, de 29 de novembro de 1972; as comerciais exportadoras, empresas semelhantes às trading companies porém sem regulamentação específica e a exportação compartilhada, que incluem a formação de consórcios e cooperativas para exportação, que reduzem o custo econômico da operação e aumentam sua eficiência, sendo ideais para as pequenas empresas exportadoras. Abaixo demonstra-se o fluxo da exportação na rede INFRAERO.

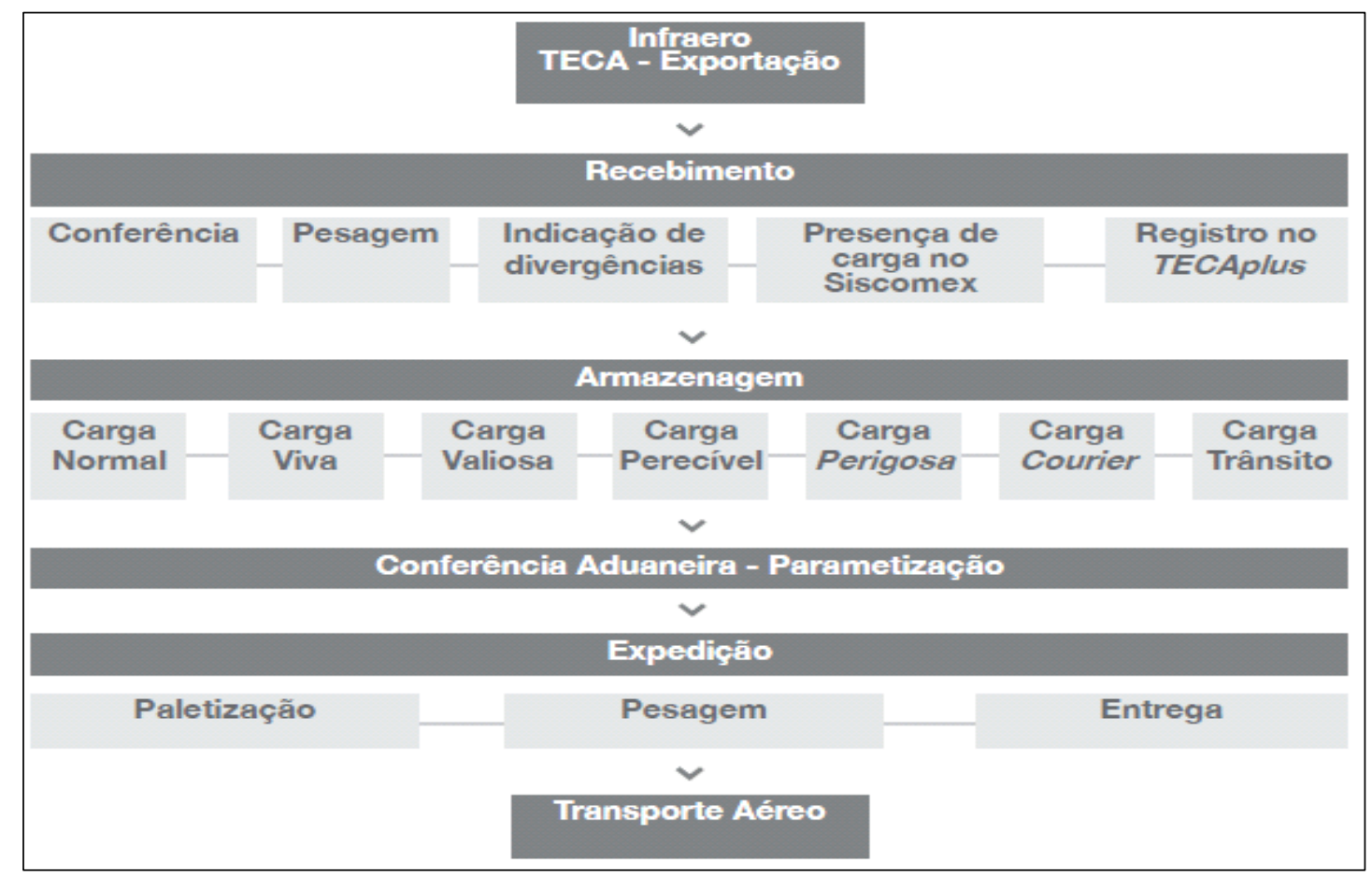

Figura 5: Fluxograma de Exportação na rede INFRAERO

Fonte: INFRAERO, 2010.

Os principais documentos são: Fatura Pró-Forma; Fatura Comercial, Packing List ou Romaneio de Embarque; Nota Fiscal; Certificado de Origem; Fatura Consular - alguns poucos países exigem a apresentação da fatura consular, documento similar à fatura comercial; Registros Eletrônicos no SISCOMEX (Registro de Exportação, Registro de Venda, Registro de Operação de Crédito, Registro de Exportação Simplificado, e Declaração Simplificada de Exportação); Saque ou Cambial (documento emitido pelo exportador contra o importador, em moeda estrangeira, que constitui o direito do exportador às divisas decorrentes da venda.) Conhecimento de Embarque; Certificado Fitossanitário: Apólice de Seguro; Contrato 
de Câmbio: contrato de compra e venda entre o exportador para transferir valor em moeda estrangeira proveniente de uma operação de exportação.Boleto de Compra e Venda Simplificado; Declaração de Despacho de Exportação (DDE). (MANUAL DE EXPORTAÇÃO. FIESP; SENAI, 2004).

\subsection{Administração dos Aeroportos Brasileiros}

Um aeródromo é toda área destinada a pouso, decolagem e movimentação de aeronaves, sendo classificados como civis (operação de aeronaves civis) e militares (operação de aeronaves militares). Os aeródromos civis podem ser subdivididos em públicos e privados. No Brasil, os públicos devem obedecer a um plano de zoneamento de ruídos e as propriedades vizinhas estão sujeitas ao um plano básico de zona de proteção de aeródromos. São abertos ao tráfego através de processo de homologação. Os privados só podem ser utilizados com a permissão de seu proprietário, sendo vedada sua exploração comercial - o proprietário não pode sujeitar os usuários de seu aeródromo ao pagamento de tarifas. Os aeródromos privados não têm zona de proteção garantida, podendo estar sujeitos a restrições operacionais motivadas por novas instalações ou construções no seu entorno. São abertos ao tráfego através de processo de registro e podem ser fechados a qualquer tempo pelo proprietário ou pela Autoridade de Aviação Civil. (ANAC, 2010).

Tabela 2: Infraestrutura Aeroportuária Brasileira

\begin{tabular}{|c|c|c|}
\hline \multirow{3}{*}{ Sistema Aeroportuário } & Privado & 1.759 \\
\hline & Público & 739 \\
\hline & Total de Aeródromos & 2.498 \\
\hline \multirow{6}{*}{$\begin{array}{c}\text { Aeródromos } \\
\text { por administração }\end{array}$} & INFRAERO & 67 \\
\hline & COMAER & 320 \\
\hline & Estados & 190 \\
\hline & Municípios & 155 \\
\hline & Aeroclubes & 9 \\
\hline & Empresas & 2 \\
\hline
\end{tabular}

Fonte: ANAC, 2009

Aeroportos são os aeródromos públicos ou privados dotados de instalações e facilidades para apoio de operações de aeronaves e de embarque e desembarque de pessoas e cargas. São fundamentais no desenvolvimento econômico e social do 
país, quer transportando pessoas ou cargas ou para a indústria aeronáutica e de infraestrutura. Engloba inúmeras cadeias produtivas que seriam inviabilizadas se não fosse a agilidade proporcionada no transporte aéreo. O crescimento cada vez maior da aviação civil-comercial levou a investimentos expressivos em infraestrutura como terminais de passageiros, hangares, pistas para pousos e decolagens com capacidade para grandes aeronaves, veículos auxiliares, terminais de cargas, câmaras frigoríficas, tecnologias da informação e comunicação; tudo isso para acompanhar a evolução da capacidade das aeronaves e aumento da demanda na utilização do modal aéreo.

Este aumento na utilização do modal aéreo atinge toda uma cadeia de serviços indiretos como restaurantes, estacionamentos, hotéis, agências locadoras de veículos e uma série de outros serviços ligados aos aeroportos, evidenciando a importância destes para a economia mundial. No Brasil são mais de 300 milhões de pessoas que transitam nos aeroportos todos os anos, segundo dados da INFRAERO. Para Vasconcelos (2007, p. 38) os aeroportos são locais onde são realizadas principalmente transferências modais e transbordos de passageiros, carga e correio. Portanto, esses equipamentos devem dispor de sistemas de recepção e de meios de acesso para essas transferências entre os modos de transporte aéreo e de superfície, devido ao modo aéreo não ser porta a porta.

De acordo com Silva (1990; apud Vasconcelos, 2007), assim como as estações ferroviárias e os portos, os aeroportos estão intimamente vinculados aos centros comerciais das cidades com as quais estão ligados, como um órgão indispensável à vida diária das metrópoles. Participam, inclusive, como atores econômicos, ao propiciar o aumento da renda dos lugares, seja por meio de sua atividade principal de estação com locais confortáveis para passageiros e manuseio e guarda de cargas, bem como para as demais atividades de suporte e secundárias.

Devido à complexidade e circulação de pessoas, os aeroportos são considerados como verdadeiras cidades, chamados por muitos autores como cidades-aeroporto. De acordo com Kasarda (2010), os aeroportos no mundo tornaram-se peças-chave na produção global e sistemas corporativos, ofertando serviço de transporte com velocidade, agilidade e conectividade. São elementos que alavancam o desenvolvimento econômico local, atraindo para seus arredores empresas ligadas à aviação de todos os tipos, turismo, lazer, etc. Estes incluem, 
entre outros, hotéis, entretenimento, varejo, convenções, complexos para exposições comerciais e científicas, edifícios de escritórios, office center para atender altos executivos e profissionais diversos, estruturas industriais. Esta evolução espacial e funcional está transformando a circunvizinhaça dos aeroportos das cidades em "municípios" do aeroporto. À medida que mais e mais empresas de aviação estão sendo atraídas para as cidades-aeroporto e ao longo dos corredores de transporte que irradiam a partir deles, uma nova forma urbana está surgindo: o Aerotropolis - que se estende até 20 milhas (30 km) para fora de alguns aeroportos. Mas os aeroportos também trazem alguns inconvenientes como ruídos -que atingem a vizinhança do aeroporto, degradação ambiental para a construção das megaestruturas aeroportuárias, produção de resíduos, etc.; sendo necessário implementar programas ambientais para atuação em variadas frentes, tais como licenciamento ambiental, tratamento de resíduos, diminuição de ruído em determinados horários, eficiência energética, controle de poluição, entre outros.

O transporte de carga aérea nos aeroportos gera um do fluxo de informações que são necessárias a identificação, recebimento, circulação, liberação e despacho de mercadorias, além de vários agentes envolvidos, entre eles a Receita Federal do Brasil (RFB), INFRAERO, Agência Nacional de Aviação Civil (ANAC), Agência Nacional de Vigilância Sanitária (ANVISA), Ministério da Agricultura (MAPA), Companhias Aéreas e Rodoviárias, Comissão Nacional de Energia Nuclear (CNEN), Comando da Aeronáutica (COMAER) e Departamento de Controle do Espaço Aéreo (DECEA), despachantes aduaneiros, agentes de carga, entre outros. Departamento de Policia Federal (DPF), de Polícia Civil (DPC), de Polícia Militar (DPM), Receita Federal (RF), Secretarias Estaduais da Fazenda e do Planejamento, Superintendência Federal de Agricultura, Serviço de Gestão da Vigilância Agropecuária (VIGIAGRO), Defesa Civil; e indiretamente a Organização Internacional da Aviação Civil (ICAO), Associação Internacional do Transporte Aéreo (IATA), entre outros.

O fluxo da informação no ato da importação e exportação no Brasil envolve armazenamento de dados em sistemas informatizados como o Sistema de Gerenciamento e Manifesto de Carga (MANTRA) que integra o Sistema Integrado de Comércio Exterior (SISCOMEX), ambos da Receita Federal e desenvolvidos pelo Serviço Federal de Processamento de Dados (SERPRO) e o Sistema de 
Gerenciamento de Carga (TECAPLUS), da INFRAERO. O arquivamento documental segue uma padronização determinada pelos organismos internacionais de aviação civil, pelo Ministério da Fazenda e Planejamento, pela ANAC, BACEN, entre outros. A descrição do tipo e a natureza das mercadorias a serem transportadas acarretarão uma variedade de formas de tratamento da carga - que muitas das vezes precisam armazenamento e capatazia diferenciados e condições especiais de guarda; como em câmaras frigoríficas, cofres blindados, terminais especiais de cargas perigosas, além das diferentes formas de tributação pela Fazenda Brasileira.

No Brasil o sistema de aviação civil é composto pelo Conselho Nacional de Aviação Civil (CONAC), COMAER, ANAC, e INFRAERO. A atividade envolve os serviços de administração aeroportuária, serviços de policiamento, controle do tráfego aéreo, fiscalização aduaneira, fitossanitária, agropecuária e aeroviária; e demais elos que atuam comercialmente.

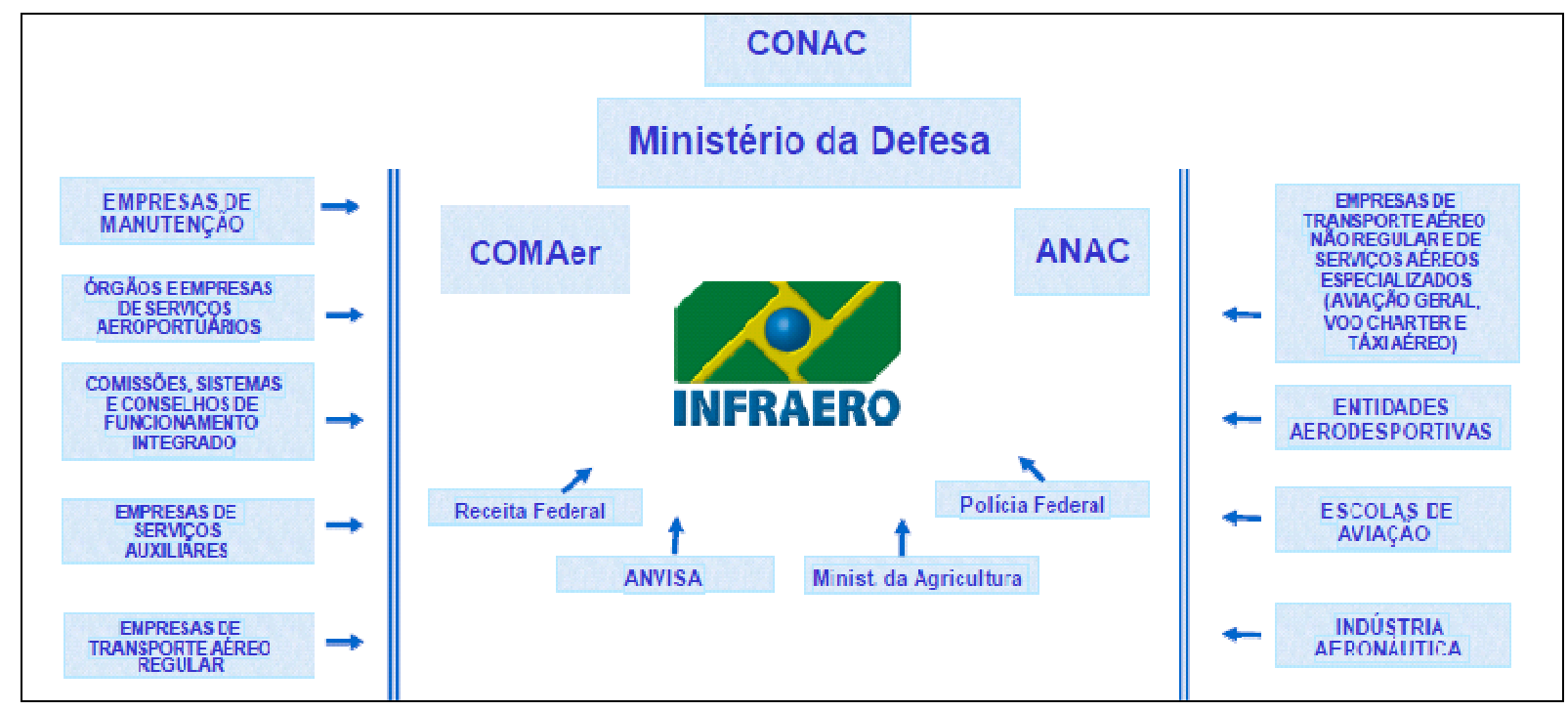

Figura 6: Elos que compõem a Aviação Civil Brasileira Fonte: INFRAERO, 2010.

A interface operacional dos aeroportos é composta por vários órgãos que juntamente com a INFRAERO, regulamenta e controla as atividades aeroportuárias. Integra também o ambiente aeroportuário os hangares de aeronaves, companhias aéreas, as empresas auxiliares do transporte aéreo (Esatas), agências de viagens e turismo, usuários, visitantes, funcionários, passageiros, despachantes de cargas, empresas importadoras e exportadoras, tripulações, distribuidoras de combustível, bancos, Empresa Brasileira de Correios e Telégrafos (ECT), empresas comerciais (livrarias, concessionárias, cooperativas de táxi, cafés, restaurantes, shoppings, 
farmácias), empresas de ônibus e a vizinhança ao sítio aeroportuário.

A ANAC é uma autarquia especial, com independência administrativa, personalidade jurídica própria, patrimônio e receitas próprias para executar atividades típicas da Administração Pública, que requerem, para seu melhor funcionamento, gestão administrativa e financeira descentralizada. Criada pela Lei $\mathrm{n}^{\circ}$ $11.182 / 2005$, e regulamentada pelo Decreto $n^{\circ} 5.731 / 2006$. Suas principais atribuições são: outorgar concessões de serviços aéreos e de infraestrutura aeronáutica e aeroportuária; regular essas concessões; representar o Brasil em convenções, acordos, tratados e atos de transporte aéreo internacional com outros países ou organizações internacionais de aviação civil; aprovar os planos diretores dos aeroportos; compor, administrativamente, conflitos de interesse entre prestadores de serviços aéreos e de infraestrutura aeronáutica e aeroportuária (arbitragem administrativa); estabelecer o regime tarifário da exploração da infraestrutura aeroportuária; contribuir para a preservação do patrimônio histórico e da memória da aviação civil e da infraestrutura aeronáutica e aeroportuária; reprimir e sancionar infrações quanto ao direito dos usuários; ampliar suas atividades na atuação em defesa do consumidor; regular as atividades de administração e exploração de aeródromos exercida pela INFRAERO. (ANAC 2010).

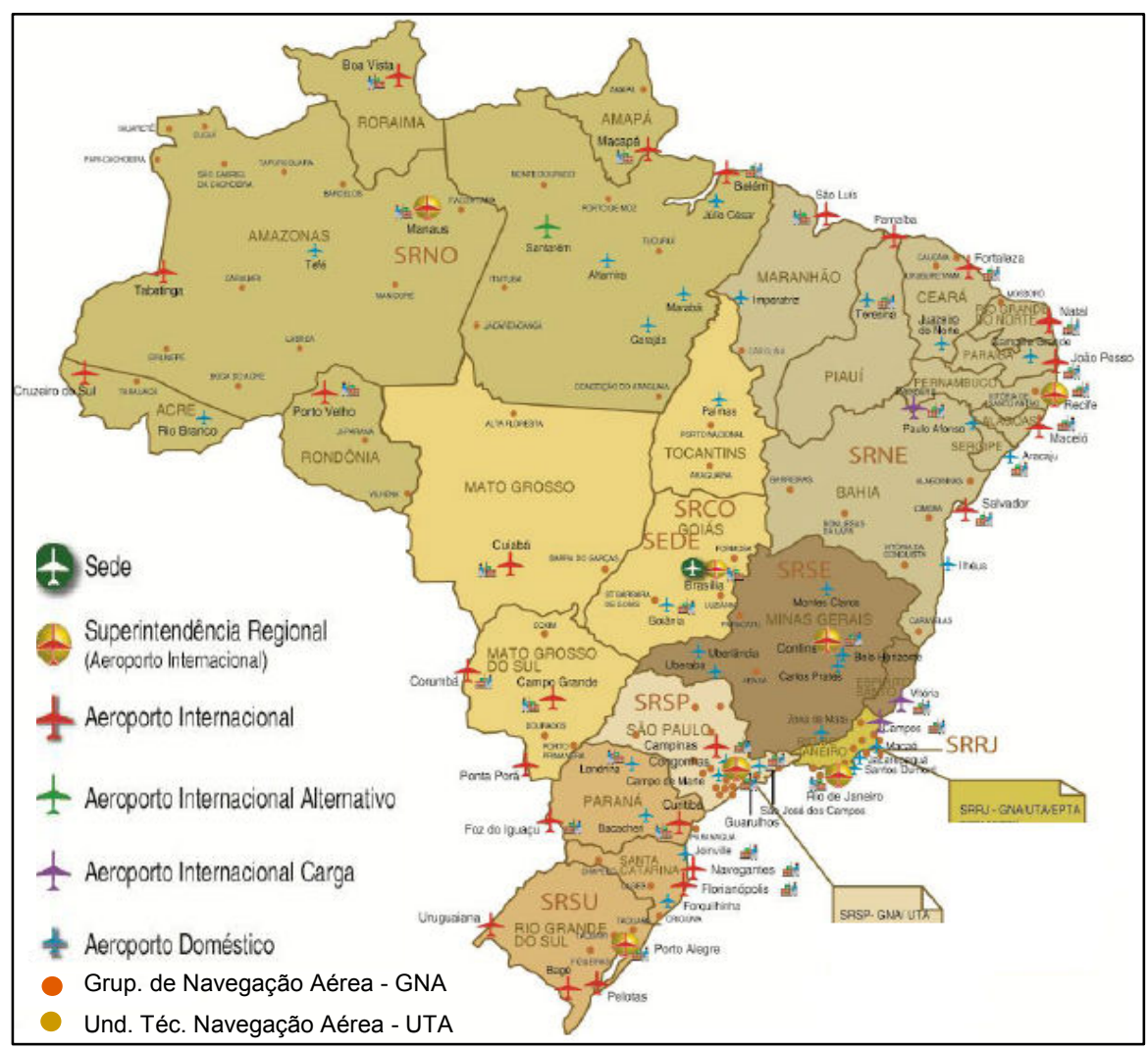

Figura 7: Mapa da rede de aeroportos INFRAERO.

Fonte: INFRAERO, 2010. 
A infraestrutura dos aeroportos brasileiros está sob a responsabilidade da INFRAERO, que opera 67 aeroportos, 68 Grupamentos de Navegação Aérea (GNAs), 34 Terminais de Logística de Carga (TECA) e mantém 50 Unidades Técnicas de Navegação Aérea (UTAs)

A natureza das atividades da empresa é pública, dotada de personalidade jurídica de direito privado, vinculada ao Ministério da Defesa, com sede na capital federal (Brasília) e atuação em todo território nacional. Criada pela Lei N ${ }^{\circ} 5862$ $12 / 12 / 1972$, tem por finalidade implantar, administrar, operar e explorar industrial e comercialmente a infraestrutura aeroportuária e de apoio à navegação aérea, prestar consultoria e assessoramento em suas áreas de atuação e na construção de aeroportos, bem como realizar quaisquer atividades correlatas ou afins, que lhe forem atribuídas pelo Ministério da Defesa. Transitaram nos aeroportos da rede em 2009 128,1 milhões de passageiros, em 2,3 milhões de pousos e decolagens de aeronaves nacionais e estrangeiras, o que corresponde a cerca de $97 \%$ do movimento do transporte aéreo regular no Brasil. A movimentação de carga nacional e internacional nos Terminais de Logística de Carga superou a marca de meio milhão de toneladas anuais. Entre o período de 1997 e 2008 no Brasil, houve um aumento de $105 \%$ na relação quantidade passageiro/população. De 55 milhões para 128 milhões de passageiros/ano, ou de 0,3 para 0,6 pax/habitante.

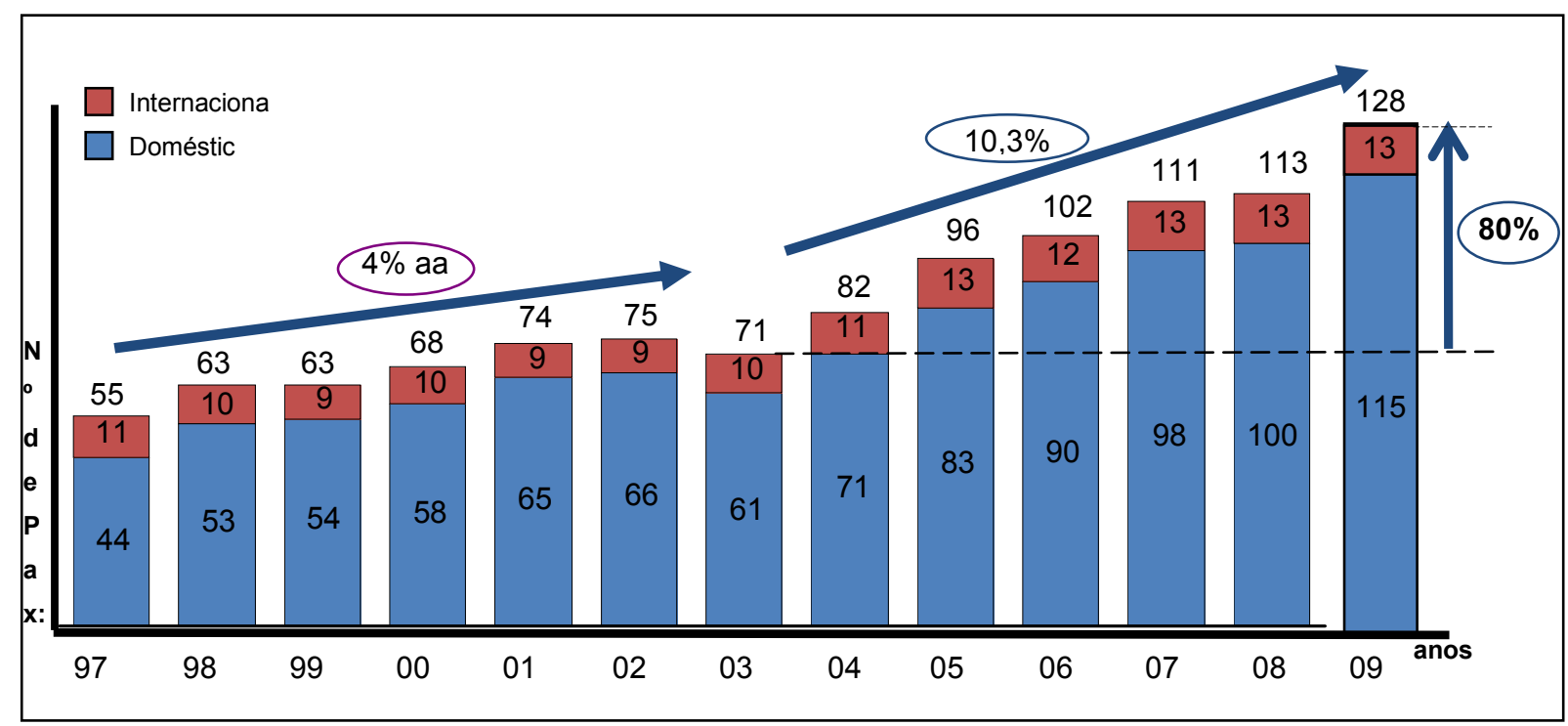

Figura 8: Demanda histórica de passageiros no Brasil

Fonte: INFRAERO, 2009

A situação do Brasil é promissora em relação ao restante do mundo. Segundo o Airport Council International (ACl), o crescimento acumulado no fluxo de 
passageiros no mundo foi $35 \%$, enquanto no Brasil foi de $59 \%$. Dados comparativos entre os anos de 2008 e 2009 demonstram que no Brasil houve um crescimento de $11,6 \%$ no fluxo de passageiros, enquanto no mundo houve um decréscimo de $1,8 \%$.

Os principais elementos que compõem a infraestrutura aeroportuária são: comunicação visual; sistema de som; sistema informativo de vôo; conforto (arquitetura, temperatura, ruído, iluminação e ambientação); sanitários; limpeza; transporte de superfície e pontes de embarque; pessoal especializado; capacidade de operação (pistas, pátio, salas de embarque e desembarque); disponibilidade de facilidade, sistemas e recursos naturais; serviços especiais (atendimento emergencial, segurança); serviços de apoio ao passageiro e carga (táxi, estacionamento, locadoras, paletização de carga, lojas, opções para alimentação, vestuário, bancos e câmbio), entre outros. (INFRAERO, 2010).

A estrutura organizacional da INFRAERO divide-se em processos finalísticos: área Comercial, Operações Aeronáuticas, Segurança Aeroportuária, Logística de Carga e Atendimento ao Público e processos de apoio: área de Meio Ambiente, Financeira, Planejamento e Gestão, Auditoria Interna, Tecnologia da Informação, Manutenção, Jurídica, Administrativa, Engenharia e Ouvidoria.

O Brasil é um país em crescente desenvolvimento econômico e com previsões otimistas para os próximos anos. O fato de sediar a Copa do Mundo de Futebol em 2014 e as Olimpíadas em 2016 demandará investimentos expressivos em infraestrutura aeroportuária para aumentar a capacidade dos Terminais de Passageiros e, em alguns casos, a ampliação dos Terminais de Carga. 


\section{MÉTODOS E TÉCNICAS DE PESQUISA}

Este trabalho foi fundamentado por meio de pesquisa exploratória quantitativa e qualitativa, com o objetivo de compreender a dinâmica da logística aérea internacional e especificamente a importância do Distrito Federal na cadeia logística do comércio exterior, familiarizando o leitor com a problemática levantada e o aprimoramento do tema; buscando construir hipóteses e juízos de valor.

\subsection{Tipo e descrição geral da pesquisa}

A abordagem da pesquisa foi mista, utilizando os métodos: exploratório quantitativo e descritivo qualitativo. Foi realizada por meio de levantamentos de dados secundários junto a órgãos e organismos nacionais e internacionais relacionados ao comércio exterior, transporte de carga aérea e logística; e pesquisas bibliográficas em livros da área de logística e transporte, comércio exterior, anuários estatísticos, trabalhos acadêmicos, artigos e periódicos especializados.

Nos capítulos iniciais foram abordados temas importantes relacionados a administração da produção, logística de carga, inovação, comércio exterior e termos técnicos que envolvem as importações e exportações, de forma a proporcionar ao leitor fundamentação teórica para os capítulos específicos que tratam do mercado internacional de carga aérea no Brasil. A bibliografia sobre o tema é limitada no país devido a maior importância dada aos setores rodoviário, marítimo e ferroviário, sendo necessários a correlação entre anuários e dados estatísticos das organizações nacionais e internacionais relacionadas ao tema.

Foram coletadas informações em relatórios contábeis da rede interna de dados (intranet) da INFRAERO, da Gerência de Logística do SBBR, anuários estatísticos e no sistema de gerenciamento de carga da INFRAERO - TECAPLUS. Relatórios da ANAC, ICAO, TIACA e ACl.

A pesquisa qualitativa foi realizada com a coleta de dados primários junto aos gestores ligados diretamente a atividade de Logística de Carga do Aeroporto Internacional de Brasília, com o método de entrevista dirigida. 


\subsection{Caracterização do Setor de Cargas do Aeroporto de Brasília}

A pesquisa foi realizada na INFRAERO, especificamente na Gerência de Logística de Carga (BRLC) do AIB-PJK. Subordinada a Superintendência Regional do Centro Oeste, a Gerência tem como atribuições principais: representar a empresa como depositário-fiel do recinto alfandegado de Brasília, bem como gerir as atividades de recebimento, manuseio, armazenamento, conservação e entrega das cargas importadas e exportadas aos transportadores, clientes ou representantes legais; analisar as necessidades dos Terminais de Logística de Carga - TECA, no que diz respeito a instalações, equipamentos e pessoal, em face da demanda atual e projetada, propondo à superintendência as medidas cabíveis. Foram levantados os dados referentes aos anos 2006 a 2009 de forma a identificar os efeitos da crise financeira em 2008, no fluxo logístico do TECA-BR.

O AIB-PJK foi Inaugurado oficialmente em 03 de maio de 1957, com um terminal de passageiros de madeira - sendo utilizado este até 1971, e uma pista de pouso projetada para $3.200 \mathrm{~m}$, mas construída parcialmente com $2.400 \mathrm{~m}$. A partir de 1990 começa o processo de modernização do aeroporto de forma a atender a crescente evolução das operações de pousos e decolagens, tanto de aerovaves de passageiros (Combi e Full pax), cargueiros (All Cargo) e da aviação geral caracterizada por vôos charters e aeronaves de pequeno porte, o qual é o primeiro em movimentação no Brasil com 28.851 operações entre pouso e decolagens, o que corresponde a $17,77 \%$ da movimentação do aeroporto; como também do crescimento da importação de insumos de valor agregado pelo modal aéreo. O AIBPJK possui um sítio aeroportuário com área de $28.995 .153 \mathrm{~m}^{2}$, sendo $80.000 \mathrm{~m}^{2}$ ocupados pelo Terminal de Passageiros principal e adjacências e $3.200 \mathrm{~m}^{2}$ ocupados pelo Terminal de Passageiros 2 (Aviação Geral), e o restante por uma área livre potencialmente a ser explorada para ampliação do aeroporto e até mesmo um parque industrial interligado ao modal aéreo. Em 2005 é inaugurada a segunda pista de pouso/decolagens com $3.300 \mathrm{~m}$ de comprimento. Atualmente tem capacidade para receber 10.000 .000 pax/ano, sendo disponibilizadas 40 posições para aeronaves de médio e grande porte e 20 posições para as de pequeno porte; estacionamento com 1.400 vagas para veículos, ; uma seção de Seção de Contra Incêndio com corporação composta por 91 bombeiros e 7 carros de combate ao 
fogo, um complexo logístico de $10.961 \mathrm{~m}^{2}$ - sendo $6.803 \mathrm{~m}^{2}$ destinados a armazenagem em 06 terminais com capacidade para 250 toneladas: 01 armazém para carga perigosa , 03 para carga importada - incluindo área para perdimento, 01 para carga doméstica, 07 câmaras frias, 01 cofre com 20m². (INFRAERO, 2010).

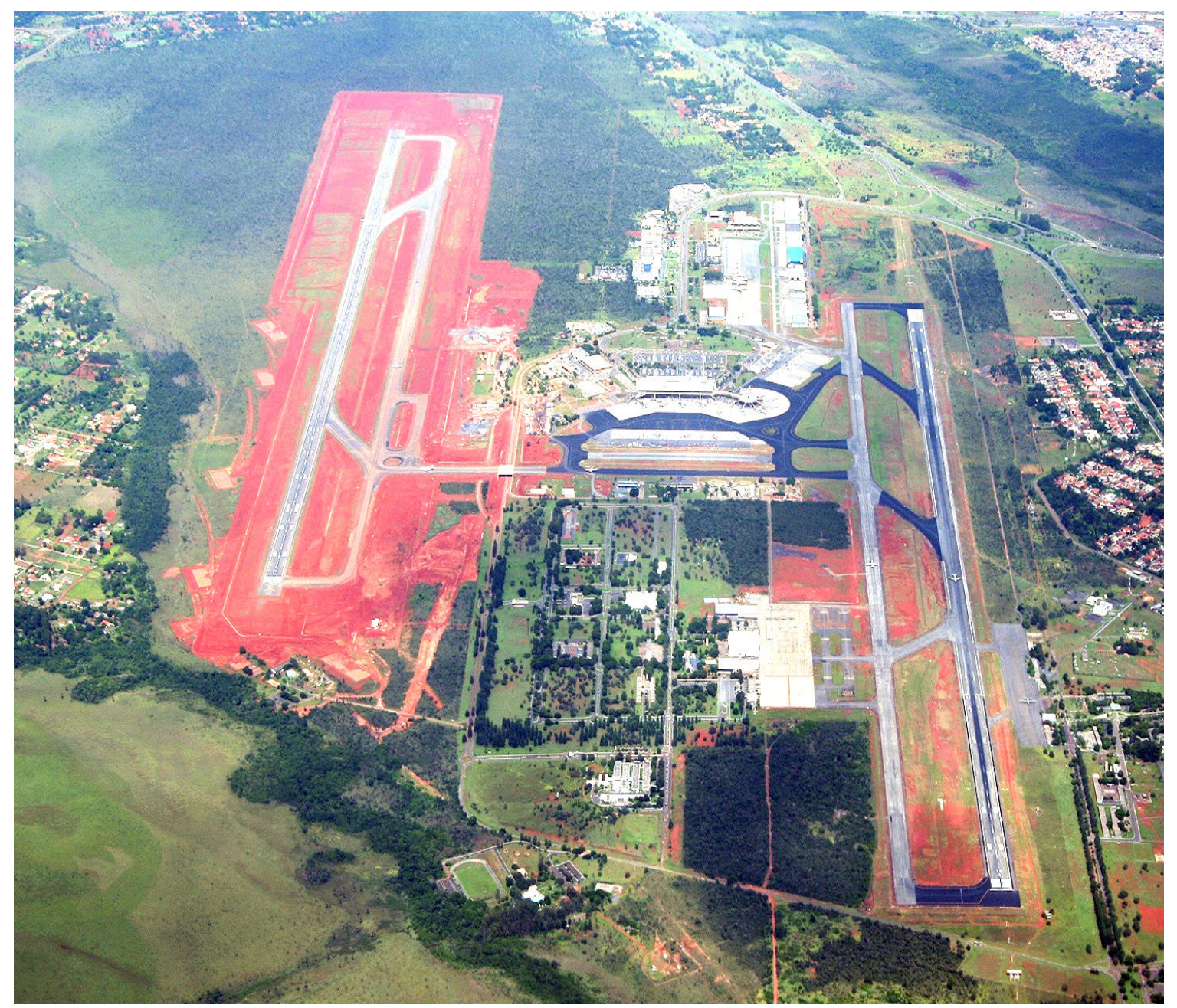

Figura 9: Imagem aérea do sítio aeroportuário de Brasília.

Fonte: INFRAERO, 2008.

Com a abertura Brasileira ao mercado externo no início da década de $90 \mathrm{com}$ o governo Collor o fluxo de cargas importadas cresceu. Posteriormente, com o Plano Real, houve um maior acesso das classes econômicas $C$ e $D$ ao transporte aéreo, que vem optanto cada vez mais por este modal em detrimento do rodoviário. É importante salientar que a utilização do transporte aéreo civil está diretamente ligada ao PIB de um país. Países com maiores PIBs como os das nações desenvolvidas, apresentam um fluxo de passageiros muitos superiores aos das nações em desenvolvimento. 


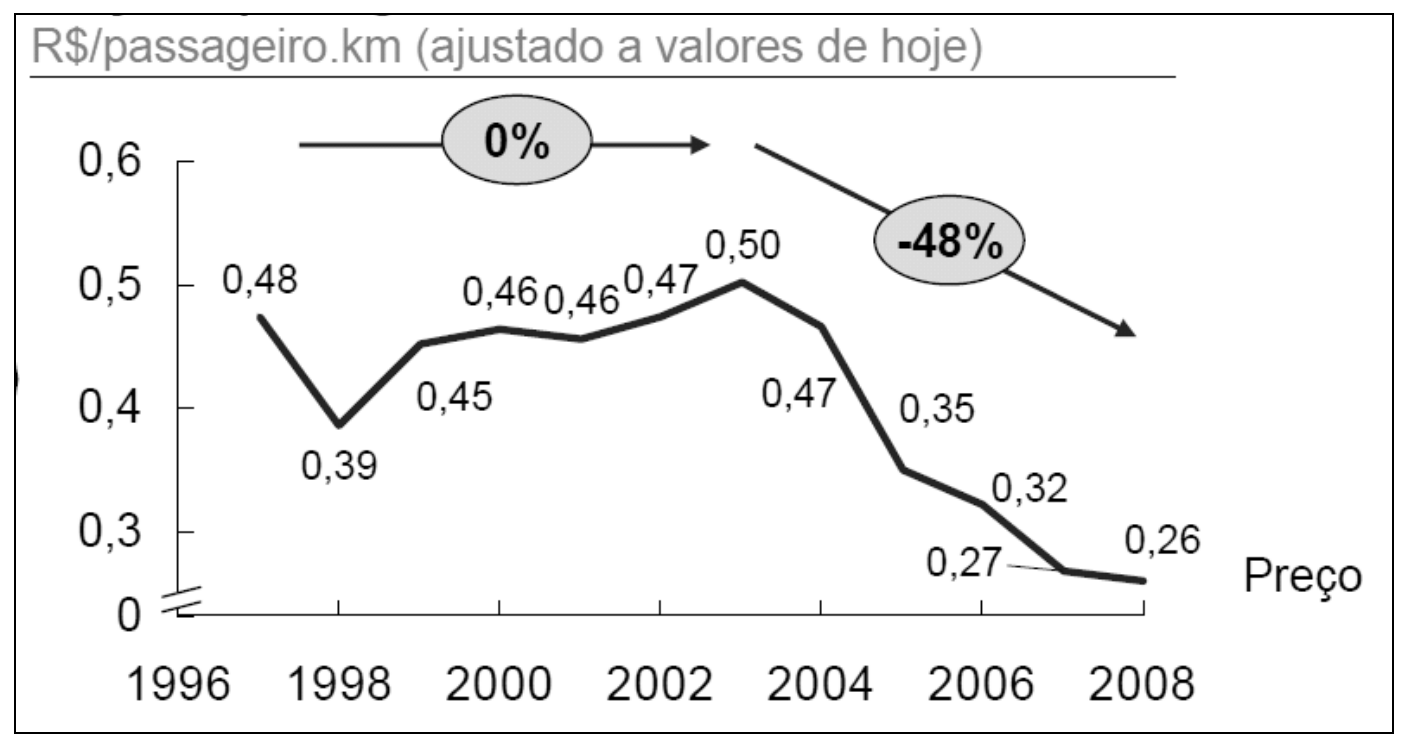

Figura 10: Evolução do Preço da passagem aérea no Brasil Fonte: BNDES 2010.

Essa redução nos preços é devida principalmente pelo crescimento acentuado do PIB a partir de 2003, pelo aumento da concorrência no setor de transporte aéreo e liberação tarifária.

\subsection{Participantes do estudo}

A pesquisa qualitativa foi realizada com gestores do Setor de Logística do Aeroporto Internacional de Brasília, correspondendo a uma amostra de 10 indivíduos ou $91 \%$ da população, que ocupavam naquele momento os seguintes cargos: Superintendente do Aeroporto, Gerente de Logística, Coordenador de Importação e Exportação, Coordenador de Facilitação e Atendimento ao Cliente, Coordenador da Carga Nacional, 04 Encarregados de Atividades do Terminal de Carga e o Coordenador de Logística da Superintendência Regional Centro-Oeste (SRCO).

\subsection{Caracterização dos instrumentos de pesquisa}

O Instrumento de pesquisa utilizado foi o de entrevista dirigida, aplicada aos gestores ocupantes de cargos de confiança ligados diretamente a atividade de logística, constando doze perguntas agrupadas em 05 variáveis distintas, 
objetivando identificar existência de falhas no processo administrativo, pontos a serem melhorados na atividade e as expectativas em relação à construção do Novo Terminal de Carga. Resumidamente, foram questionados os seguintes pontos aos respondentes: evolução da logística de Carga Internacional e Nacional e visão futura; infraestrutura física e tecnológica do TECA-BR; aspectos administrativos da Gerência de Logística; avaliação das atividades de recepção, armazenagem, capatazia e despacho de carga; avaliação dos órgãos anuente e stakeholders; expectativas em relação ao momento de ampliação do Aeroporto de Brasília; mercado de carga no DF e privatização e abertura de capital da INFRAERO. Vide Apêndice A.

\subsection{Procedimentos de Coleta e Análise dos Dados}

O procedimento de coleta de dados primários foi a aplicação da entrevista em questão, no mês de julho de 2010, no Aeroporto Internacional de Brasília - Lago Sul/DF, com aproximadamente 30 minutos de duração para cada respondente, sendo gravado em meio eletrônico as respostas e posteriormente tabuladas os pontos mais relevantes. Antes da divulgação dos dados as respostas tabuladas foram encaminhadas aos respondentes para a devida ciência e concordância na divulgação. As entrevistas dirigidas servirão como complemento às informações estatísticas e obtenção da visão profissional e experiências dos entrevistados, subsidiando a análise e discussão dos resultados da pesquisa.

Os dados quantitativos secundários coletados serviram de base na elaboração de gráficos e tabelas para demonstrar a movimentação de carga e a viabilidade econômica do Terminal de Cargas do Aeroporto de Brasília. 


\section{RESULTADOS E DISCUSSÃO}

A apresentação da estrutura aeroportuária foi baseada em documentos oficiais dos órgãos atuantes no setor, tratados de forma quantitativa e demonstrados principalmente por meio de tabelas e gráficos, de forma a detalhar a logística de carga em seus aspectos de infraestrutura, financeiros e mercadológicos. A pesquisa descritiva qualitativa foi apresentada no formato de tabela e objetiva relatar a visão dos gestores no que diz respeito ao quadro atual da Logística no TECA-BR e as expectativas futuras em relação aos investimentos a serem realizados nos próximos anos.

\subsection{Apresentação Documental da Estrutura Aeroportuária}

Já foram iniciados os projetos de reforma e ampliação do Terminal de Passageiros (TPS), Complexo Logístico de Carga e acesso viário do aeroporto (APÊNDICE D). No atual TPS haverá melhorias em aproximadamente $8.000 \mathrm{~m}^{2}$, incluindo saguão, salas de embarque e desembarque, check-in, controles de entrada de passageiros (raios- $X$ ), meio fio de desembarque e a área de bagagens. Com a ampliação serão acrescidos cerca de $80.000 \mathrm{~m}^{2}$, o que permitirá atender a um movimento de 25 milhões de passageiros por ano, estimado para ser atingido em 2018 (INFRAERO 2010).

Em julho do presente ano começaram as obras no corpo central do aeroporto do Módulo Operaciona,I que aumentará a área de embarque consideravelmente. Devido a sua localização estratégica no centro geográfico e político do Brasil, o AIBPJK é considerado um centro logístico estratégico, juntamente com Guarulhos e Congonhas, ou seja, ponto de concentração para transferências de passageiros (Hub), apresentado $37 \%$ das suas operações em conexões, $30 \%$ de embarques e $33 \%$ de desembarques. É o terceiro no país em fluxo de aeronaves e passageiros e o quinto na movimentação de cargas. Tem como principais destinos: São Paulo $(11,5 \%)$; Rio $(7,1 \%)$, Fortaleza $(4,2 \%)$, Goiânia $(7,1 \%)$ e Belo Horizonte $(4,4 \%)$ e 
principais origens: Palmas $(8,3 \%)$, São Luiz $(5,2 \%)$, Rio Branco $(7,1 \%)$, São Paulo $(7,1 \%)$ e Goiânia (5,2\%). (BNDES 2010).

Tabela 3: Os Dez Maiores em Movimento de Passageiros em 2009

\begin{tabular}{|c|r|r|r|}
\hline \multicolumn{4}{|c|}{ PASSAGEIROS (milhões) } \\
\hline SIGLA & \multicolumn{1}{|c|}{ DOM. } & \multicolumn{1}{|c|}{ INT. } & \multicolumn{1}{c|}{ TOTAL } \\
\hline SBGR & $13.268,1$ & $8.459,5$ & $21.727,6$ \\
\hline SBSP & $13.699,7$ & 0,0 & $13.699,7$ \\
\hline SBBR & $12.056,6$ & 157,2 & $12.213,8$ \\
\hline SBGL & $9.215,5$ & $2.613,2$ & $11.828,7$ \\
\hline SBSV & $6.738,7$ & 314,1 & $7.052,7$ \\
\hline SBCF & $5.371,6$ & 245,5 & $5.617,2$ \\
\hline SBPA & $5.256,1$ & 351,6 & $5.607,7$ \\
\hline SBRF & $5.042,3$ & 208,3 & $5.250,6$ \\
\hline SBRJ & $5.099,5$ & 0,2 & $5.099,6$ \\
\hline SBCT & $4.764,8$ & 88,9 & $4.853,7$ \\
\hline Sub total & $\mathbf{8 0 . 5 1 2 , 9}$ & $\mathbf{1 2 . 4 3 8 , 5}$ & $\mathbf{9 2 . 9 5 1 , 3}$ \\
\hline Demais & $\mathbf{3 4 . 4 8 9 . 5 3 8}$ & $\mathbf{6 9 4 . 7 5 6}$ & $\mathbf{3 5 . 1 8 4 . 2 9 4}$ \\
\hline
\end{tabular}

Fonte: Adaptado de Opnet; INFRAERO, 2010.

A Movimentação de Cargas nos aeroportos engloba a INFRAERO, Correios, Cias Aéreas e outros.

Tabela 4: Os dez maiores em Movimento de Carga em 2009

\begin{tabular}{|c|r|r|r|r|r|}
\hline & \multicolumn{2}{|c|}{ CARGA AEREA (Ton) } & \multicolumn{2}{c|}{ Courier (Ton) } \\
\hline SIGLA & \multicolumn{1}{|c|}{ DOM. } & \multicolumn{1}{c|}{ INT. } & \multicolumn{1}{c|}{ TOTAL } & SIGLA & TOTAL \\
\hline SBGR & $139.878,7$ & $211.908,9$ & $351.787,6$ & SBGR & $43.064,8$ \\
\hline SBKP & $8.784,4$ & $183.523,1$ & $192.307,5$ & SBGL & $33.160,9$ \\
\hline SBEG & $90.382,5$ & $44.035,8$ & $134.418,3$ & SBSV & $13.603,2$ \\
\hline SBGL & $23.981,1$ & $56.289,3$ & $80.270,4$ & SBBR & $12.904,2$ \\
\hline SBBR & $40.183,6$ & 816,8 & $41.000,4$ & SBEG & $11.206,9$ \\
\hline SBRF & $36.015,3$ & $4.384,9$ & $40.400,2$ & SBRF & $9.680,8$ \\
\hline SBFZ & $36.217,8$ & $1.502,8$ & $37.720,6$ & SBPA & $8.955,4$ \\
\hline SBSV & $28.984,0$ & $7.996,5$ & $36.980,6$ & SBCT & $7.595,3$ \\
\hline SBSP & $29.306,0$ & 0,0 & $29.306,0$ & SBFZ & $5.935,3$ \\
\hline SBCT & $8.940,3$ & $14.366,7$ & $23.307,1$ & SBBE & $5.782,4$ \\
\hline Subtotal & $\mathbf{4 4 2 . 6 7 3 , 8}$ & $\mathbf{5 2 4 . 8 2 4 , 8}$ & $\mathbf{9 6 7 . 4 9 8 , 6}$ & Subtotal & $\mathbf{1 5 1 . 8 8 9 , 3}$ \\
\hline Demais & $\mathbf{1 3 4 . 2 0 9 . 9 7 3}$ & $\mathbf{1 3 . 0 4 5 . 6 7 9}$ & $\mathbf{1 4 7 . 2 5 5 . 6 5 2}$ & & $\mathbf{2 9 . 6 2 2 . 2 7 0}$ \\
\hline
\end{tabular}

Fonte: Adaptado de Opnet; INFRAERO, 2010.

No que diz respeito a movimentação de cargas e receitas no SBBR, houve um crescimento médio ao longo da década de $4,21 \%$, com algumas oscilações tanto em receita quanto em tonelagem. 


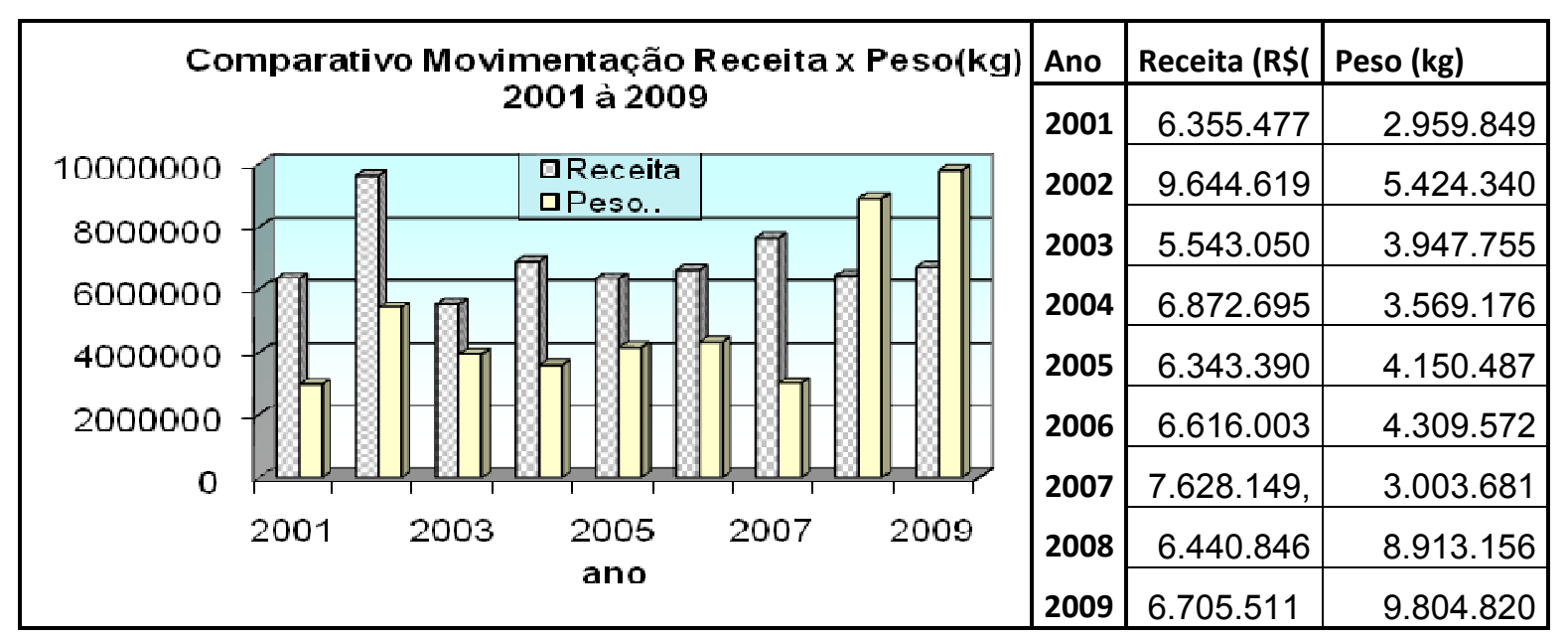

Figura 11: Evolução da carga no SBBR

Fonte: Adaptado de Infranet; INFRAERO, 2010

Em relação à construção do novo complexo logístico de carga, estima-se um investimento no valor $R \$ 41,26$ milhões, passando dos $6.310 \mathrm{~m}^{2}$ atuais para 21.285 $\mathrm{m}^{2}$. Englobando as obras do pátio de aeronaves cargueiras e sistema viário $\mathrm{o}$ montante pode alcançar a ordem de 133,9 milhões.

É de suma importância levar em consideração os fatores que justificam tais investimentos, o nível de rentabilidade, a saturação de terminais e os gargalos logísticos:

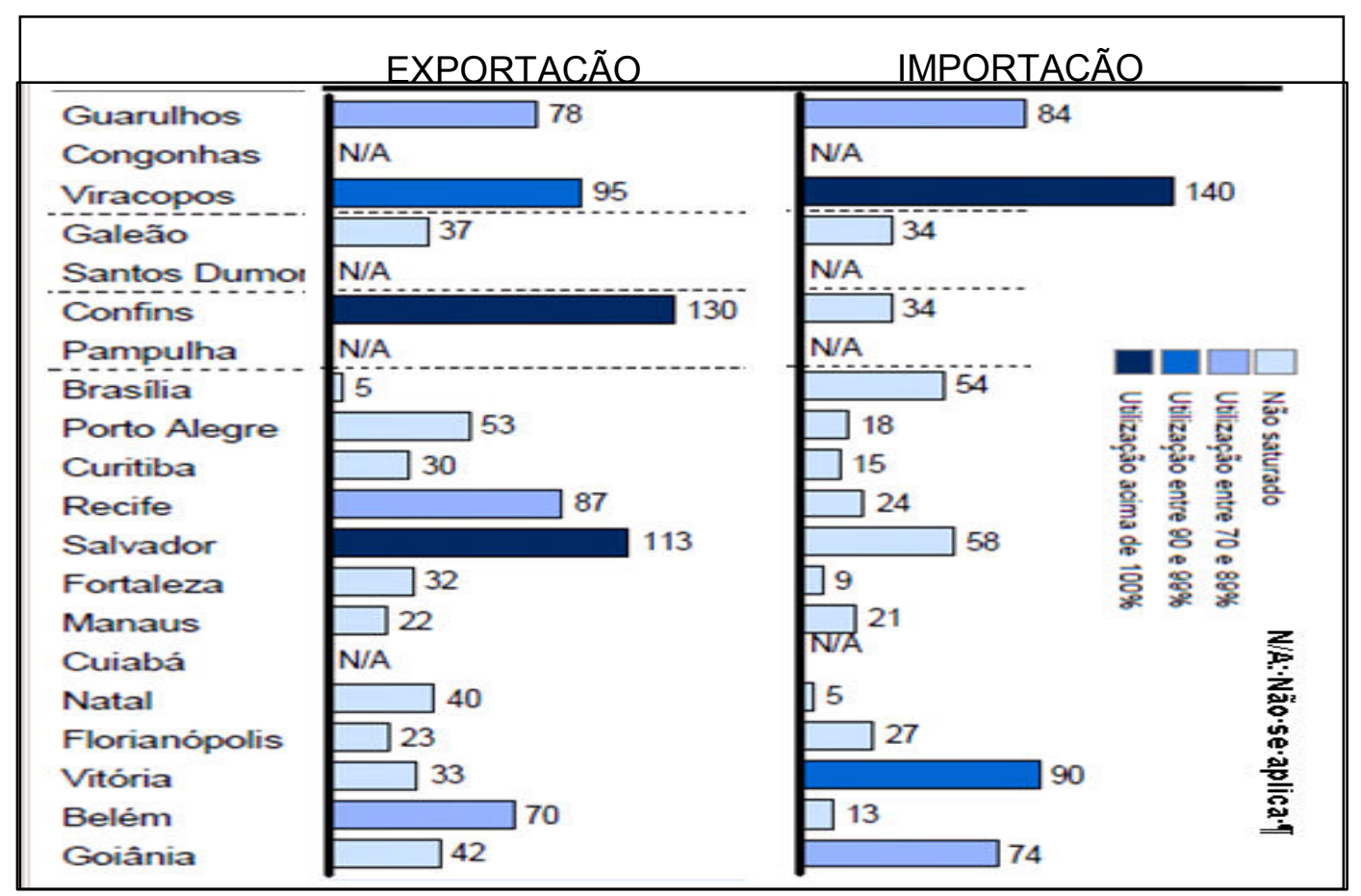

Figura 12 - Capacidade operacional dos TECAs da rede INFRAERO Fonte: Adaptado de ITA; BNDES, 2009. 
O novo complexo visa sanar as deficiências do TECA atual no que diz respeito a espaço para armazenagem, principalmente no armazém de carga doméstica, que em períodos pontuais de maior demanda por celulares atinge a lotação máxima, ressaltando que estas mercadorias corresponde a $80 \%$ da movimentação doméstica. A Carga Nacional possui atualmente uma área de armazenagem de $553 \mathrm{~m}^{2}$, passando para aproximadamente $6.000 \mathrm{~m}^{2}$ no novo complexo logístico. Outra carência é espaço para armazenagem em câmaras frigoríficas, principais gargalos encontrados atualmente. Uma série de serviços e infraestrutura física serão construídos para atender as exigências das agências reguladoras, como por exemplo, área segregada para importação e exportação atualmente são compartilhadas; terminal de carga perigosa atendendo a $100 \%$ dos padrões exigidos, com segregação para diversos tipos de cargas, câmara frigorífica para produtos perigosos, entre outros; área de fumigação para madeira e resíduos; área isolada para cargas vivas (animais); sala de coleta de amostras; sala de manuseio de medicamentos para atender as exigências da ANVISA, climatização de parte do armazém para guarda de cargas entre $15^{\circ}$ e $25^{\circ}$; câmaras frigoríficas com resfriamento mínimo de $80^{\circ}$ negativos - atualmente possui 01 câmara com resfriamento mínimo de $20^{\circ}$ negativos; ampliação da capacidade das câmaras frigoríficas de $427 \mathrm{~m}^{3}$ atuais para aproximadamente $2.000 \mathrm{~m}^{3}$, local apropriado para tratamento e guarda de resíduos sólidos (palets de madeira, plásticos, entre outros); área de canil para Polícia Federal; área para recepção de caminhões e facilitação da desova por meio de esteiras e acesso direto a área climatizada, estacionamento amplo para caminhões, local para guarda coberta de grandes equipamentos como empilhadeiras e tratores, equipamentos de raio-x e pórticos para inspeção entre outras facilidades. (BRLC/SBBR; INFRAERO, 2010.)

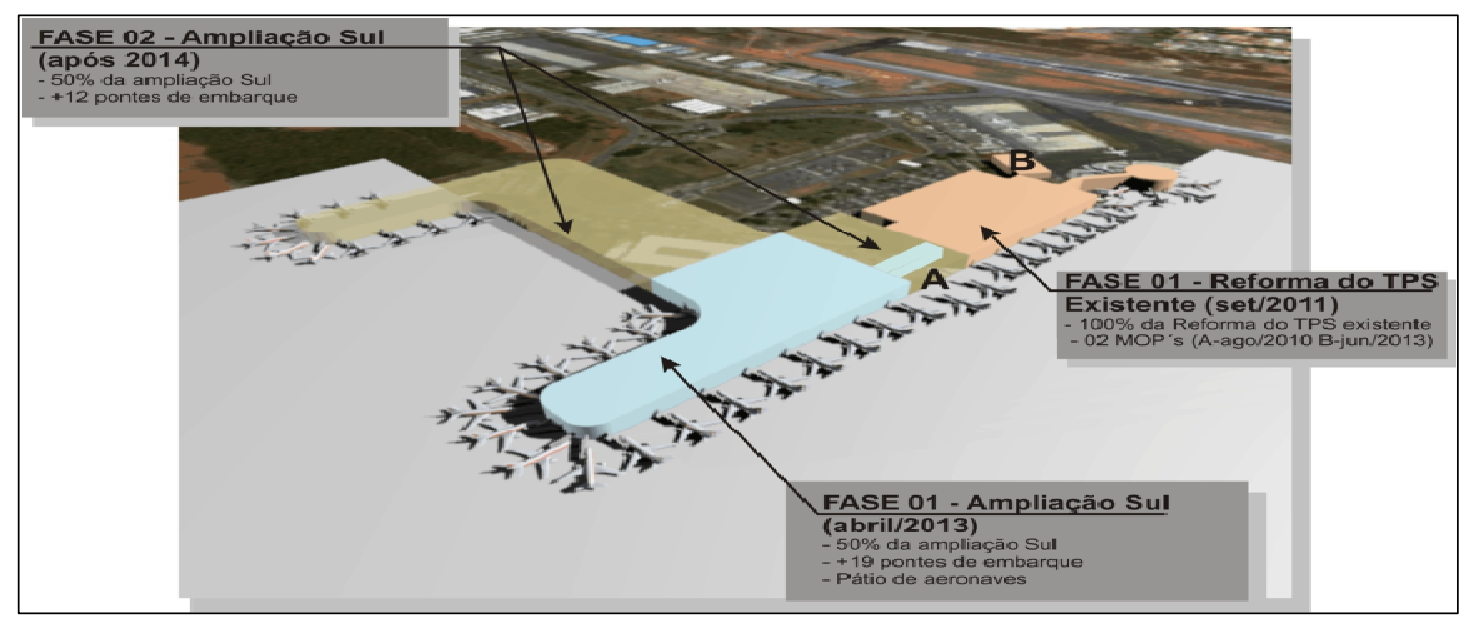

Figura 13: Projeção da reforma e ampliação do SBBR Fonte: http://www.skyscrapercity.com/showthread.php?t=404892\&page=52 
Em termos gerenciais qualquer investimento precisa apresentar viabilidade econômica, e no caso de Brasília não pode ser diferente. Com os mega-eventos que aconteceram no Brasil a partir de 2014 o Governo Federal projeta investimentos na ordem de $\mathrm{R} \$ 6,4$ bilhões, parte proveniente do PAC e outra proveniente da INFRAERO. Até 2030 a estimativa é de investimentos entre $\mathrm{R} \$ 25$ a 34 bilhões, em sua maior parte concentrados entre os anos 2021 e 2030, e aumento do fluxo de pax dos atuais 128 milhões pax/ano para 312 milhões pax/ano em 2030. Segundo dados do BNDES (2010), os investimentos se justificam no caso do aeroporto de Brasília mesmo se não houvesse tais eventos, em virtude do aeroporto apresentar uma estrutura de pátios e pistas saturada, e um terminal de passageiros com capacidade de 10 milhões de passageiros/ano, mas cujo fluxo supera 12 milhões/ano.

Tabela 5: Capacidade operacional dos aeroportos em horários de pico

\begin{tabular}{|l|c|c|}
\hline AEROPORTO & CAPACIDADE & DEMANDA \\
\hline NATAL (RN) & 7 & 8 \\
\hline PAMPULHA (MG) & 5 & 8 \\
\hline CONFINS (MG) & 16 & 19 \\
\hline SANTOS DUMONT (RJ) & 15 & 18 \\
\hline CURITIBA (PR) & 14 & 18 \\
\hline PORTO ALEGRE (RS) & 14 & 20 \\
\hline MANAUS (AM) & 9 & 17 \\
\hline BRASÍLIA (DF) & 36 & 45 \\
\hline CONGONHAS (SP) & 24 & 34 \\
\hline GUARULHOS (SP) & 53 & 65 \\
\hline
\end{tabular}

Fonte: IPEA, 2009. Adaptado de: http://www.diap.org.br

O AIB-PJK interliga diretamente com vôos comerciais os continentes americano e europeu, com as empresas TAP (Bsb-Lisboa), DELTA (Bsb-Atlanta), TAM (Bsb-Buenos Aires), GOL (Bsb-Rosário, Argentina), Lan Peru (Bsb-Lima) que começou operar a partir de julho deste ano, e ainda com previsões de operação de empresas como a America Airlines (Bsb-Miami), além de operações com cargueiros das empresas ABSA, MTA, TOTAL, TAF, BETA, RIO e VARIGLOg; operação de vôos domésticos pelas empresas TAM, GOL, VARIG, OCEANAIR, WEBJET, TAP, TRIP, PASSAREDO, AVIANÇA, SETE Linhas Aéreas e a empresa AZUL, que começou a operar também a partir de julho de 2010. 


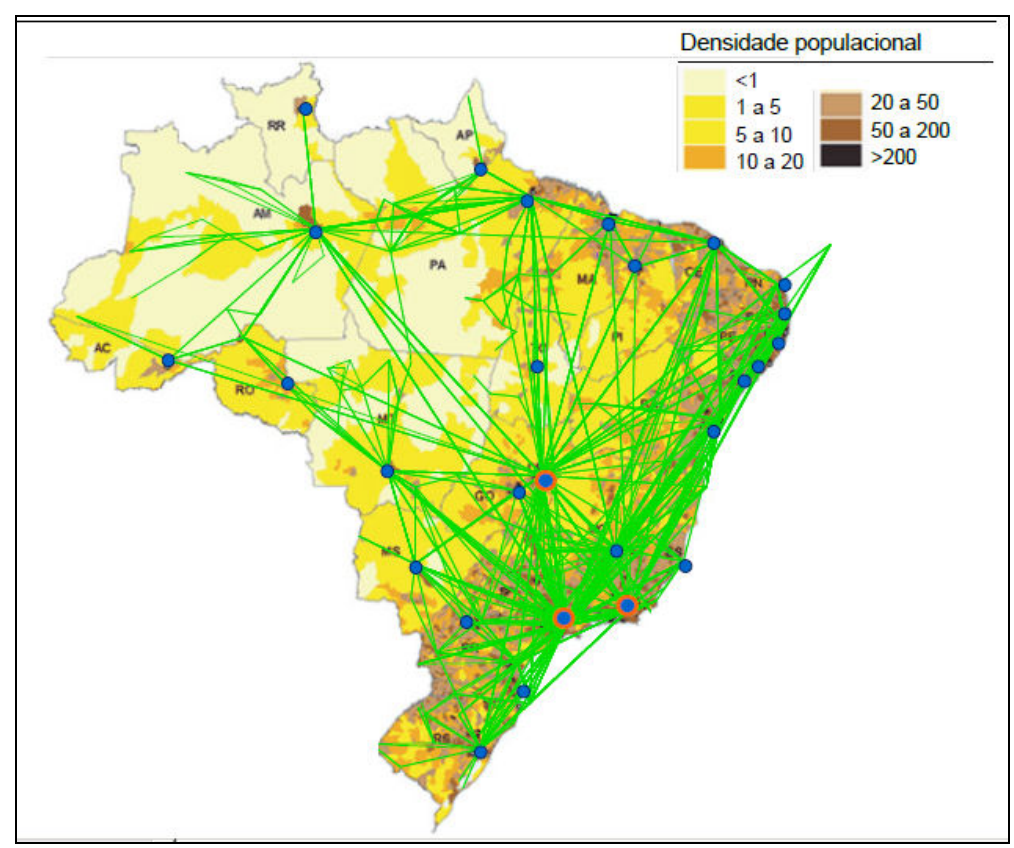

Figura 14: Malha aérea Brasileira - rotas regulares Fonte: BNDES 2010

No que diz respeito a cargas movimentadas pelas companhias aéreas, abrangendo embarque, desembarque e trânsito, temos o seguinte quadro:

Tabela 6: Movimento de cargas pelas Cias Aéreas no SBBR em kg.

\begin{tabular}{l|r|r|r|r|c}
\hline \multicolumn{1}{c|}{ Empresa Aérea } & \multicolumn{1}{c|}{$\mathbf{2 0 0 6}$} & \multicolumn{1}{c|}{$\mathbf{2 0 0 8}$} & $\mathbf{2 0 0 9}$ & ACUMULADO \\
\hline AV. GERAL & 0 & 0 & 168 & 0 & $\mathbf{1 6 8}$ \\
\hline BRA & 1.258 & 2.938 & 0 & 0 & $\mathbf{4 . 1 9 6}$ \\
\hline Delta Air Lines & 0 & 0 & 0 & 3.964 & $\mathbf{3 . 9 6 4}$ \\
\hline Gol & 171.726 & 3.317 .636 & 8.052 .243 & 3.741 .724 & $\mathbf{1 5 . 2 8 3 . 3 2 9}$ \\
\hline Ocean-Air & 2 & 92.592 & 946.148 & 1.512 .807 & $\mathbf{2 . 5 5 1 . 5 4 9}$ \\
\hline Passaredo & 0 & 436 & 525 & 670 & $\mathbf{1 . 6 3 1}$ \\
\hline Sete & 0 & 0 & 0 & 74 & $\mathbf{7 4}$ \\
\hline Skymaster & 88.698 & 0 & 0 & 0 & $\mathbf{8 8 . 6 9 8}$ \\
\hline TAF & 0 & 0 & 0 & 0 & $\mathbf{0}$ \\
\hline TAM & 1.887 .459 & 27.650 .543 & 25.999 .651 & 35.033 .450 & $\mathbf{9 0 . 5 7 1 . 1 0 3}$ \\
\hline Tap & 0 & 87.523 & 100.057 & 640.768 & $\mathbf{8 2 8 . 3 4 8}$ \\
\hline TOTAL & 2 & 330.784 & 0 & 0 & $\mathbf{3 3 0 . 7 8 6}$ \\
\hline TOTAL GERAL & 2.149 .145 & 31.482 .452 & 35.098 .792 & 40.933 .457 & $\mathbf{1 0 9 . 6 6 3 . 8 4 6}$ \\
\hline Trip & 0 & 179 & 0 & 534 & $\mathbf{7 1 3}$ \\
\hline Varig & 1.198 .120 & 985.880 & 2.014 .071 & 15.168 & $\mathbf{4 . 2 1 3 . 2 3 9}$ \\
\hline VarigLog & 88.698 & 942.385 & 0 & 0 & $\mathbf{1 . 0 3 1 . 0 8 3}$ \\
\hline WebJet & 0 & 1.229 & 61.444 & 71.228 & $\mathbf{1 3 3 . 9 0 1}$ \\
\hline Total Geral & 5.585 .108 & 64.894 .577 & 72.273 .099 & 81.953 .844 & $\mathbf{2 2 4 . 7 0 6 . 6 2 8}$ \\
\hline
\end{tabular}

*Obs: dados não fornecidos pela aviação geral e TAF. Alguns Dados podem não condizer com a realidade.

Fonte: Adaptado de Infranet. INFRAERO, 2010. 
Tabela 7: Movimento de aeronaves cargueiras - 10 maiores da Rede em 2009

\begin{tabular}{l|r|r|r|r|r}
\hline \multirow{2}{*}{ Võo } & \multicolumn{4}{|c|}{ Regular e Não Regular } & \\
\cline { 2 - 6 } \multicolumn{1}{c|}{$\begin{array}{c}\text { AEROPORTOS } \\
\text { INTERNACIONAIS }\end{array}$} & Pouso & Decolagem & Pouso & Decolagem & TOTAL \\
\hline SBGR & 3.890 & 3.856 & 72 & 104 & $\mathbf{7 . 9 2 2}$ \\
\hline SBKP & 209 & 174 & 3.122 & 3.163 & $\mathbf{6 . 6 6 8}$ \\
\hline SBEG & 1.625 & 1.556 & 778 & 777 & $\mathbf{4 . 7 3 6}$ \\
\hline SBSV & 1.861 & 1.858 & 45 & 45 & $\mathbf{3 . 8 0 9}$ \\
\hline SBBR & 1.723 & 1.691 & 38 & 34 & $\mathbf{3 . 4 8 6}$ \\
\hline SBGL & 1.436 & 1.395 & 118 & 113 & $\mathbf{3 . 0 6 2}$ \\
\hline SBBE & 1.575 & 1.474 & 2 & 2 & $\mathbf{3 . 0 5 3}$ \\
\hline SBCT & 920 & 915 & 320 & 320 & $\mathbf{2 . 4 7 5}$ \\
\hline SBFL & 1.060 & 1.032 & - & 1 & $\mathbf{2 . 0 9 3}$ \\
\hline SBMQ & 1.033 & 1.057 & - & - & $\mathbf{2 . 0 9 0}$ \\
\hline DEMAIS AEROPORTOS & 12.305 & 12.156 & 282 & 279 & $\mathbf{2 5 . 0 2 2}$ \\
\hline TOTAL DA REDE & $\mathbf{2 7 . 6 3 7}$ & $\mathbf{2 7 . 1 6 4}$ & $\mathbf{4 . 7 7 7}$ & $\mathbf{4 . 8 3 8}$ & $\mathbf{6 4 . 4 1 6}$ \\
\hline
\end{tabular}

Fonte. Adaptado de OPNET. INFRAERO, 2010

A partir da análise do último quadriênio é possível obter um quadro atual da carga aérea em Brasília e os reflexos da crise em 2008. O setor de importação do TECA-BR se destaca pela sua função social devido ao alto fluxo de cargas isentas de tarifação, com destaque a importação pelo Ministério da Saúde de insumos médico-hospitalares, vacinas, preservativos, etc., que abastece o Distrito Federal e distribui a diversos estados brasileiros, além de cargas do Ministério da Justiça, Forças Armadas, Embaixadas, Instituições de Ensino e Pesquisa, Organismos Internacionais, Entidades sem fins lucrativos, entre outros.

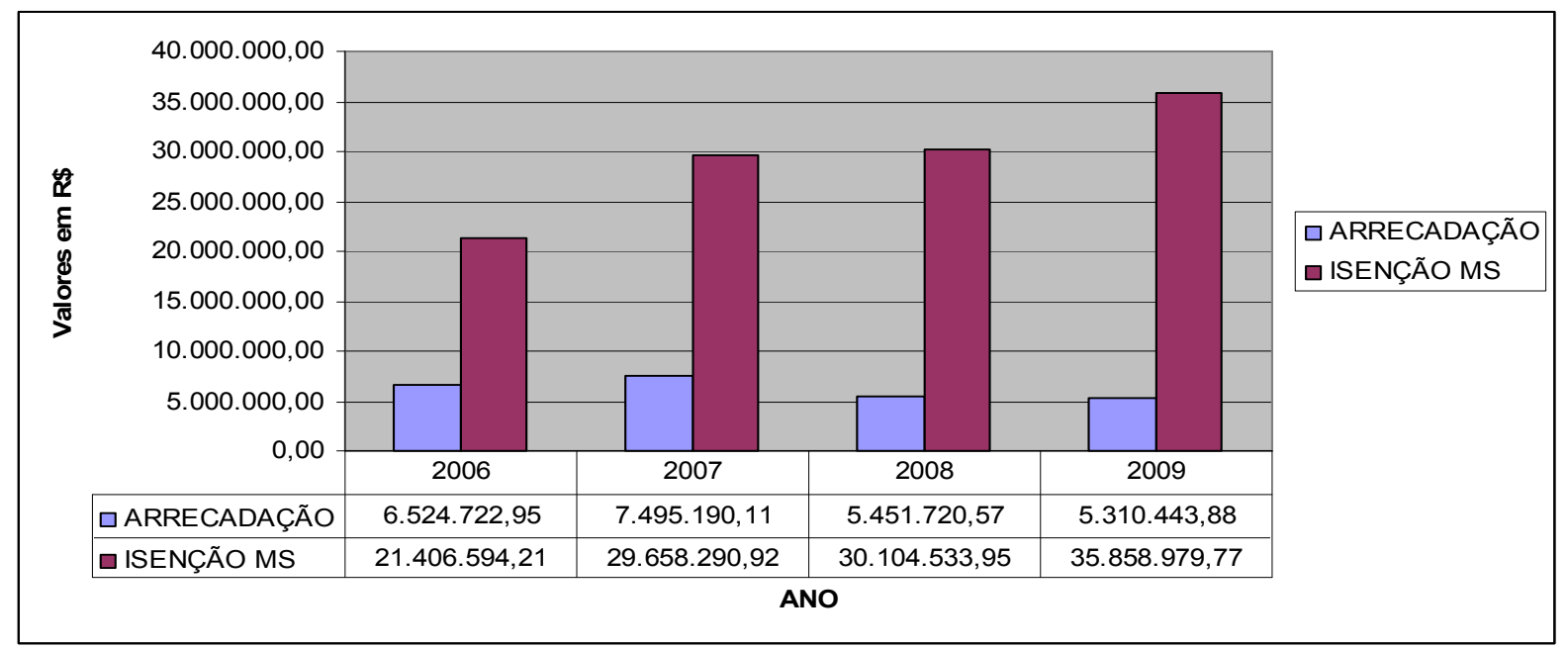

Figura 15: Valor das arrecadações e isenções no SBBR: de 2006 à 2009.

Fonte: BRLC/SBBR, INFRAERO, 2010. 
No que diz respeito à importação não isentas destacam-se os produtos farmacêuticos e de biotecnologia, eletroeletrônicos e eletromecânicos, de segurança, médico-hospitalares, de comissária e aeronáuticos diversos, voltados para pesquisa científica, entre outros. No aeroporto de Brasília as cargas removidas para zona secundária (Porto Seco) são, em sua maioria, importação de produtos farmacêuticos no valor CIF $^{1}$ de R $\$ 75.667 .311,38$ de um total arrecadado em 2009 de $R \$ 1.519 .512 .312,61$, ou seja, 4,98\%. (BRLC/SBBR; INFRAERO, 2010).

Tabela 8: Os 20 maiores importadores do DF em 2009 em tonelagem - TECA-BR

\begin{tabular}{l|c|r|r}
\hline \multicolumn{1}{c|}{ IMPORTADORES } & $\begin{array}{c}\text { Descrição das principais } \\
\text { Mercadorias importadas }\end{array}$ & Peso (ton) & \multicolumn{1}{c}{$\begin{array}{c}\text { \% do } \\
\text { Total }\end{array}$} \\
\cline { 2 - 4 } & Prod. farmacêuticos & $325.031,70$ & 29,74 \\
\hline F.B.M. IND. FARMACEUTICA & Prod. farmacêuticos & $120.216,00$ & 11,00 \\
\hline BIOSINTETICA & Biotecnologia & $69.312,20$ & 6,34 \\
\hline EMBRAPA & Pesquisa científica e tecnológica & $43.594,90$ & 3,99 \\
\hline CNPq & Equip. de segurança & $35.518,60$ & 3,25 \\
\hline MINISTÉRIO DA JUSTIÇA & Diversos & $30.761,00$ & 2,81 \\
\hline LOGSERVE (Porto Seco do DF) & Prod. farmacêuticos & $27.678,70$ & 2,53 \\
\hline EMS S/A & Prod. farmacêuticos & $26.465,00$ & 2,42 \\
\hline MEIZLER BIOPHARMA S/A & Equip. de telecomunicações & $25.694,60$ & 2,35 \\
\hline GVT & Prod. Médico-hospitalares & $24.823,00$ & 2,27 \\
\hline PIONEIRAS SOCIAIS (Rede Sarah) & Engenharia e equip. eltromecânicos & $22.630,30$ & 2,07 \\
\hline ENERG POWER S.A & Pesquisa científica e tecnológica & $22.277,00$ & 2,04 \\
\hline FINATEC & Pesquisa científica e tecnológica & $21.190,30$ & 1,94 \\
\hline FUNDACAO UNIV. DE BRASILIA & Prod. de comissária e aeronáuticos & $16.166,90$ & 2,53 \\
\hline TAP & Atividade de Logística/transporte & $14.688,30$ & 1,48 \\
\hline FINK BRASÍLIA LDA & segurança e eletroeletrônicos & $13.786,00$ & 1,34 \\
\hline DIMENSAO COM. REP. LTDA & Prod. farmacêuticos & $13.093,20$ & 1,26 \\
\hline EQUIPLEX IND. FARMACEUTICA & Mala diplomática & $10.732,40$ & 1,20 \\
\hline EMBAIXADA AMERICANA (E.U.A) & Prod. Médico-hospitalares & $10.177,00$ & 0,98 \\
\hline CRUZ VERMELHA & Atividade de Logística/transporte & $9.864,90$ & 0,93 \\
\hline TRANSPORTES NOGUEIRA LIMA & & $\mathbf{8 8 3 . 7 0 2 , 0 0}$ & $\mathbf{8 0 , 8 7}$ \\
\hline Total 20 maiores & & $209.095,64$ & 19,13 \\
\hline Total Outros & & $\mathbf{1 . 0 9 2 . 7 9 7 , 6 4}$ & $\mathbf{1 0 0 , 0 0}$ \\
\hline Total Geral & &
\end{tabular}

Fonte: Adaptado do TECAplus. INFRAERO 2010.

O setor de importação do TECA no último ano ganhou impulso com a entrada no mercado das empresas TAP - Transportes Aéreos Portugueses e Delta Air Lines, dos cargueiros citados anteriormente, de investimentos em equipamentos e mão-de-obra e principalmente do aquecimento da economia do Distrito Federal e entorno, com destaque a elevada renda per capita da população e do crescimento

\footnotetext{
${ }^{1}$ CIF- cost, insurance and freight (custo, seguro e frete), significa que todos os custos de transporte e seguro estão incluídos até a alfândega do país de importação e correm por conta do vendedor, este termo é utilizado no transporte marítimo, devendo ser utilizado o termo CIP para transporte aéreo.
} 
do pólo de Anápolis-GO em relação a produtos farmacêuticos e de biotecnologia.

Tabela 9: Evolução da Carga Importada - TECA-BR com ATAERO'1

\begin{tabular}{|c|c|c|c|c|}
\hline & $\begin{array}{c}\text { TOTAL RECEITA } \\
2006 \text { (R\$) }\end{array}$ & $\begin{array}{c}\text { TOTAL RECEITA } \\
2007 \text { (R\$) }\end{array}$ & $\begin{array}{c}\text { TOTAL RECEITA } \\
2008 \text { (R\$) }\end{array}$ & $\begin{array}{l}\text { TOTAL RECEITA } \\
2009(\mathbf{R} \$)\end{array}$ \\
\hline BRASÍLIA & $6.524 .722,95$ & $7.495 .190,11$ & $5.451 .720,87$ & $5.310 .443,88$ \\
\hline EVOLUÇÃO & $4,03 \%$ & $14,87 \%$ & $-27,26 \%$ & $-2,59 \%$ \\
\hline BRASIL & 644.960 .716 & 697.347 .609 & 868.845 .605 & 716.341 .224 \\
\hline \multirow[t]{2}{*}{ EVOLUÇÃO } & $-23,40 \%$ & $8,12 \%$ & $24,59 \%$ & $-17,55 \%$ \\
\hline & TOTAL PESO (KG) & TOTAL PESO (KG) & TOTAL PESO (KG) & TOTAL PESO (KG) \\
\hline BRASÍLIA & 2.704 .075 & 2.060 .811 & 3.179 .917 & 2.673 .480 \\
\hline EVOLUÇÃO & $-8,36 \%$ & $-23,79 \%$ & $54,30 \%$ & $-15,93 \%$ \\
\hline BRASIL & $327.009 .094,00$ & $283.761 .504,00$ & $278.153 .083,00$ & $229.600 .586,00$ \\
\hline EVOLUÇÃO & $12,83 \%$ & $-13,23 \%$ & $-1,98 \%$ & $-17,46 \%$ \\
\hline
\end{tabular}

Fonte: Adaptado de Infranet; INFRAERO, 2010

Observando a tabela percebe-se que houve uma queda de arrecadação do SBBR no ano de 2008, não acompanhando o crescimento a nível Brasil. Isto é explicado pela arrecadação atípica em 2007 referentes a cargas do Ministério da Saúde (MS) de alto valor agregado, que por falha no processo de despacho aduaneiro pelo agente de carga não foi liberada dentro do prazo de isenção de 30 dias, gerando uma receita no valor de $\mathrm{R} \$ 1.779 .575,51$ (23,7\% do total) atingindo a liderança na arrecadação naquele ano. Em 2007, as receitas proveniente do MS não figuram nem mesmo entre as dez maiores e em 2008 ficou na sétima posição com $5,0 \%$ do total arrecadado. Podemos perceber este fenômeno, em que houve uma queda na receita de importação, mas um crescimento na tonelagem movimentada.

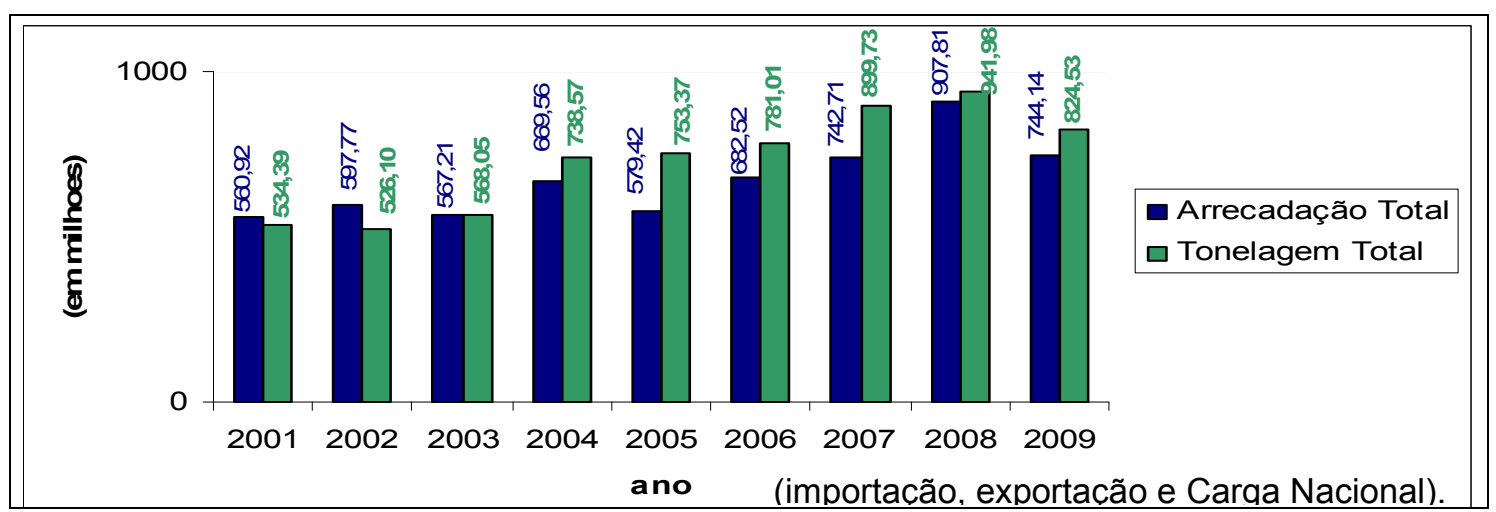

Figura 16: Evolução agrupada da carga no SBBR Fonte: Adaptado de SIGCA. INFRAERO, 2010.

\footnotetext{
${ }^{1}$ ATAERO: Adicional de Tarifa Aeroportuária criado pela lei $7.920 / 89$, no valor de $50 \%$ (cinqüenta por cento) sobre as tarifas aeroportuárias referidas no art. $3^{\circ}$. da Lei $n^{\circ} 6.009 / 7$, para aplicação em melhoramentos, reaparelhamento, reforma, expansão e depreciação de instalações aeroportuárias e da rede, assim distribuídas: $38,5 \%$ ao fundo aeronáutico (SEFA), 20\% ao PROFAA (SEFA) e 41,5\% à INFRAERO.
} 
Ainda em relação à importação nos aeroportos brasileiros temos uma situação crítica em relação a cargas em processo de perdimento, ou seja, aquelas abandonadas nos recintos alfandegados, onde o importador desiste de efetuar o despacho aduaneiro dentro do prazo legal por ação ou omissão voluntária ou involuntária. A prestação de serviços relativa à guarda, manuseio, movimentação e controle das cargas sob pena de perdimento é confiada ao fiel depositário, por intermédio de contrato amparado pelo Fundo Especial de Desenvolvimento e Aperfeiçoamento das Atividades de Fiscalização - FUNDAF, celebrado entre a autoridade aduaneira e o administrador aeroportuário, cujos pressupostos legais estão previstos na Lei $n^{\circ}$ 8.666/93. Em muitos aeroportos essas cargas constituem um sério gargalo, ocupando uma área de até $86 \%$ em relação à cargas ativas.

Tabela 10:Cargas em perdimento. Dez maiores em no processos em 2009

\begin{tabular}{|c|c|c|c|c|c|c|}
\hline \multirow[t]{2}{*}{ TECA } & \multicolumn{2}{|c|}{$\begin{array}{c}\text { Capacidade Operacional } \\
.000 \text { t/ano }\end{array}$} & \multirow{2}{*}{$\begin{array}{c}\% \text { Perdimento/ } \\
\text { cargas ativas }\end{array}$} & \multirow{2}{*}{$\begin{array}{c}\text { Área } \\
\text { Ocupada }\end{array}$} & \multirow[t]{2}{*}{ PROCESSOS } & \multirow[t]{2}{*}{ Permanência média } \\
\hline & Import. & Export. & & & & \\
\hline SBGR & 154 & 143 & 41,50 & 15.00 & 28.604 & 2 anos \\
\hline SBKP & 106 & 97 & 86,04 & 27,47 & 25.000 & 3 a 4 anos \\
\hline SBGL & 99 & 81 & 55,00 & 35,00 & 801 & Sup. a 4 anos \\
\hline SBEG & 197 & 26 & 10,45 & 2,64 & 200 & Sup. a 4 anos \\
\hline SBCF & 43 & 4 & 6,00 & 4,00 & 139 & 5 anos \\
\hline SBSV & 10 & 6 & 33,70 & 16,00 & 136 & * \\
\hline SBRF & 7 & 5 & 12,00 & 1,00 & 125 & Sup. a 4 anos \\
\hline SBCT & 117 & 26 & 0,05 & 0,73 & 104 & 4 meses \\
\hline SBBR & 6 & 3 & 0,15 & 6,00 & 78 & 1 ano \\
\hline SBVT & 8 & 1 & 10,00 & 4,00 & 58 & * \\
\hline
\end{tabular}

* Não informado no estudo

Fonte: adaptado de ANAC; BNDES, 2009.

Percebemos pela tabela acima que as cargas em perdimento não constituem um gargalo em Brasília, pois representam somente $0,15 \%$ em relação as cargas ativas, sendo subutilizada a área destinada a sua guarda no TECA-BR $\left(400 \mathrm{~m}^{2}\right)$.

No que tange exportações aéreas no Distrito Federal temos uma arrecadação ínfima $(0,18 \%$ do total em 2009$)$ quando comparada às importações - 83,62\%, e com a carga doméstica 16,20\%; justamente porque a maioria dos produtos exportados no DF não são de alto valor agregado e não tem urgência para chegar ao destino. Outro fator é a concorrência do Porto Seco do Distrito Federal e de 
Anápolis-GO, que oferece tarifas mais baixas e períodos de carência maiores, não sendo necessário ao exportador utilizar o recinto do aeroporto (zona primária); mesmo quando a exportação é por via aérea nos aeroportos do sudeste, é mais vantajoso para o exportador o transporte rodoviário pela modalidade de trânsito aduaneiro (TC-4) até o aeroporto de embarque, devido ao alto custo do transporte de carga aéreo e maior celeridade no desembaraço no Porto Seco.

Tabela 11: Evolução da Carga Exportada - TECA-BR - com ATAERO

\begin{tabular}{|c|c|c|c|c|}
\hline & $\begin{array}{c}\text { TOTAL RECEITA } \\
2006 \\
\text { (R\$) }\end{array}$ & $\begin{array}{c}\text { TOTAL RECEITA } \\
2007 \\
\text { (R\$) }\end{array}$ & $\begin{array}{c}\text { TOTAL RECEITA } \\
2008 \\
\text { (R\$) }\end{array}$ & $\begin{array}{c}\text { TOTAL RECEITA } \\
2009 \\
\text { (R\$) }\end{array}$ \\
\hline BRASÍLIA & $36.335,60$ & $21.859,68$ & $11.297,41$ & $11.445,40$ \\
\hline EVOLUÇÃO & $29,37 \%$ & $-39,84 \%$ & $-48,32 \%$ & $1,31 \%$ \\
\hline BRASIL & 19.967 .596 & 19.145 .877 & 18.242 .789 & 15.925 .716 \\
\hline \multirow[t]{2}{*}{ EVOLUÇÃO } & $-23,40 \%$ & $-4,12 \%$ & $-4,72 \%$ & $-12,70 \%$ \\
\hline & $\begin{array}{l}\text { TOTAL PESO } \\
\text { (KG) } \\
2006\end{array}$ & $\begin{array}{l}\text { TOTAL PESO } \\
\text { (KG) } \\
\mathbf{2 0 0 7}\end{array}$ & $\begin{array}{l}\text { TOTAL PESO } \\
\text { (KG) } \\
\mathbf{2 0 0 8}\end{array}$ & $\begin{array}{l}\text { TOTAL PESO } \\
\text { (KG) } \\
\mathbf{2 0 0 9}\end{array}$ \\
\hline BRASÍLIA & 353.415 & 232.019 & 135.309 & 134.589 \\
\hline EVOLUÇÃO & $15,20 \%$ & $-34,35 \%$ & $-41,68 \%$ & $-0,53 \%$ \\
\hline BRASIL & $259.176 .901,00$ & $283.761 .504,00$ & $278.153 .083,00$ & $229.600 .586,00$ \\
\hline EVOLUÇÃO & $-7,17 \%$ & $9,49 \%$ & $-1,98 \%$ & $-17,46 \%$ \\
\hline
\end{tabular}

Fonte: Adaptado de Infranet; INFRAERO, 2010.

Em nível nacional as exportações obtiveram queda devido a desvalorização cambial (Anexo C). A taxa média do dólar de 2008 ficou em $R$ \$ 1,838 contra $R \$$ 1,948 em 2007, que apresentou desvalorização média de 10,6\% em relação a 2006. No caso de Brasília as exportações são tipicamente de bagagens, animais domésticos e mudanças de diplomatas. Em 2007, houve saída de um cliente expressivo, a indústria Rossi, que exportava peças e motores, o que levou a uma queda significativa a partir daquele ano. Em 2009, a arrecadação no primeiro trimestre caiu principalmente devido aos reflexos da crise de 2008. Com o aumento do parque industrial do DF é possível uma melhoria deste quadro. Programas como o Pró-DF I e II, instalação de indústrias de ponta, implementação de plataforma aeroportuária industrial, podem estimular as exportações pelo modal aéreo, como também a capacitação dos empreendedores do meio rural para explorar a exportação de frutas e flores e aproveitar a capacidade ociosa dos porões das aeronaves que operam vôos internacionais, principalmente Delta Air Lines (3,6 toneladas), TAP (15 toneladas) e cargueiros (acima de 60 toneladas), que retornam 
a origem com os porões vazios na maioria dos vôos, sendo um dos fatores que mais encarecem o transporte aéreo de carga. Esse mercado vem sendo bem explorado no aeroporto de Petrolina na Bahia. As exportações no DF são, na maior parte, de produtos transportados tipicamente por modais não-aéreos.

Tabela 12: Exportações no Distrito Federal: 2006 à 2009

\begin{tabular}{c|c|c|c|c|c|c|c}
\hline ANO & Básicos & $\begin{array}{c}\text { Industrializados } \\
(\mathbf{A}+\mathbf{B})\end{array}$ & $\begin{array}{c}\text { Semi } \\
\text { manufat.(A) }\end{array}$ & $\begin{array}{c}\text { Manufat. } \\
(\mathbf{B})\end{array}$ & $\begin{array}{c}\text { Operações } \\
\text { Especiais }\end{array}$ & T O T A L & Var. (\%) \\
\hline $\mathbf{2 0 0 6}$ & 63.016 & 2.238 & 8 & 2.230 & 913 & $\mathbf{6 6 . 1 6 8}$ & $10,04 \%$ \\
\hline $\mathbf{2 0 0 7}$ & 73.598 & 2.477 & --- & 2.477 & 5.453 & $\mathbf{8 1 . 5 2 8}$ & $23,21 \%$ \\
\hline $\mathbf{2 0 0 8}$ & 140.462 & 2.065 & --- & 2.065 & 22.609 & $\mathbf{1 6 5 . 1 3 6}$ & $102,55 \%$ \\
\hline $\mathbf{2 0 0 9}$ & 114.744 & 1.448 & 2 & 1.446 & 13.888 & $\mathbf{1 3 0 . 0 8 0}$ & $-\mathbf{2 1 , 2 3 \%}$ \\
\hline
\end{tabular}

OBS: Totais por Fator Agregado US\$1.000 - VALOR FOB ${ }^{1}$.

Fonte: Adaptado de MDIC, 2010.

Os dez maiores exportadores no DF em ordem de importância são: Sadia S.A.; Multigrain S.A.; Maeda S.A. Agroindustrial; ADM do Brasília LTDA; AWB Brasília LTDA; Comissaria Aérea Brasília LTDA; Indústrias Rossi Eletromecânica LTDA; Grupo Pão de Açucar; Topocart Engenharia. Os principais destinos em ordem de importância são: Venezuela, Kuwait, Portugal, Japão, Emirados Árabes Unidos, Arábia Saudita, Hong Kong, China, Países Baixos(Holanda) e lêmen. Dos produtos exportados $98,75 \%$ são de carnes e miudezas de galos/galinhas (72,45\%); grãos de soja - mesmo triturados (15,66\%), Consumo de bordo para aeronaves: combustíveis, lubrificantes, comissaria (10,64\%). (MDIC 2010).

No que diz respeito a Carga Nacional ou Carga Doméstica, é uma atividade recente no aeroporto de Brasília. Somente a partir de 2004 começou a exploração deste segmento, onde a operacionalização da área era de forma empírica e manual, pois não havia um sistema de informações e armazenagem de cargas como o TECAPLUS do setor de importação. No TECA-BR a área destinada à armazenagem é divida com a empresa Varig-Log, que subutiliza o espaço. A INFRAERO pediu a devolução da área, mas por questões judiciais a empresa continua com a posse. (Informação verbal².

\footnotetext{
${ }^{1}$ FOB: (free on board ou livre a bordo) preço de exportação, ou seja, incluem as despesas que não integram a composição do preço interno tais como embalagem para exportação, transporte até o local de embarque, desembaraço da carta etc. No transporte aéreo o termo correto é FCA.

${ }^{2}$ Informação obtida junto ao Coordenador da Carga Nacional em 2009.
} 
$\mathrm{Na}$ rede INFRAERO esta é uma atividade ainda pouco explorada, estando presente em apenas 13 dos 67 aeroportos, com destaque para o aeroporto de Manaus-AM com arrecadação de R\$ 6.866.195 (48,90\% do total), Guarulhos-SP com R\$ 3.070.873 (21,51\%), Recife-PE com R\$1.297.967 (9,09\%) e Brasília-DF com R\$ 1.028.645 (7,20\%) do total. Os demais aeroportos (SBBE, SBJP, SBKP, SBFZ, SBPV, SBPA, SBSV, SBCT e SBNT) somados correspondem a $14,10 \%$ do total. (INFRAERO, 2010).

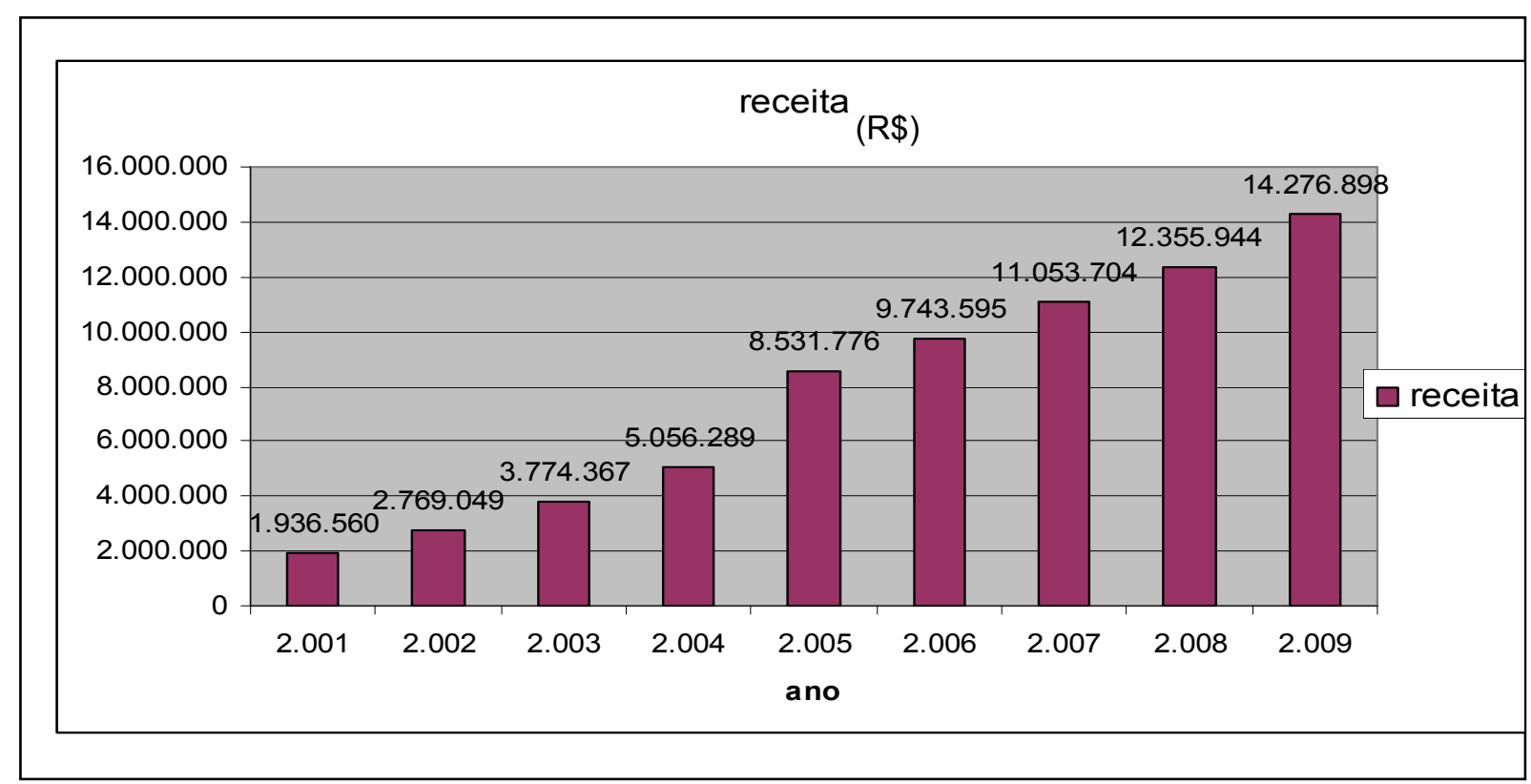

Figura 17: Evolução das receitas da carga doméstica na rede INFRAERO Fonte: Adaptado de SIGCA; INFRAERO, 2010.

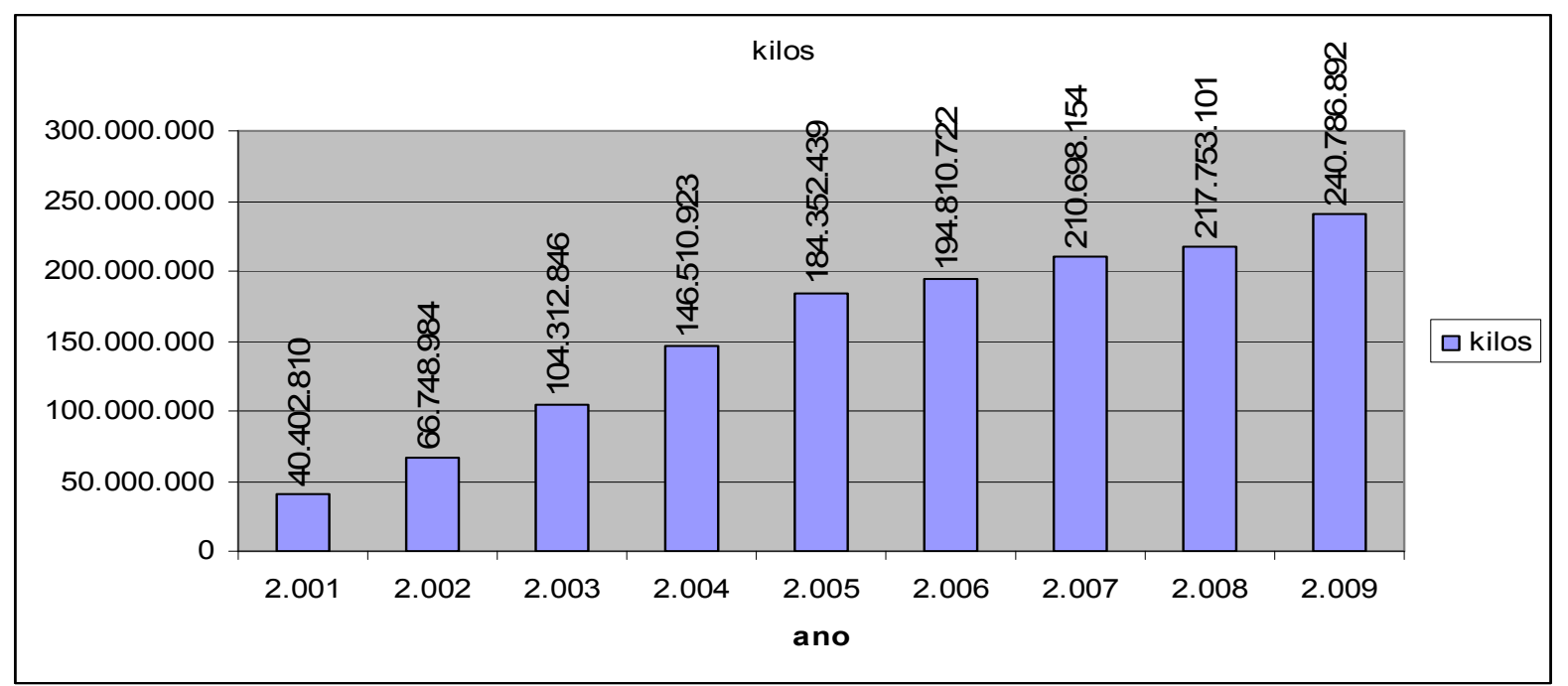

Figura 18: Evolução por peso da Carga Doméstica na rede INFRAERO Fonte: Adaptado de SIGCA; INFRAERO, 2010

Como se pode observar, o setor de Carga Nacional na INFRAERO é uma atividade promissora e que vem apresentando franco crescimento ao longo da 
década.

Tabela 13: Evolução da Carga Doméstica - TECA-BR - com ATAERO

\begin{tabular}{|c|c|c|c|c|}
\hline & $\begin{array}{c}\text { TOTAL RECEITA } \\
2006 \\
\text { (R\$) }\end{array}$ & $\begin{array}{c}\text { TOTAL RECEITA } \\
2007 \\
(\mathbf{R} \$)\end{array}$ & $\begin{array}{c}\text { TOTAL RECEITA } \\
2008 \\
\text { (R\$) }\end{array}$ & $\begin{array}{c}\text { TOTAL RECEITA } \\
\mathbf{2 0 0 9} \\
\text { (R\$) }\end{array}$ \\
\hline BRASÍLIA & 33.388 & 68.009 & 905.217 & 1.028 .646 \\
\hline EVOLUÇÃO & $-23,40 \%$ & $103,69 \%$ & $1231,03 \%$ & $13,64 \%$ \\
\hline BRASIL & 9.743 .595 & 11.053 .704 & 12.355 .944 & 14.276 .898 \\
\hline \multirow[t]{2}{*}{ EVOLUÇÃO } & $-23,40 \%$ & $13,45 \%$ & $11,78 \%$ & $15,55 \%$ \\
\hline & $\begin{array}{l}\text { TOTAL PESO } \\
\text { (KG) } \\
2006 \\
\end{array}$ & $\begin{array}{c}\text { TOTAL PESO } \\
\text { (KG) } \\
2007 \\
\end{array}$ & $\begin{array}{c}\text { TOTAL PESO } \\
(\mathrm{KG}) \\
2008 \\
\end{array}$ & $\begin{array}{c}\text { TOTAL PESO } \\
\text { (KG) } \\
2009 \\
\end{array}$ \\
\hline BRASÍLIA & 201.472 & 1.026 .405 & 5.702 .960 & 6.995 .740 \\
\hline EVOLUÇÃO & $22,57 \%$ & $409,45 \%$ & $455,62 \%$ & $22,67 \%$ \\
\hline BRASIL & $194.810 .722,00$ & $210.698 .154,00$ & $217.753 .101,00$ & $240.786 .892,20$ \\
\hline EVOLUÇÃO & $105,67 \%$ & $8,16 \%$ & $3,35 \%$ & $10,58 \%$ \\
\hline
\end{tabular}

Fonte: Adaptado de Infranet; INFRAERO, 2010.

O setor de Carga Nacional no AlB-PJK é uma atividade no momento improdutiva devido aos altos custos de manutenção da atividade, pois a INFRAERO oferta infraestrutura de armazéns, equipamentos, mão-de-obra de capatazia (operadores de empilhadeiras e separadores de carga), vigilância armada, limpeza, monitoramento eletrônico e demais despesas físicas de energia, salários de orgânicos, etc., a um custo de armazenagem de apenas $\mathrm{R} \$ 0,04$ por kilo. $O$ método de cobrança da carga internacional é pelo valor CIF, o que eleva substancialmente a arrecadação. Há discrepância na política de desconto, onde o pagamento à vista é mais oneroso ao cliente do que o pagamento à prazo.

No que diz respeito a viabilidade econômica do TECA-BR: internacional e nacional, temos o seguinte quadro:

Tabela 14: Viabilidade econômica do TECA-BR.

\begin{tabular}{c|c|c|c|c}
\hline & 2006 & 2007 & 2008 & 2009 \\
\hline RECEITA & $6.615 .996,65$ & $7.617 .857,61$ & $6.440 .643,97$ & $6.476 .730,90$ \\
\hline CUSTO OPER. & $1.400 .810,43$ & $1.385 .166,22$ & $1.756 .915,17$ & $2.761 .404,32$ \\
\hline LUCRATIVIDADE & $78,83 \%$ & $81,82 \%$ & $72,72 \%$ & $57,36 \%$ \\
\hline
\end{tabular}

Fonte: Adaptado de Infranet; INFRAERO, 2010.

A avaliação da viabilidade econômica engloba as receitas, despesas e custos da Carga Nacional e Internacional. Existe a necessidade de maior precisão nestes indicadores, pois são agrupados os custos e receitas das duas áreas, não se 
obtendo uma avaliação precisa da produtividade da Carga Nacional, onde as receitas são bem inferiores ao setor de Carga Internacional e cujos custos superam a arrecadação da área. A lucratividade foi medida pela diferença entre receita e custo e a proporção do resultado em relação à receita.

\subsection{Resultados da Pesquisa Descritiva Qualitativa}

A seguir são detalhadas as opiniões preponderantes dos gestores da atividade de logística de carga no Aeroporto Internacional de Brasília, com as principais observações e sugestões dos respondentes. No Apêndice A constam o questionário classificado por variáveis e no Apêndice $C$ a relação dos respondentes:

A maioria absoluta dos gestores tem uma opinião positiva e favorável em relação à atividade de logística no aeroporto, com expectativas otimistas para o setor e para o futuro complexo logístico do aeroporto de Brasília.

Tabela 15: Respostas dos gestores do TECA-BR:

\begin{tabular}{|c|c|}
\hline PERGUNTAS & Respostas de maior relevância \\
\hline $\begin{array}{l}\text { Como avalia a logística de carga } \\
\text { internacional no AIB-PJK? Como } \\
\text { está evoluindo nos últimos anos } \\
\text { em termos financeiros e de } \\
\text { infraestrutura? Existem pontos a } \\
\text { serem melhorados? }\end{array}$ & $\begin{array}{l}\text { - Importação: é uma atividade lucrativa e que vem crescendo nos } \\
\text { últimos anos. É modelo de gestão na rede INFRAERO e foram feitos } \\
\text { investimentos que suprem até o momento a atividade. } \\
\text { - Exportação: é uma atividade com arrecadação inexpressiva devido } \\
\text { à falta de um parque tecnológico no Distrito Federal. } \\
\text { - A infraestrutura: é adequada para a demanda atual, com exceção } \\
\text { de cargas que precisam resfriamento. Houve melhora no efetivo } \\
\text { orgânico no presente ano, o que elevou o nível de atendimento ao } \\
\text { cliente. Principais pontos a serem melhorados são otimização de pé } \\
\text { direito, modernização na coleta de informações da carga, } \\
\text { disponibilização de espaço para atendimento das exigências dos } \\
\text { órgãos anuentes em } 100 \% \text {, câmaras frigoríficas etc. }\end{array}$ \\
\hline $\begin{array}{l}\text { Como avalia a logística de carga } \\
\text { nacional no AIB-PJK? Como está } \\
\text { evoluindo nos últimos anos em } \\
\text { termos financeiros e de } \\
\text { infraestrutura? Existem pontos a } \\
\text { serem melhorados? }\end{array}$ & $\begin{array}{l}\text { É uma atividade recente em Brasília e que possui grande potencial de } \\
\text { mercado. A partir de } 2008 \text { começou a oferta de aluguéis de salas e } \\
\text { conseqüentemente estimulou a atividade de cross-docking, o que elevou } \\
\text { a arrecadação exorbitantemente. Houve também um esforço gerencial } \\
\text { para atrair cargueiros para utilização do TECA. A infraestrutura de } \\
\text { armazém destinado a carga doméstica é insuficiente e precisa ser } \\
\text { reavaliado a política de tarifas, pois apesar da grande quantidade de }\end{array}$ \\
\hline
\end{tabular}




\begin{tabular}{|c|c|}
\hline & $\begin{array}{l}\text { carga movimentada a arrecadação é baixa frente aos custos No que diz } \\
\text { respeito a fiscalização da carga dos órgãos anuentes deixa-se muito a } \\
\text { desejar. Cargas que não são courier e operadas pelos Correios } \\
\text { poderiam ser tarifadas pela utilização da estrutura aeroportuária, o que } \\
\text { já acontece em alguns aeroportos. }\end{array}$ \\
\hline $\begin{array}{l}\text { Existe potencial de mercado de } \\
\text { cargas a ser explorado para o } \\
\text { aeroporto na atual conjuntura? }\end{array}$ & $\begin{array}{l}\text { Sim. O TECA Internacional possui capacidade ociosa de armazenagem, } \\
\text { sendo necessário um trabalho mais efetivo de mercado na busca de } \\
\text { clientes e flexibilização tarifária para concorrer mais eficazmente no } \\
\text { mercado. É fundamental maior atuação das políticas públicas no setor. }\end{array}$ \\
\hline $\begin{array}{l}\text { Na sua opinião a infraestrutura } \\
\text { tecnológica do TECA-BR é } \\
\text { moderna? Quais investimentos } \\
\text { seriam necessários para torná-la } \\
\text { mais competitiva? }\end{array}$ & $\begin{array}{l}\text { Não, é uma infraestrutura tecnológica básica, mas que atende } \\
\text { plenamente a demanda atual. Alguns investimentos como } \\
\text { transelevadores não são justificáveis para a demanda atual, mas outros } \\
\text { são plenamente justificáveis como pranchas e esteiras automatizadas, } \\
\text { leitores ópticos, palmtops, sistema COAPI - transmissão de informações } \\
\text { em tempo real dos dados da carga (peso, avaria etc) ao sistemas de } \\
\text { armazenagem, entre outros menos onerosos. Estão sendo avaliados até } \\
\text { mesmo a integração a sistemas de identificação por rádio freqüência } \\
\text { (RFID). }\end{array}$ \\
\hline $\begin{array}{l}\text { Em relação ao sistema de } \\
\text { informação gerencial TECAPLUS, } \\
\text { qual sua opinião em relação à } \\
\text { adequação operacional do sistema } \\
\text { e quais melhorias poderiam ser } \\
\text { desenvolvidas, caso necessárias? }\end{array}$ & $\begin{array}{l}\text { É um sistema antigo, criado há } 15 \text { anos, mas que supre a necessidade } \\
\text { operacional da área e o controle eficiente da carga. Possui inúmeras } \\
\text { interfaces, mas que precisam ser mais adequadas à dinamicidade da } \\
\text { atividade. Existem pontos a serem melhorados no que diz respeito a } \\
\text { busca de informações, relatórios e atendimento da realidade local, } \\
\text { estudos de tempos e movimentos de carga etc. O sistema utilizado na } \\
\text { Carga Nacional não atende a realidade, pois é uma adaptação do } \\
\text { sistema utilizado na internacional e carece de operacionalidade } \\
\text { funcional eficaz. O ideal seria a unificação do sistema dos setores } \\
\text { internacionais e nacionais, e a integração das informações a nível Brasil. }\end{array}$ \\
\hline $\begin{array}{l}\text { No que diz respeito aos relatórios } \\
\text { gerenciais da logística de carga, } \\
\text { estes retratam com eficiência a } \\
\text { atividade, abordando todos os } \\
\text { elementos necessários para } \\
\text { análises financeiras, operacionais e } \\
\text { de mercado? }\end{array}$ & $\begin{array}{l}\text { Sim, o sistema TECAPLUS fornece todas as informações necessárias, } \\
\text { mas possui limitações no que diz respeito a consolidação e visualização } \\
\text { de dados consolidados em forma de gráficos e algumas informações } \\
\text { específicas para a realidade de Brasília e relatórios gerenciais. Por ser } \\
\text { um sistema padrão em toda a rede, as adequações e modificações são } \\
\text { vagarosas, pois ao mudar uma variável, esta impactará todos os outros } \\
\text { TECAS. }\end{array}$ \\
\hline $\begin{array}{l}\text { Quais são os pontos considerados } \\
\text { críticos na atividade de recepção, } \\
\text { armazenagem e despacho de } \\
\text { carga no AIB-PJK, e como podem } \\
\text { ser melhorados, caso existirem? }\end{array}$ & $\begin{array}{l}\text { Este processo é modelo em Brasília, pois por parte da INFRAERO a } \\
\text { carga é liberada dentro da meta estabelecida de } 12 \text { horas, e está bem } \\
\text { conceituada nos resultados de pesquisas atuais. Os maiores atrasos na } \\
\text { entrega da carga ao cliente são de responsabilidade, na quase } \\
\text { totalidade das vezes, dos despachantes aduaneiros. No TECA-BR só } \\
\text { existe uma empresa que fornece esse serviço. Poderia haver maior } \\
\text { investimento da INFRAERO em capacitação de pessoal, principalmente } \\
\text { do quadro terceirizado. Em situações esporádicas de chegada } \\
\text { simultânea de grandes volumes de cargas pelo modal aéreo e }\end{array}$ \\
\hline
\end{tabular}




\begin{tabular}{|c|c|}
\hline & $\begin{array}{l}\text { rodoviário, o quadro de pessoal se torna insuficiente para atender com } \\
\text { celeridade a despaletização e armazenagem da carga. }\end{array}$ \\
\hline $\begin{array}{l}\text { Como está fluindo as informações } \\
\text { entre os órgãos anuentes, } \\
\text { INFRAERO e demais stakeholders } \\
\text { (despachantes, agentes de carga e } \\
\text { clientes)? Está existindo a } \\
\text { celeridade dos processos e } \\
\text { produtividade dos armazéns? } \\
\text { Como é a relação entre estes } \\
\text { agentes. }\end{array}$ & $\begin{array}{l}\text { É necessário uma postura mais ágil dos órgãos anuentes que atuam no } \\
\text { terminal aeroportuário no que diz respeito a celeridade dos processos, } \\
\text { de maneira a acompanhar a eficiência da própria INFRAERO no } \\
\text { processo. A relação institucional entre a INFRAERO e estes atores é a } \\
\text { melhor possível e é feito um acompanhamento pessoal dos clientes pela } \\
\text { Coordenação de Atendimento ao Cliente. Os agentes de carga são na } \\
\text { quase totalidade das vezes os responsáveis pelos eventuais atrasos } \\
\text { ocorridos no setor. }\end{array}$ \\
\hline $\begin{array}{l}\text { Quais são as suas expectativas em } \\
\text { relação à construção do novo } \\
\text { Terminal de Passageiros - TPS do } \\
\text { AIB-PJK e principalmente do novo } \\
\text { Terminal de Cargas? Em sua } \\
\text { opinião é necessário aumentar a } \\
\text { capacidade do Terminal de Cargas } \\
\text { do Aeroporto de Brasília? }\end{array}$ & $\begin{array}{l}\text { É extremamente necessária a ampliação do TPS devido ao crescimento } \\
\text { cada vez maior no fluxo de paxs anualmente. Em relação ao Terminal } \\
\text { de Carga é extremamente necessário, pois o atual existe a } 35 \text { anos, e } \\
\text { se faz necessário modernizar, de forma a aumentar a demanda, rota de } \\
\text { cargueiros, tendo o DF grande potencial. Dentro da nova planta há a } \\
\text { possibilidade de investimento no aeroporto industrial e interligação } \\
\text { intermodal do aeroporto. O atual está aquém do padrão dos melhores } \\
\text { aeroportos internacionais. }\end{array}$ \\
\hline $\begin{array}{l}\text { Com os planos de investimento na } \\
\text { infraestrutura aeroportuária } \\
\text { brasileira pelo Programa de } \\
\text { Aceleração do Crescimento - PAC, } \\
\text { para os próximos anos, e os mega- } \\
\text { eventos como a Copa do Mundo e } \\
\text { Olimpíadas, que implicação têm } \\
\text { esses investimentos neste } \\
\text { aeroporto? Seria justificável a } \\
\text { ampliação do aeroporto? }\end{array}$ & $\begin{array}{l}\text { A INFRAERO é auto-suficiente em termos de rentabilidade e } \\
\text { investimentos. A atuação do PAC é bem vista, não só atuando no } \\
\text { sistema aeroportuário, mas nos outros modais, extremamente } \\
\text { importante para a multimodalidade. O aeroporto de Brasília tem posição } \\
\text { de destaque a nível Brasil como hub de passageiros e por ser localizado } \\
\text { estrategicamente no Centro-Oeste do país possui grande potencial } \\
\text { como hub de carga. }\end{array}$ \\
\hline $\begin{array}{l}\text { Como avalia a concorrência } \\
\text { existente, no âmbito do sítio } \\
\text { aeroportuário, no que diz respeito a } \\
\text { armazenagem de cargas } \\
\text { domésticas e internacionais. } \\
\text { Existe influência da iniciativa } \\
\text { privada no que diz respeito à } \\
\text { administração aeroportuária? }\end{array}$ & $\begin{array}{l}\text { Concorrência e ameaças existem. A concorrência em relação aos } \\
\text { Portos Secos no DF não é relevante devido a obrigatoriedade da carga } \\
\text { importada em passar pelo TECA-BR, sendo que apenas uma parcela } \\
\text { pequena }(4,98 \%) \text { é removida a zona secundária. A INFRAER tem } \\
\text { vantagens em quesitos como segurança, administração do complexo } \\
\text { aeroportuário, eficiência operacional, atendimento ao cliente, precisando } \\
\text { continuar os investimentos no setor. No que diz respeito à exportação se } \\
\text { faz necessário um trabalho mais efetivo de mercado de visitação a } \\
\text { clientes e demonstração de vantagens em se utilizar o TECA. É } \\
\text { fundamental a captação de novos clientes por meio de visitas e } \\
\text { programas de flexibilização tarifária; fidelização dos clientes atuais e de } \\
\text { outros que migraram para o Porto Seco. } \\
\text { Um dos pontos principais que precisam ser atacados para se ter } \\
\text { competitividade é a celeridade no processo de liberação da carga, que }\end{array}$ \\
\hline
\end{tabular}




\begin{tabular}{|l|l|}
\hline & $\begin{array}{l}\text { deixa a desejar quando comparado aos Portos Secos. Em relação à } \\
\text { Carga Nacional há um problema de saturação do armazém da } \\
\text { INFRAERO. Com a construção do novo complexo logístico poderá ser } \\
\text { possível fazer um trabalho de mercado mais adequado para se captar } \\
\text { clientes que utilizam os terminais dos Correios e da Cias Aéreas. }\end{array}$ \\
\hline $\begin{array}{l}\text { Como avalia a privatização dos } \\
\text { aeroportos brasileiros? Quais? } \\
\text { seriam os impactos no âmbito } \\
\text { organizacional da INFRAERO? }\end{array}$ & $\begin{array}{l}\text { A privatização é algo que precisa ser melhor avaliada, pois a } \\
\text { administração aeroportuária envolve questões sociais, de segurança } \\
\text { nacional e de continuidade de investimentos em aeroportos não } \\
\text { rentáveis, mas que são fundamentais para o desenvolvimento social, } \\
\text { além da administração dos Grupamentos de Navegação Aérea e } \\
\text { Unidade Técnicas de Navegação, fundamentais para a segurança da } \\
\text { aviação civil e soberania nacional. Talvez, a abertura de capital seja } \\
\text { mais vantajosa e adequada para a empresa. }\end{array}$ \\
\hline
\end{tabular}

De acordo com as respostas apresentadas obtêm-se o seguinte quadro em relação às variáveis abordadas:

1. Variável I: Demanda da carga aeroportuária: Expectativa positiva para demanda da carga aeroportuária; avaliação satisfatória da evolução histórica da movimentação de carga e algum grau de insatisfação em relação a infraestrutura do TERMINAL.

2. Variável II: Inovação Setorial Aeroportuária: a estrutura na atualidade supre a demanda, mas deixa a desejar em instalações, equipamentos modernos, e sistemas de informação gerenciais.

3. Variável III: Manuseio, Guarda e desembaraço da Carga: Brasília é modelo entre os terminais da rede, mas carece de maior reforço no quadro funcional. Os agentes de carga e despachantes aduaneiros foram apontados como os maiores responsáveis pelos eventuais atrasos ocorridos na atividade.

4. Variável IV: Integração e perspectiva da logística Aeroportuária no DF : é fundamental a construção do futuro complexo logístico para o crescimento da atividade em Brasília e a expansão do Terminal de Passageiros que está saturado.

5. Variável V: Concorrentes das Atividades Aeroportuárias no DF: é necessário um trabalho de mercado mais eficaz para atrair clientes; melhorar a ocupação do atual terminal e aumentar a capacidade do terminal de forma a ganhar competitividade em relação aos concorrentes. 


\section{CONSIDERAÇÕES FINAIS}

A temática de transporte de carga aérea é de suma importância para o desenvolvimento econômico e social do país. A cada dia é maior o número de pessoas e empresas que utilizam o modal aéreo, constituindo importante fonte de geração de riquezas e na estratégia empresarial que envolve a logística de produtos de alto valor agregado e daqueles que utilizam as zonas primárias dos armazéns da INFRAERO no comércio exterior e terminais de carga doméstica - que na última década obtiveram crescimentos expressivos a nível nacional e regional.

Segundo Silva (1991) a infraestrutura aeroportuária deve levar em consideração as ações das diversas variáveis inerentes ao tráfego na rede: tipos de equipamentos, natureza dos intercâmbios como o turismo, os negócios, a aviação geral, o tráfego regular, a carga, o correio, etc. O tráfego local pode ser influenciado pelos problemas de regulamentação do serviço concedido ou autorizado, por fatores climáticos e ambientais, os quais, ao imporem algumas restrições operacionais, produzem algumas vezes efeitos sobre outras variáveis da rede. Os gestores devem considerar os setores utilizados pelas aeronaves e o utilizado por passageiros e cargas, incluindo o interior dos terminais. O planejamento geral da infraestrutura aeronáutica, incluídos os planos diretores aeroportuários, baseia-se no planejamento dos fluxos de tráfego de todos os modos de transporte associados às necessidades de desenvolvimento econômico e social da região e aos planos diretores de ordenamento territorial. O transporte aéreo faz parte integrante dos transportes considerados como um todo e diversos fatores externos à infraestrutura aeroportuária, como os financiamentos, a integração modal ou a política e os sistemas tarifários, devem ser levados em consideração.

Ao se avaliar a ampliação dos Terminais de Carga dos aeroportos brasileiros devem-se levar em consideração os fatores que justificam tais investimentos, como nível de rentabilidade, saturação de terminais e gargalos logísticos, relação entre os terminais de passageiros e TECAS, obsolescência dos TECAS, alternativas gerenciais para solução de gargalos pela redução de permanência da carga, celeridade nos processos de cargas em perdimento, automações de sistemas, utilização e redistribuição de áreas de setores adjacentes (importação, exportação, 
doméstico) subutilizados, melhor utilização da altura disponível no armazém e espaços entre prateleiras, otimização do tempo de turnaround e melhor distribuição do fluxo aéreo de aeronaves, entre outras alternativas menos onerosas.

Outros aspectos devem ser consideradas na avaliação dos Terminais de Carga Aeroportuários, tais como: variáveis de infraestrutura - posições no pátio de aeronaves, área do pátio de aeronaves, estrutura asfáltica com suporte para grandes cargueiros, área do terminal de cargas para exportação, importação e carga doméstica, área para guarda de cargas frias, comprimento básico da maior pista, área de estacionamento lado terra; variáveis de operação - automatização do armazenamento, freqüência de vôo das companhias, movimento anual de aeronaves, companhias aéreas presentes, agentes de carga presentes, docas no terminal de cargas; variáveis de localização - acessibilidade aos mercados (acesso viário), proximidade do centro de demanda gerador de potencial do mercado local (PIB e renda per capita), opções de intermodalidade; variáveis de Receita -: faturamento do aeroporto relativo a carga e variáveis de demanda - volume anual de carga. (OLIVEIRA, 2007)

Especificamente no Aeroporto de Brasília, o movimento operacional de pousos e decolagens e fluxo de passageiros já se encontram acima da capacidade de pátios, pistas e TPS, justificando plenamente investimentos de ampliação e melhora nestas estruturas operacionais, que não podem ser sanados com alternativas secundárias. No que diz respeito ao TECA-BR esta justificativa não é plausível, pois a área destinada à armazenagem tem uma taxa de ocupação entre $40 \%$ a $50 \%$ do disponível e cargas em processo de perdimento ocupam apenas $6 \%$ da área ocupada. Outros fatores precisam ser levados em conta neste caso, tais como:

$\left.1^{\circ}\right)$ O Terminal desempenha forte papel social junto aos órgãos públicos importadores, embaixadas e organizações de pesquisa e humanitárias e em períodos pontuais ocupam quase a totalidade da área disponível para armazenagem;

$\left.2^{\circ}\right)$ A estrutura do Terminal é obsoleta é não atende em $100 \%$ as exigências dos órgãos anuentes e agências reguladoras;

$3^{\circ}$ ) Analisando a tendência nos últimos anos em ocupação, por volumes e 
toneladas, a capacidade irá se exaurir em médio prazo. Vide figuras 16 e 18;

$\left.4^{\circ}\right)$ O Distrito Federal tem grande potencial como HUB de carga aérea na região Centro-oeste, além de potencial como pólo de indústrias limpas de alta tecnologia. O eixo Brasília-Anápolis-Goiânia possui grande potencial nos setores que envolvem biotecnologia e produtos farmacêuticos;

$5^{\circ}$ ) A localização do atual TECA impede as expansões em médio prazo do TPS, conforme se pode observar na Figura 11 e Apêndice D.

$\left.6^{\circ}\right)$ Existe enorme potencial no setor de carga doméstica, o qual se encontra com saturação em períodos específicos do ano;

$\left.7^{\circ}\right)$ A saturação de pátios e pistas interferem diretamente na operacionalidade da logística de carga.

Ao se analisar os aspectos financeiros da logística de carga aérea de Brasília, conforme abordado no capítulo anterior, e os investimentos previstos em torno de $\mathrm{R} \$ 133$ milhões, o retorno seria muito demorado e inviável em termos econômicos no curto e médio prazo. Mas pensando-se num horizonte de 20 a 30 anos, com as expectativas de crescimento da economia brasileira, do aumento da renda per capita brasiliense, da exposição do Brasil pelos mega-eventos futuros, exaustão em médio prazo do terminal, do potencial do aeroporto como hub de carga, é justificável tais empreendimentos. Neste horizonte o aeroporto atuará como cidade-aeroporto, atraindo empresas ligadas à aviação de todos os tipos para seus arredores. Estes incluem, entre outros, fabricantes e distribuidores; hotéis, entretenimento, varejo, convenções, exposições comerciais, complexos, edifícios de escritórios, agência de viagens entre outras inúmeras facilidades. O novo Complexo logístico atuará como plataforma logística, acolhendo e conectando empreendimentos e infraestruturas de diversos modais de transporte (ferroviário, dutoviário e rodoviário), prestadores de serviços avançados em logística e comércio exterior, aumento do leque de concessionárias de transporte e agentes aduaneiros, melhorando a competitividade. Possibilidade de atuação como aeroporto indústria, projeto piloto da INFRAERO em alguns Estados Brasileiros que incluem atividades de armazenagem, exposição, demonstração, teste de funcionamento, industrialização e manutenção ou reparo na área industrial, permitindo a armazenagem de mercadorias com suspensão dos pagamentos dos impostos e com 
direito à utilização dos benefícios fiscais relativos à exportação, antes do efetivo embarque para o exterior, o que irá alavancar as exportações via aeroporto, principalmente em setores como aeronáutica, eletroeletrônica, informática, telecomunicações, quick assembling ou montagem rápida, biotecnologia, hortifrutigranjeiros, entre outros.

Em relação a carga doméstica o TECA-BR poderá alavancar expressivamente a atividade. A falta de estrutura atual impossibilita a expansão das receitas. Cargas que poderiam estar sob a guarda da INFRAERO, ou seja, aquelas que não são mala postal, são operacionalizadas pelo correio, e outras poderiam ser taxadas pela utilização da infraestrutura de pátios e pistas, o que estimularia a utilização dos armazéns da INFRAERO. Outra possibilidade é atrair cargas que são armazenadas pelas próprias companhias aéreas pelas vantagens em enxugar custos. A atividade de armazenagem envolve altos custos de manutenção de armazéns, equipamentos, mão-de-obra de capatazia (operadores de empilhadeiras e separadores de carga), vigilância armada, limpeza, monitoramento eletrônico e demais despesas físicas de energia, salários de orgânicos, entre outros.

Em suma, a realização destes projetos poderá elevar o AIB-PJK ao patamar dos melhores aeroportos do mundo, no que diz respeito a qualidade no atendimento e conforto de passageiros e da comunidade aeroportuária como um todo, e na cadeia logística mundial, sendo plenamente justificáveis tais investimentos do ponto de vista mercadológico e estratégico.

\subsection{Recomendações para Futuras Pesquisas}

As bibliografias e estudos técnicos que envolvem o transporte aéreo de cargas no Brasil são bastante escassos. Muitos dos dados disponíveis na rede mundial de computadores pelos órgãos governamentais brasileiros são divergentes, desatualizados e desintegrados, o que dificulta a pesquisa acadêmica e científica. Muitas das informações disponíveis com maior riqueza e assertividade são provenientes de entidades e empresas internacionais da aviação civil e restringemse na maior parte aos mercados norte-americano, europeu e asiático. 
No que tange ao transporte de carga aérea no Brasil, existe demanda reprimida, carência de estudos de mercado e de gestão mais qualificada dos atores envolvidos. A ênfase das políticas governamentais é voltada o transporte rodoviário, ferroviário e marítimo, e no caso do transporte aéreo a ênfase é em terminais de passageiros e infraestrutura operacional de pátios e pistas.

Especificamente, para o Aeroporto de Brasília, existem muitas frentes de estudo que podem ser focadas, tais como: fluxo de informações operacionais e gerenciais de logística; melhora nos processos de liberação de carga; adequação e modernização da infraestrutura tecnológica e física relacionada à logística; aspectos mercadológicos da cadeia logística - tanto do comércio exterior quanto nacional; melhor capacitação dos funcionários envolvidos na atividade; intermodalidade do transporte local e regional; acesso viário ao aeroporto, avaliação dos impactos da administração privada em detrimento da pública em aeroportos, ou da abertura de capital; inserção de Brasília no mercado mundial de cargas, aspectos ambientais e de destinação de resíduos, entre outros. 


\section{REFERÊNCIAS}

ACl, 2010. In: World Airport Traffic Report for 2009. Disponível em: < http://www.aci.aero/cda/aci_common/display/main/aci_content07_c.jsp?zn=aci\&cp=1 -5-54_666_2_> Acesso em: 31 ago. 2010.

ACINH (Nova Hamburgo-RS). Cotação do dólar entre os anos 2005 à 2009. Disponível em: < http://www.acinh.com.br/cotacao.asp. Acesso em: 25 jul. 2010.

BALLOU, Ronald H. Gerenciamento da cadeia de suprimentos/logística empresarial; tradução Raul Rubenich. 5. ed. Porto Alegre: Bookmam, 2006.

BNDES (Rio de Janeiro, RJ). Estudo do Setor de Transporte Aéreo no Brasil. Rio de Janeiro, 2010. p. 122. Disponível em : <http://www.bndes.gov.br/SiteBNDES/ export/sites/default/bndes_pt/Galerias/Arquivos/empresa/pesquisa/chamada3/20100 125-Infraestrutura.pdf>. Acesso em: 11 Ago. 2010.

BONIN, Robson. Brasil: aeroportos para Copa de 2014 estão no limite da capacidade, diz IPEA. Agência DIAP, Brasília-DF, mai. 2010. Disponível em: < http://www.diap.org.br/index.php/agencia-diap/13211-brasil-aeroportos-para-copade-2014-estao-no-limite-da-capacidade-diz-ipea>. Acesso em: 30 jul. 2010.

BOWERSOX, Donald J; CLOSS, David J; COOPER, M. Bixby. Gestão de cadeias de suprimentos. Porto Alegre: Bookmam, 2006.

CHIAVENATO, Idalberto. Introdução à Teoria Geral da Administração. $7^{\text {a }}$ edição. Rio de Janeiro: Elsevier, 2003.

DICIONÁRIO DO COMÉRCIO EXTERIOR. SERPRO. Brasília, 2010. Disponível em: < http://www.glossarioce.serpro.gov.br/pagina.php>. Acesso em: 20 jun. 2010.

Estatísticas do Fórum Internacional do Transporte. Disponível em: < http://www.internationaltransportforum.org/statistics/statistics.html>. Acesso em 14 jun. 2010.

FERREIRA, Aurélio B. de Holanda. Dicionário da Língua Portuguesa. 4. edição. Rio de Janeiro: Nova Fronteira, 2000.

FGV/CPDOC. A Era Vargas: dos anos 20 a 1945. Disponível em:

<http://cpdoc.fgv.br / producao/dossies/AEraVargas1/apresentacao>. Acesso em 15 jul. 2010. 
FIÚZA, Eduardo P. S.; PIONER; Heleno Martins. Concorrência no Setor de Aeroportos. V. 2. Rio de Janeiro: ANAC, 2009. Disponível em:

<http://www.anac.gov.br/arquivos/pdf/Volume_Completo2.pdf>. Acesso em: 11 jul. 2010.

FLEURY, P. F.; WANKE, PETER; FIGUEIREDO, K. F.; (orgs). Logística

Empresarial: a perspectiva brasileira. São Paulo: Atlas, 2003.

GOMES, Carlos F. Simões; RIBEIRO, Priscila C. Cabral. Gestão de cadeia de suprimentos integrada a tecnologia da informação. São Paulo: Pioneira Thomson Learning, 2004.

HARRISON, Alan; HOEK, Remko Van. Estratégia e gerenciamento de logística. tradução Bazán Tecnologia e Lingüística. São Paulo: Fututa, 2003.

ICAO - INTERNATIONAL CIVIL AVIATION ORGANIZATION (Montreal, Canadá). Relatório Anual do Conselho. 2010. Disponível em: <http://www.icao.int/ annualreports>. Acesso em 18 jun. 2010.

INFRAERO (Brasília, DF). Relatórios do sistema TECAPLUS. Brasilia, 2010.

INFRAERO (Brasília, DF). Sistemas OPNET e SIGCA. In: Infranet. Brasília, 2010.

INFRAERO (Brasília, DF).Tarifas Aeroportuárias e de Navegação Aérea. Brasilia, 2010. 29 p. Disponível em: <http://www.INFRAERO.gov.br/upload/arquivos/inst/ TarifPortapr2010.pdf>. Acesso em: 27 jul. 2010.

INTERNATIONAL TRANSPORT FORUM, 1993. In: Logpro: Portal do Conhecimento em Logística. Rio de Janeiro, 2010. Disponível em: <

http://www.logpro.com.br/logpro/IntermodalidadeeMultimodalidade.asp> .Acesso em: 22 jun. 2010.

IPEA (Brasília, DF). Aviação Regional Começa a Crescer. Brasília: Presidência da República, 2010. Disponível em: http://www.ipea.gov.br/portal/index.php?option= com_content\&view=article\&id=1356:aviacao-regional-brasileira-comeca-acrescer\&catid=4:presidencia\&Itemid=2. Acesso em: 20 jul. 2010.

JÚNIOR, A. G. Armando. Transportes Internacionais de Mercadorias e Pessoas no Mercosul. $1^{a}$ Ed. São Paulo: Aduaneiras, 2002.

KASARDA, John D. Airport Cities. Disponível em: <http://www.aerotropolis.com/ aerotropolis.html >. Acesso em 15 jun. 2010. 
KAUFMANN, G. Oliveira. Transporte Aéreo de Carga: análise do setor e das tecnologias utilizadas. Monografia (bacharelado em Administração). Universidade de Brasília, Brasília, 2009. p. 51-54..

KEEDI, Samir. ABC do Comércio exterior. 2. ed. São Paulo: Aduaneiras, 2005.

KWASNICKA, E. Lacava. Introdução à Administração. $5^{a}$ Ed. São Paulo: Atlas, 1995.

MAIA, Jayme de Moriz. Economia Internacional e Comercio Exterior. 5. ed. São Paulo: Atlas, 1999.

MALERBA, Franco. Sectoral Systems of Innovation: Concepts, issues and analyses of six major sectors in Europe. New York: Cambridge University Press, 2004.

MANUAL DE EXPORTAÇÃO. FIESP. São Paulo: SENAI, 2004. Disponível em: $<$ http://www.fiesp.com.br/publicacoes/pdf/relacoes/manual_exportacao.pdf $>$. Acesso em: 20 jun. 2010.

MANUAL DE IMPORTAÇÃO DA UNIVERSIDADE ESTADUAL PAULISTA. São Paulo: UNESP, 2003. Disponível em: <http://www.unesp.br/prad/importacao/manualimportacao.pdf.> Acesso em 19 jun. 2010.

MARTINS, Petrônio Garcia; LAUGENI, Fernando P. Administração da Produção. 2. ed. São Paulo: Saraiva, 2005.

MATOS, João R. Loureiro de; GUIMARÃES, Leonam dos Santos. Gestão da Tecnologia e Inovação: uma abordagem prática. São Paulo: Saraiva, 2006.

MDIC (Brasília, DF). Balança comercial por Unidade da Federação. Brasília, 2010. Disponível em: <http://www.mdic.gov.br/sitio/interna/ interna. php?area=5\&menu= 1078\&refr=1076>. Acesso em: 03 ago. 2010.

MOURA, Benjamin do Carmo. Logistica Conceitos e Tendência. Lisboa: Centro Atlântico, 2006.

O GLOBO. SEÇÃO ECONOMIA. Principais aeroportos brasileiros não conseguem atender à demanda, diz IPEA. Disponível em:

<http://oglobo.globo.com/economia/mat/2010/05/31/principais-aeroportos-brasileirosnao-conseguem-atender-demanda-diz-ipea-916739828.asp> . Acesso em 20 jun. 2010. 
OLIVEIRA, Daniele Silva. Estudo do Desempenho dos Aeroportos Brasileiros relativo ao Movimento de Cargas. Instituto Tecnológico de Aeronáutica. São Jose dos Campos, 2007.

REIS, Dálcio Roberto dos. Gestão da Inovação Tecnológica. Barueri, São Paulo: Manole, 2004.

RESENDE, P. T. V.; CYRINO, Alvaro Bruno; RICUPERO, Rubens. Gerenciamento Global das Cadeias de Suprimentos. In: André Almeida. (Org.). Internacionalização de Empresas Brasileiras. 1. ed. Rio de Janeiro: Campus / Elsevier, 2007, v. 01, p. 191-238.

REVERSE LOGISTICS GLOSSARY. Disponível em: <http://www.rlec.org/ glossary.html>. Acesso em: 16 JUN. 2010.

SCAVARDA, Luiz Felipe; FILHO, Cícero Nogueira; KRAEMER, Victor. RFID na Logística: Fundamentos e Aplicações. In: XXV ENCONTRO NACIONAL DE ENGENHARIA DE PRODUÇÃO, 25., 2005, Porto Alegre. Anais...Rio de Janeiro: PUC, 2004. p. 4-7.

SILVA, Adyr. Aeroportos e Desenvolvimento. 1. ed. Belo Horizonte: Vila Rica, 1991.

SKYSCRAPERCITY. Fórum AIJK, 2010. Projeção da ampliação do Aeroporto de Brasília. Disponível em: <http://www.skyscrapercity.com/showthread.php? $\mathrm{t}=404892 \&$ page $=52>$. Acesso em: 25 jul. 2010.

SNEA (Brasília, DF). Análise Setorial do SNEA - Carga. 2009. Disponível em: <http://www.snea.org.br/images/Estudos>. Acesso em 18 jun. 2010.

SOUZA, Cláudio Luiz Gonçalves de. Roteiro prático de Exportação e Importação: Sistema Básico Operacional. Belo Horizonte: Líder, 2003.

STEVENSON, Willian J. Administração das operações de produção. Rio de Janeiro: LTC, 2001.

TAM LINHAS AÉREAS S/A. Informações Importantes.Disponível em: <http://www.tamcargo.com.br ste/jsp/default.jhtml ?adPagina=459\&adArtigo=2756> Acesso em: 10 jul. 2010.

TAYLOR, David A. Logística na Cadeia de Suprimentos: Uma Perspectiva Gerencial. São Paulo: Pearson Addison - Wesley, 2005. 
TIACA - INTERNATIONAL AIR CARGO ASSOCIATION (Flórida, USA). Previsões do Mercado de Carga. Disponível em: <http://www.tiaca.org/tiaca/Forecast.asp? SnID=1393137695>. Acesso em: 17 jun. 2010.

TIACA, 2010. In: Air Cargo Forum: Papers, 13 set. 2006. Calgary Canadá, 2006.

Disponível em: < http://www.tiaca.org/tiaca/Papers1.asp?SnID =1538722539>.

Acesso em: 15 jun. 2010.

VASCONCELOS, Leonardo Fernandes Soares. O Aeroporto como Integrante de um Projeto de Desenvolvimento Regional: A Experiência Brasileira. Dissertação de Mestrado em Transportes. Universidade de Brasília. Brasília, 2007.

VIEIRA, G. B. Borges. Transporte Internacional de Cargas. 2. Ed. São Paulo: Aduaneiras, 2002.

WAPEDIA. ENCICLOPÉDIA MÓVEL. Aeroporto Internacional de Brasília. Disponível em: <http://wapedia.mobi/pt/Aeroporto_Internacional_de_Bras $\%$ C3\%ADlia> Acesso em: 11 jul. 2010 


\title{
APÊNDICE A - Roteiro de Entrevista Dirigida
}

\author{
ROTEIRO DE ENTREVISTA APLICADA AOS GESTORES DO AEROPORTO \\ INTERNACIONAL DE BRASÍLIA PRESIDENTE JUSCELINO KUBITSCHEK \\ (AIB-PJK) - ATIVIDADE DE LOGÍSTICA DE CARGA AÉREA
}

\section{Sobre a entrevista:}

Esta entrevista tem como objetivo complementar a presente pesquisa acadêmica de conclusão do curso de Bacharelado em Administração de Empresas pela Universidade de Brasília-UNB, na área temática de transporte e logística, com o objetivo de obter informações qualitativas relevantes, opiniões, sugestões e inshigts dos gestores que desempenham atividades no Aeroporto Internacional de BrasíliaDF, para analisar o papel da Empresa Brasileira de Infraestrutura Aeroportuária INFRAERO na cadeia logística de carga aérea do Distrito Federal.

\section{População e amostra:}

Foram entrevistados 10 funcionários que exercem cargos de Confiança ligados diretamente a atividade de Logística de Carga do AIB, sendo eles o Superintende do AIB, o Gerente de Logística, o Coordenador de Importação e Exportação, o Coordenador de Carga Nacional, o Coordenador de Facilitação e Atendimento ao Cliente, 04 Encarregados de Atividade de TECA, e o Coordenador de Logística de Carga da Superintendência Regional do Centro-Oeste, correspondendo uma amostra de $91 \%$ da população.

\section{ROTEIRO DA ENTREVISTA}

\section{Variável I: Demanda da Carga Aeroportuária no Aeroporto de Brasília}

Pergunta 01: Como avalia a logística de carga nacional no AIB-PJK? Como está evoluindo nos últimos anos em termos financeiros e de infraestrutura? Existem pontos a serem melhorados?

Pergunta 02: Como avalia a logística de carga internacional no AIB-PJK? Como está evoluindo nos últimos anos em termos financeiros e de infraestrutura? Existem pontos a serem melhorados? 
Pergunta 03: Existe potencial de mercado de cargas a ser explorado para o aeroporto na atual conjuntura?

\section{Variável II: Inovação Setorial Aeroportuária}

Pergunta 04: Na sua opinião a infraestrutura tecnológica do TECA-BR é moderna? Quais investimentos seriam necessários para torná-la mais competitiva?

Pergunta 05: Em relação ao sistema de informação gerencial TECAPLUS, qual sua opinião em relação à adequação operacional do sistema e quais melhorias poderiam ser desenvolvidas, caso necessárias?

Pergunta 06: No que diz respeito aos relatórios gerenciais da logística de carga, estes retratam com eficiência a atividade, abordando todos os elementos necessários para análises financeiras, operacionais e de mercado?

\section{Variável III: Manuseio, guarda e desembaraço da Carga no TECA-BR}

Pergunta 07: Quais são os pontos considerados críticos na atividade de recepção, armazenagem e despacho de carga no AIB-PJK, e como podem ser melhorados, caso existirem?

Pergunta 08: Como está fluindo as informações entre os órgãos anuentes, INFRAERO e demais stakeholders (despachantes, agentes de carga e clientes)? Está existindo a celeridade dos processos e produtividade dos armazéns? Como é a relação entre estes agentes.

\section{Variável IV: Integração das Atividades Aeroportuárias do DF}

Pergunta 09: Quais são as suas expectativas em relação à construção do novo Terminal de Passageiros - TPS do AIB-PJK e principalmente do novo Terminal de Cargas? Em sua opinião é necessário aumentar a capacidade do Terminal de Cargas do Aeroporto de Brasília?

Pergunta 10: Com os planos de investimento na infraestrutura aeroportuária brasileira pelo Programa de Aceleração do Crescimento - PAC, para os próximos anos, e os mega-eventos como a Copa do Mundo e Olimpíadas, que implicação têm esses investimentos neste aeroporto? Seria justificável a ampliação do aeroporto? 
Variável V: Concorrentes das Atividades Aeroportuárias no DF

Pergunta 11: Como avalia a concorrência existente, no âmbito do sítio aeroportuário, no que diz respeito a armazenagem de cargas domésticas e internacionais. Existe influência da iniciativa privada no que diz respeito à administração aeroportuária?

Pergunta 12: Como avalia a privatização dos aeroportos brasileiros? Quais seriam os impactos no âmbito organizacional da INFRAERO? 


\section{APÊNDICE B - Relação dos Respondentes da Entrevista Dirigida}

\begin{tabular}{|l|c|c|c|}
\hline \multicolumn{1}{|c|}{ NOME } & CARGo & $\begin{array}{c}\text { TEMPO } \\
\text { NA } \\
\text { EMPRESA }\end{array}$ & $\begin{array}{c}\text { TEMPO EM } \\
\text { FUNÇÃO DE } \\
\text { CONFIANÇA }\end{array}$ \\
\hline Aerolino Neto & $\begin{array}{c}\text { Encarregado de } \\
\text { Atividade TECA }\end{array}$ & 09 anos & 07 meses \\
\hline Antonio Erivaldo Sales & Superintendente SBBR & 27 anos & 15 anos \\
\hline Arthur de Castro Soares & $\begin{array}{c}\text { Coordenador de Carga } \\
\text { Internacional }\end{array}$ & $\begin{array}{c}05 \text { anos e } \\
07 \text { meses }\end{array}$ & 02 anos e 06 meses \\
\hline Lázaro Romualdo da Silva & $\begin{array}{c}\text { Encarregado de } \\
\text { Atividade TECA }\end{array}$ & 10 anos & 01 ano e 04 meses \\
\hline Luzia Dias da Silva & $\begin{array}{c}\text { Encarregado de } \\
\text { Atividade TECA }\end{array}$ & $\begin{array}{c}02 \text { anos e } \\
03 \text { meses }\end{array}$ & 05 meses \\
\hline Marcos F. Ferreira Trindade & $\begin{array}{c}\text { Gerente de Logística } \\
\text { SBBR }\end{array}$ & 31 anos & 06 anos \\
\hline Miguel F. Rodrigues Santiago & $\begin{array}{c}\text { Coordenador de Carga } \\
\text { Nacional }\end{array}$ & 10 anos & 01 ano e 05 meses \\
\hline Nilson de Melo Teixeira & $\begin{array}{c}\text { Coord. de Logística da } \\
\text { Sup. Regional }\end{array}$ & 10 anos & 05 anos \\
\hline Rafael Crispim Vergine & $\begin{array}{c}\text { Encarregado de } \\
\text { Atividade TECA }\end{array}$ & $\begin{array}{c}05 \text { anos e } \\
05 \text { meses }\end{array}$ & 02 anos \\
\hline Renato Leite Shimidt & $\begin{array}{c}\text { Coord. de } \\
\text { Facilitação e Atend. } \\
\text { ao Cliente }\end{array}$ & 13 anos & 02 anos e 05 meses \\
\hline Obs: apenas um indivíduo, um dos Encarregados de Atividades, não foi entrevistado. \\
\hline
\end{tabular}


APÊNDICE C - Organograma da Superintendência do AIB-PJK

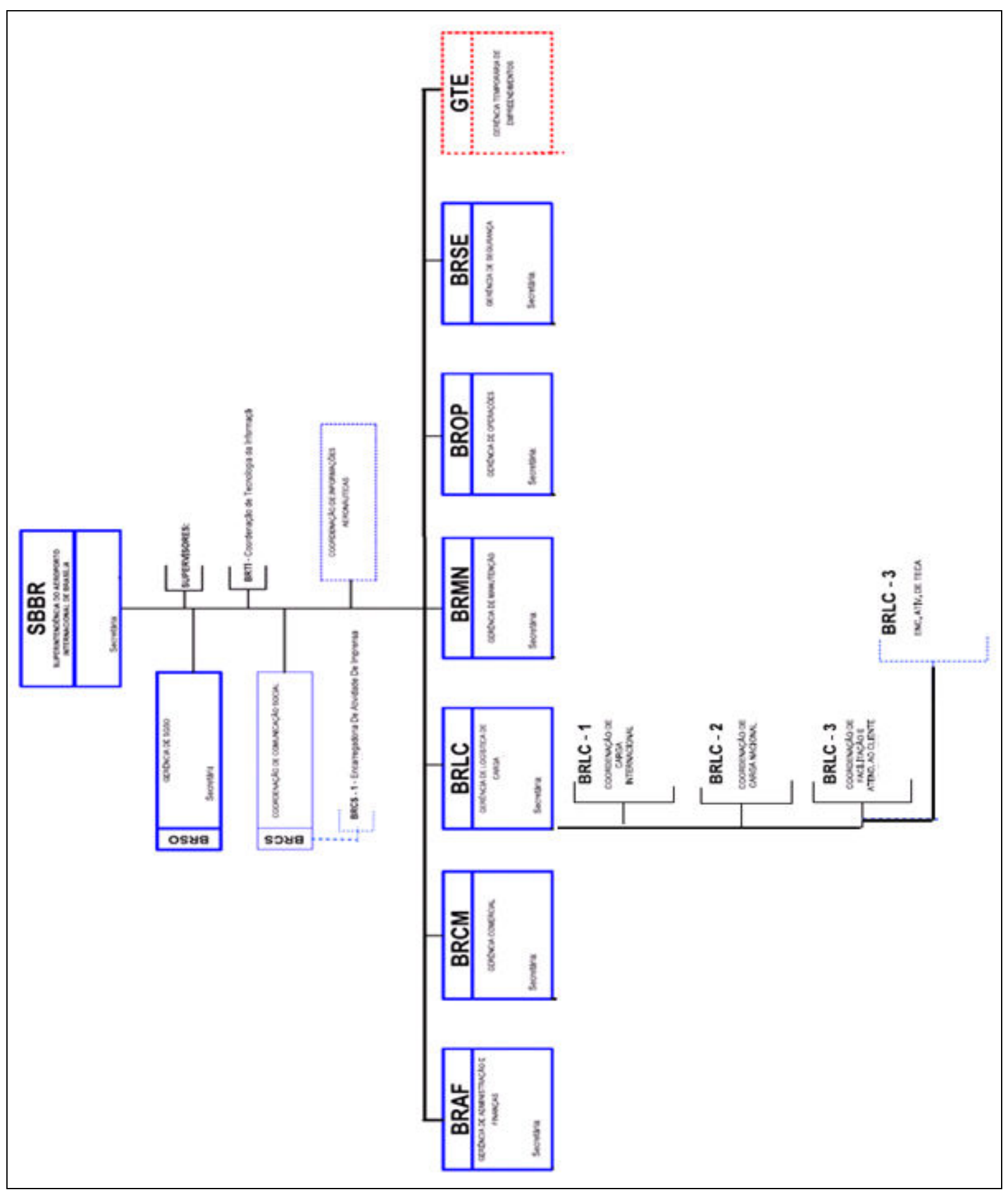

Fonte: Adaptado de SGQI. INFRAERO, 2010. 
APÊNDICE D - PERSPECTIVA AÉREA DA AMPLIAÇÃO DO AIB-PJK

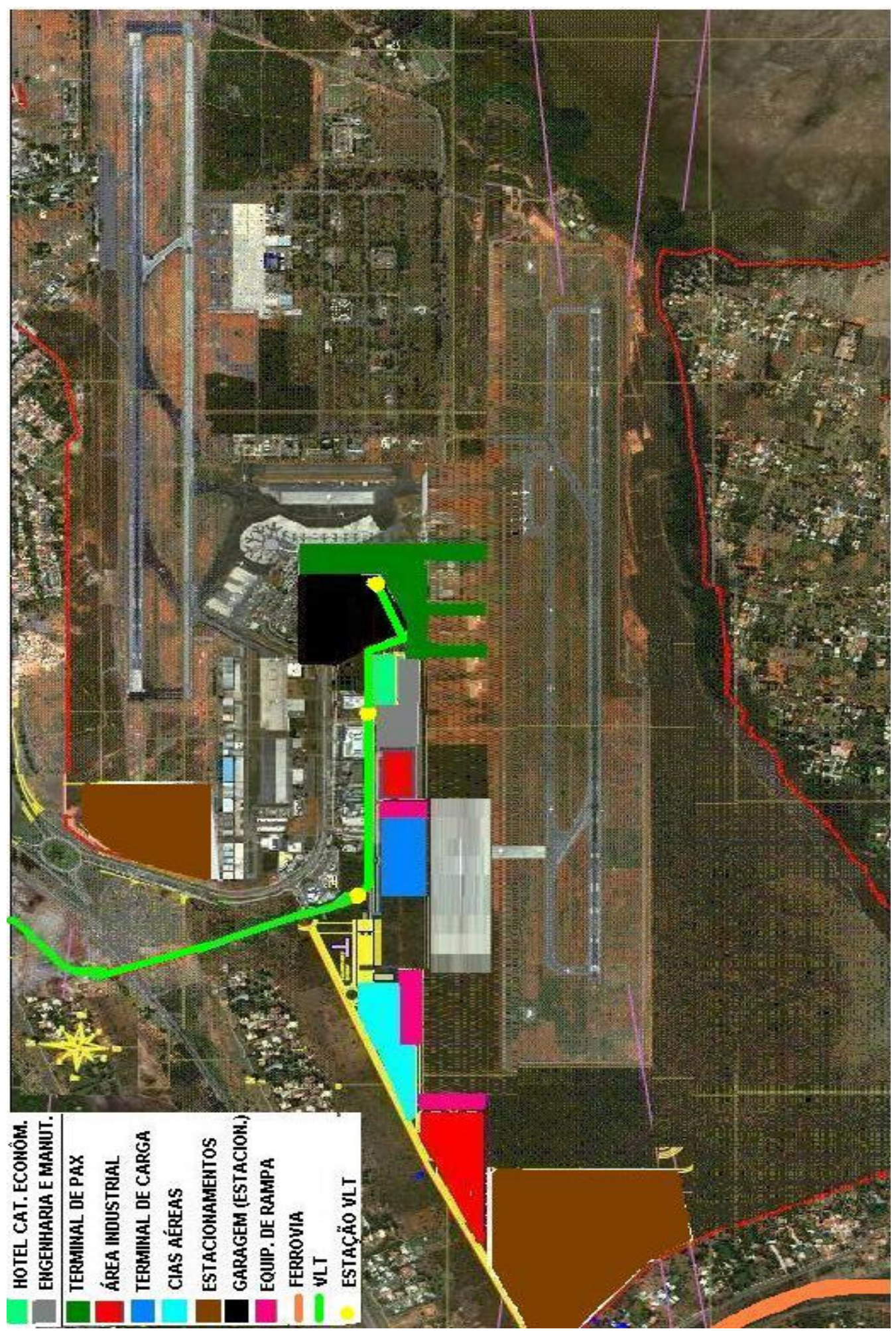

Fonte: Adaptado de INFRAERO 2010. 


\section{ANEXO A - TABELA DE TARIFAS DE ARMAZENAGEM}

\section{TABELA 1}

Preço relativo à Tarifa Aeroportuária de Armazenagem de carga importada

\begin{tabular}{|c|c|}
\hline PERÍODOS DE ARMAZENAGEM & PERCENTUAL SOBRE O VALOR CIF \\
\hline $1^{\circ}$ - Até 5 dias úteis & $1,0 \%$ \\
\hline $2^{\circ}-$ De 6 a 10 dias úteis & $1,5 \%$ \\
\hline $3^{\circ}$ - De 11 a 20 dias úteis & $3,0 \%$ \\
\hline $\begin{array}{c}\text { Para cada } 10 \text { dias úteis ou fração, além do } \\
3^{\circ} \text { período, até a retirada da mercadoria }\end{array}$ & $+1,5 \%$ \\
\hline
\end{tabular}

\section{Observações:}

1. A partir do $3^{\circ}$ período, os percentuais são cumulativos; e

2. Esta Tabela é aplicada cumulativamente com a Tabela 2.

3. Valores não acrescidos do ADICIONAL TARIFÁRIO DE 50\%.

\section{TABELA 2}

Preço relativo à Tarifa Aeroportuária de Capatazia de carga importada

\section{SOBRE O PESO BRUTO VERIFICADO}

US $\$ 0,015$ por quilograma

\section{Observações:}

1. Esta Tabela é aplicada cumulativamente com a Tabela 1;

2. O valor da Tarifa Aeroportuária de Capatazia será cobrado uma única vez; e cobrança mínima, US\$ 5.00 (cinco dólares).

3. Valores não acrescidos do ADICIONAL TARIFÁRIO DE 50\%.

\section{TABELA 3}

Preço cumulativo relativo às Tarifas Aeroportuárias de Armazenagem e de Capatazia da carga importada ou em trânsito 


\begin{tabular}{|c|c|}
\hline PERÍODO DE ARMAZENAGEM & $\begin{array}{c}\text { SOBRE O PESO } \\
\text { BRUTO } \\
\text { VERIFICADO }\end{array}$ \\
\hline $1^{\circ}$ - Até 4 dias úteis & $\begin{array}{c}\text { US\$ 0,04 por } \\
\text { quilograma }\end{array}$ \\
\hline $\begin{array}{c}2^{\circ} \text { - Para cada 2 dias úteis ou fração, além do } 1^{\circ} \\
\text { período, até a retirada da mercadoria }\end{array}$ & $\begin{array}{c}\text { US } 0,04 \text { por } \\
\text { quilograma }\end{array}$ \\
\hline
\end{tabular}

A Tarifa mínima a ser cobrada, será correspondente a US $\$ 5.00$ (cinco dólares); Esta Tabela será aplicada em casos específicos: disponível em: http://www.INFRAERO.gov.br/upload/arquivos/inst/TarifPortapr2010.pdf (pag. 27).

Preço relativo à Tarifa Aeroportuária de Capatazia de Carga importada sob regime especial de trânsito aduaneiro simplificado destinado a recinto alfandegado localizado na zona secundária.

\begin{tabular}{|c|}
\hline SOBRE O PESO BRUTO VERIFICADO \\
\hline US\$ 0,25 por quilograma \\
\hline
\end{tabular}

OBS:

a) Cobrança mínima, US\$25,00 (vinte e cinco dólares);

b) Esta Tabela aplica-se à carga com permanência máxima de 24 (vinte e quatro) horas

no TECA; e

c) Excedido o prazo de 24 (vinte quatro) horas, após a entrada da carga no TECA, deverão ser aplicadas as Tabelas 1 e 2 ou a Tabela 5 desta Portaria.

d) Valores não acrescidos do ADICIONAL TARIFÁRIO DE 50\%.

\section{TABELA 5}

Preço cumulativo das Tarifas Aeroportuárias de Armazenagem e de Capatazia de carga importada de alto valor específico

\begin{tabular}{|c|c|c|}
\hline $\begin{array}{c}\text { PERIOODOS DE } \\
\text { ARMAZENAGEM }\end{array}$ & FAIXA & $\begin{array}{c}\text { PERCENTUAL } \\
\text { SOBRE O VALOR } \\
\text { CIF }\end{array}$ \\
\hline & De: US\$2.500,00/kga US\$ & $0,4 \%$ \\
\hline
\end{tabular}




\begin{tabular}{|c|c|c|}
\hline \multirow{3}{*}{$\begin{array}{c}3 \text { dias úteis ou fração, } \\
\text { a contar da data do } \\
\text { recebimento no TECA }\end{array}$} & $9.999,99 / \mathrm{kg}$ & \\
\hline & $\begin{array}{c}\text { De: US\$ } 10.000 .00 / \mathrm{kg} a \\
\text { US\$ } 39.999,99 / \mathrm{kg}\end{array}$ & $0,2 \%$ \\
\hline & $\begin{array}{c}\text { Acima de: US\$ 40.000,00 / } \\
\text { kg }\end{array}$ & $0,1 \%$ \\
\hline
\end{tabular}

\section{Observações:}

1. O valor CIF por quilograma tem como referencial para cálculo o peso líquido da carga.

2. Valores não acrescidos do ADICIONAL TARIFÁRIO DE 50\%.

Fonte: www.infraero.gov.br 
ANEXO B - COTAÇÃO DO DÓLAR : 2005 À 2009

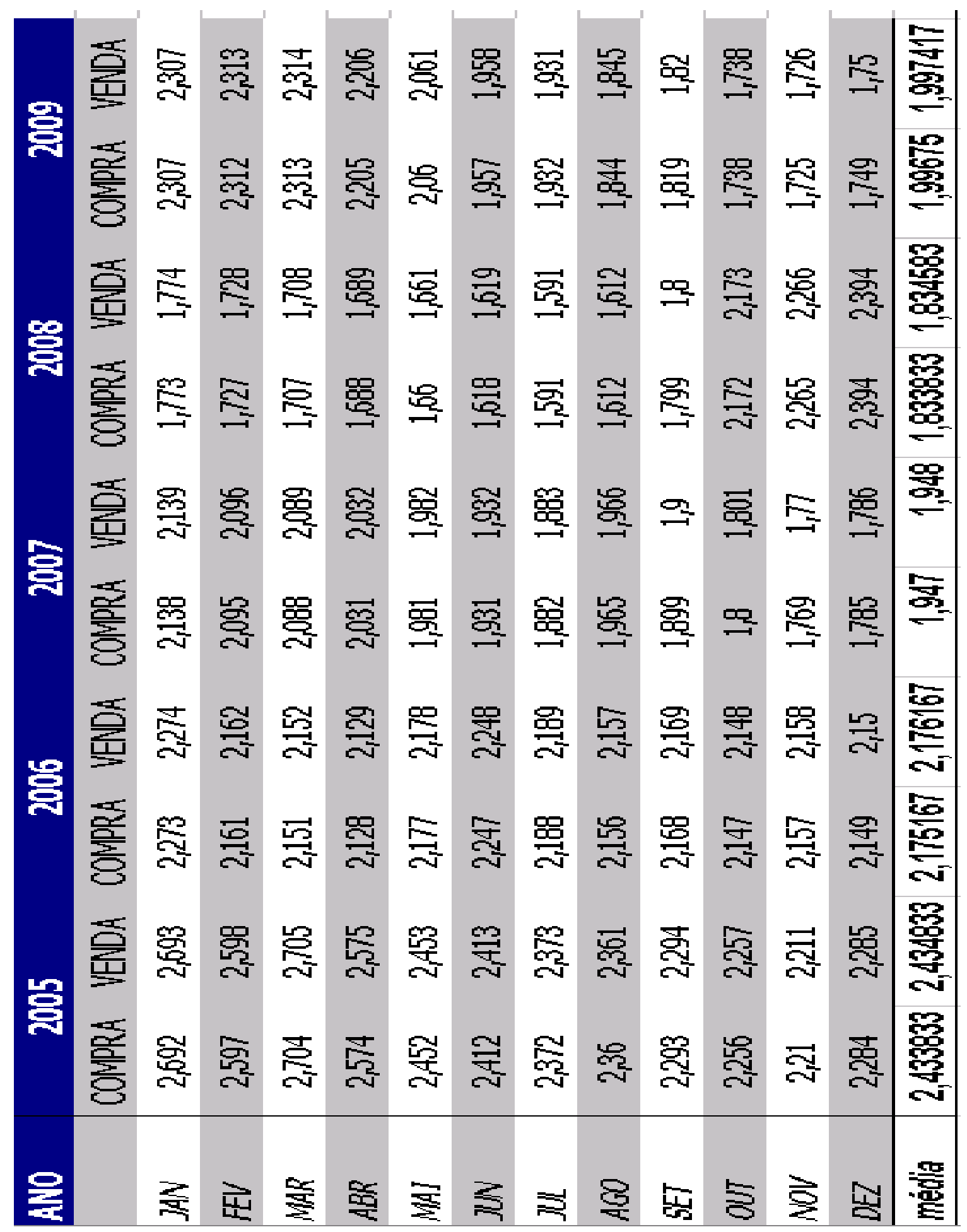

Fonte: http://www.acinh.com.br/cotacao.asp. Adaptado de Banco Central do Brasil 